\title{
Online flow measurement in hemodialysis vascular access
}

Citation for published version (APA):

Wijnen, E. (2010). Online flow measurement in hemodialysis vascular access. [Doctoral Thesis, Maastricht University]. Datawyse / Universitaire Pers Maastricht. https://doi.org/10.26481/dis.20100603ew

Document status and date:

Published: 01/01/2010

DOI:

10.26481/dis.20100603ew

Document Version:

Publisher's PDF, also known as Version of record

\section{Please check the document version of this publication:}

- A submitted manuscript is the version of the article upon submission and before peer-review. There can be important differences between the submitted version and the official published version of record.

People interested in the research are advised to contact the author for the final version of the publication, or visit the DOI to the publisher's website.

- The final author version and the galley proof are versions of the publication after peer review.

- The final published version features the final layout of the paper including the volume, issue and page numbers.

Link to publication

\footnotetext{
General rights rights.

- You may freely distribute the URL identifying the publication in the public portal. please follow below link for the End User Agreement:

www.umlib.nl/taverne-license

Take down policy

If you believe that this document breaches copyright please contact us at:

repository@maastrichtuniversity.nl

providing details and we will investigate your claim.
}

Copyright and moral rights for the publications made accessible in the public portal are retained by the authors and/or other copyright owners and it is a condition of accessing publications that users recognise and abide by the legal requirements associated with these

- Users may download and print one copy of any publication from the public portal for the purpose of private study or research.

- You may not further distribute the material or use it for any profit-making activity or commercial gain

If the publication is distributed under the terms of Article $25 \mathrm{fa}$ of the Dutch Copyright Act, indicated by the "Taverne" license above, 


\section{Online flow measurement in hemodialysis vascular access}


(C) 2010 Edwin Wijnen, Maastricht

Layout: Tiny Wouters

Production: Datawyse | Universitaire Pers Maastricht

ISBN: 978-90-5278-941-5

Financial support for the printing of this thesis was kindly provided by: Fresenius Medical Care Nederland B.V., Nipro Europe N.V., Baxter B.V., Transonic Systems Europe B.V., Roche Nederland B.V., Shire Benelux, Bard Benelux N.V., Abott B.V. and Genzyme Europe B.V.. 


\title{
Online flow measurement in hemodialysis vascular access
}

\author{
PROEFSCHRIFT
}

ter verkrijging van de graad van doctor aan de Universiteit Maastricht, op gezag van de Rector Magnificus, Prof. mr. G.P.M.F. Mols, volgens het besluit van het College van Decanen, in het openbaar te verdedigen op donderdag 3 juni 2010 om 14:00 uur

door

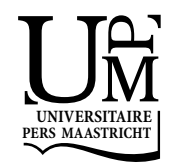


Promotor:

Prof. dr. K.M.L. Leunissen

\section{Copromotores:}

Dr. F.M. van der Sande

Dr. J.H.M. Tordoir

\section{Beoordelingscommissie:}

Prof. dr. L. Hofstra (voorzitter)

Dr. M.R. Scheltinga, Maxima Medisch Centrum, Veldhoven

Prof. dr. G.J. van der Vusse

Prof. dr. P.M. ter Wee, VUmc, Amsterdam 
Aan: Mijn ouders

Voor: Linda, Simon en Sofie 



\section{Contents}

Abbreviations

Chapter 1 Introduction

Chapter 2 Impact of a quality improvement program based on vascular access flow monitoring on costs, access occlusion and access failure

Chapter 3 Effect of online haemodialysis vascular access flow evaluation and pre-emptive intervention on the frequency of access thrombosis

Chapter 4 Comparison between two on-line reversed line position haemodialysis vascular access flow measurement techniques; saline dilution and thermodilution

Chapter 5 Measurement of hemodialysis vascular access flow using extracorporeal temperature gradients

Chapter 6 Vascular access recirculation: setting a new detection method in the context of the overall utility of detection. Commentary

Chapter 7 The relation between vascular access flow and different types of vascular access with systemic hemodynamics in hemodialysis patients

Chapter 8 General discussion

Summary

Samenvatting

Dankwoord

Curriculum Vitae 



\section{Abbreviations}

$\begin{array}{ll}\text { AVF } & \text { arteriovenous fistula } \\ \text { AVG } & \text { arteriovenous graft } \\ \text { BTM } & \text { blood temperature monitor } \\ \text { CBV } & \text { central blood volume } \\ \text { CBVI } & \text { central blood volume index } \\ \text { CI } & \text { cardiac index } \\ \text { CO } & \text { cardiac output } \\ \text { CPR } & \text { cardiopulmonary recirculation } \\ \text { DSA } & \text { digital subtraction angiography } \\ \text { ESRD } & \text { end stage renal disease } \\ \text { IH } & \text { intimal hyperplasia } \\ \text { MRI } & \text { magnetic resonance imaging } \\ \text { NS } & \text { not significant } \\ \text { NYHA } & \text { New York Heart Association } \\ \text { PD } & \text { peritoneal dialysis } \\ \text { PTA } & \text { percutaneous transluminal angioplasty } \\ \text { PVR } & \text { peripheral vascular resistance } \\ \text { Qa } & \text { vascular access flow in ml/min } \\ \text { Qb } & \text { extracorporeal blood pump speed in } \mathrm{ml} / \mathrm{min} \\ \text { QIP } & \text { quality improvement period } \\ \text { R } & \text { recirculation } \\ \text { RP } & \text { reference period } \\ \text { SD } & \text { standard deviation } \\ \text { TGM } & \text { remperature gradient method } \\ \Delta \text { Xrel } & \end{array}$



Chapter 1

Introduction 


\section{Renal failure and principles of hemodialysis}

A healthy kidney is responsible for a continuous balance of the milieu interior through volume and electrolyte control, excretion of waste products, maintenance of the acid/base balance, and production of hormones.

In patients with end-stage renal disease (ESRD) these functions are impaired. Renal hormonal functions can, for the larger part, be substituted through medication, the other functions have to be substituted through renal replacement therapy. Besides transplantation, the two major treatment modalities are peritoneal dialysis (PD) and hemodialysis (HD).

Dialysis is the process of separating elements in a solution by diffusion across a semipermeable membrane down a concentration gradient. This is the principal process for substitution of the renal function.

The basis of $P D$ is that the peritoneum functions as a semipermeable membrane: through a catheter positioned in the peritoneal cavity, a sterile fluid is infused which causes a passive exchange of toxins and water from the peritoneal capillaries into the peritoneal cavity. This treatment is ideal for some patients who still have some residual renal function. However, the major part of ESRD patients relay on HD. Worldwide 1.222.000 ESRD patients are treated with HD, compared to 149.000 patients with PD ${ }^{1}$. The semipermeable membrane used with HD is an artificial kidney. The artificial kidney is integrated in an extracorporeal tubing system. A vascular access is used to connect the tubing system to the patients' circulation. An occlusive pump creates a continuous blood flow through the extracorporeal system. The blood passes the artificial kidney and returns to the patient. During the artificial kidney passage, diffusion takes place between the blood and a sterile dialysate fluid which contains electrolytes and bicarbonate for acidosis correction (Figure 1.1).

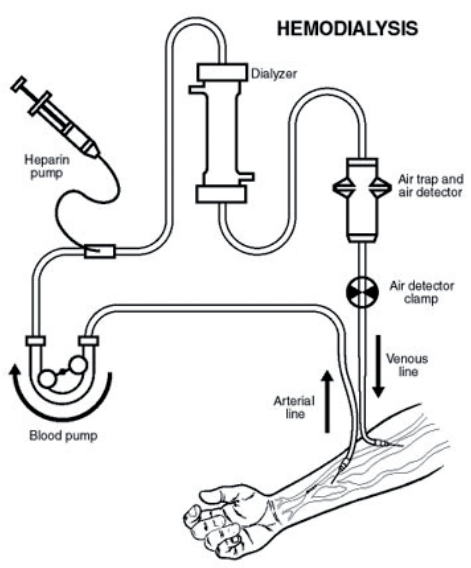

Figure 1.1 Hemodialyses treatment setup. 
By creating a negative pressure over the artificial kidney membrane it is possible to correct fluid retention. The average HD treatment time is three to four hours, and takes place with a frequency of three times a week.

\section{Hemodialysis and types of vascular access}

The vascular access is often referred to as being the Achilles heel of HD: In order to achieve efficient cleansing, the blood has to be drained from the patient with an average of 300 to $400 \mathrm{ml} / \mathrm{min}$, resulting in a total of 70 to 90 liters of blood passing the artificial kidney during one HD treatment. It is evident that $\mathrm{HD}$ requires a safe, reliable, high efficient, multiple accessible vascular access that offers a high flow.

\section{Radiocephalic fistula}

Pioneers in renal replacement therapy and HD had their first breakthroughs in the 1940 's ${ }^{2,3}$ and already in the 1950s technical devices were available for regular HD treatments. But not until 1966, the above described durable and reliable access to the patients' circulation, had been invented by Brescia, Cimino, and Appel ${ }^{4}$. Their idea of creating a radio cephalic fistula, is still the first choice of vascular access.

The created low resistance causes an increase in flow through the artery and the vein, the vein diameter enlarges, and the vein vessel wall thickens. This vascular access is less sensitive for infection because of the subcutaneous position. It has a relatively low complication rate and a long life expectancy ${ }^{5}$, has minor impact on patients daily life, is easy to cannulate for each HD treatment (efficient and multiple accessible), and generates a high flow.

However, due to recent trends in patient demographics the construction of this ideal vascular access is often not possible. Since the 1990s, proportional with the improvement of HD techniques and HD treatment in general, there is a steady increase in the incidence of renal replacement therapy in developed countries. This increase has been manifested especially among elderly patients (Figure 1.2) and in particular for ESRD associated with diabetes mellitus $(D M)^{6-9}$, peripheral arterial obstructive disease (PAOD) or coronary artery disease. Many of these patients have poor vessels for construction of the above described radio cephalic fistula ${ }^{10}$. 


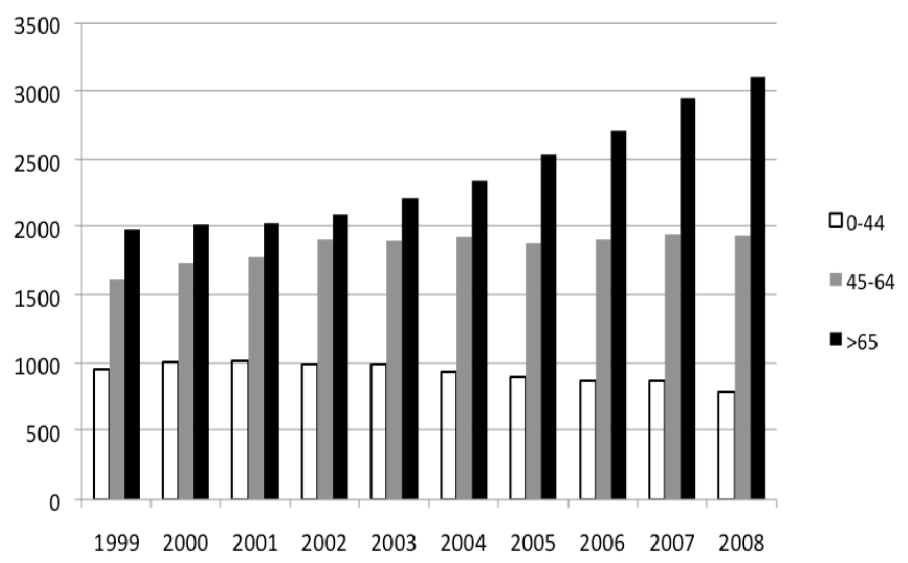

Figure 1.2 Total incidences of ESRD patients in the Netherlands by age groups in the period 1999-2008 (source: renine stichting).

\section{Brachial-cubital, cephalic and basilic fistula}

Upper arm fistulae are an important alternative for compromised patients. When peripheral vessels are too tiny and diseased for the creation of a radiocephalic fistula, upper arm AVF may be indicated ${ }^{11,12}$. The brachial artery is either anastomosed to the cubital, cephalic or basilic vein.

Primary and secondary patency of upper arm fistula are comparable to those of radiocephalic fistulae or even better ${ }^{13,14}$. However, upper arm fistulae are known for generating excessive high access flows, due to the use of a larger feeding (brachial) artery and the more proximal location of the access to the heart ${ }^{15,16}$. An absolute flow of $1500 \mathrm{ml} / \mathrm{min}$ is generally considered a high access flow, but should in fact be related to cardiac output $(\mathrm{CO}, \mathrm{L} / \mathrm{min})^{17}$. Several studies found a relation between access flow and $\mathrm{CO}^{18-22}$. Excessive high access flow (sometimes up to $40 \%$ of $\mathrm{CO}^{19}$ ) causes disturbed systemic hemodynamics, and may result in heart failure.

High access flow may also cause peripheral circulatory complications. When the created low resistance causes insufficient blood supply distal to the access this results in ischemia (Steal syndrome) ${ }^{23}$. If not detected and treated in time, amputation may be unavoidable.

\section{Arteriovenous graft}

An arteriovenous graft can be of biologic or synthetic material; however, synthetic grafts are utilized most frequently. The graft material is implanted subcutaneously into either the fore or upper arm, but the chest or leg area may be used as well. An AVG is 
anastomosed to an artery and a vein. It can be used within two weeks after implantation and is easy to cannulate.

However, AVG stenosis formation (mostly at the graft-vein anastomoses) will lead to thrombotic occlusion within 12 to 24 months $^{24}$. Intimal hyperplasia $(\mathrm{IH})$ with smooth muscle cell migration and proliferation and matrix deposition is the major cause for stenosis formation and thrombosis. The etiology of $\mathrm{IH}$ is unknown, however, high shear stress due to the unnatural high flow causing turbulent instead of laminar flow, will denudate the endothelial layer, resulting in platelet adhesion and initiation of a cascade of proteins that stimulate the smooth muscle cells to proliferate and migrate ${ }^{25-27}$. Due to the high thrombosis incidence the AVG is considered second choice for vascular access.

\section{Central venous catheter}

A central venous catheter (CVC) is preferably approached through the right jugular vein and positioned in the right atrium. Before the CVC penetrates the vein, it is tunneled subcutaneously for infection prevention. The left jugular vein is suited for CVC implantation as well, but is more difficult to insert, due to the curved vein route to the right atrium. The femoral vein is used only when above-mentioned puncture sites are not suitable for CVC implantation. The subclavian vein site is discouraged because the subclavian vein is sensitive for stenosis formation at the puncture site. It may cause central venous obstruction which may hamper future ipsilateral AVG or AVF creation ${ }^{28}$. CVC are ideal for acute vascular access, because these are relatively easy to implant using only local anesthetics, and can be used immediately.

However, long-term use of a CVC is strongly discouraged ${ }^{11,12}$ because of the significant higher mortality rate due to infection, compared to internal vascular accesses ${ }^{29}$. This is why a CVC is considered third choice for vascular access creation.

\section{Vascular access surveillance}

Vascular access surveillance is the frequent use of diagnostic tools that can identify a vascular access at risk for thrombosis. Timely detection and preemptive intervention is necessary to prevent the access from (irresolvable) dysfunction. The main cause of dysfunction of AVG and AVF is thrombosis ${ }^{30}$, which is primarily related to the vascular remodeling and adaptation to high-flow conditions as described before.

There are several methods to detect a vascular access at risk for thrombosis: 


\section{Physical examination}

A significant narrowing due to neointimal hyperplasia (stenosis) exhibits several physical symptoms. The stenosis may be visible (strictures) and detectable by palpation (thrill at stenosis location) and the stenosis might also be audible (high frequent sound). Arm elevation is a test to reveal possible venous outflow stenosis: An AVF should at least partially collapse with arm elevation otherwise is likely to have an outflow stenosis. This logic applies to the case in which a tourniquet does not appear necessary for AVF cannulation for the pressure upstream of the stenosis location elevates. Strong pulsations in AVG are likely to reflect outflow stenosis as well. Other symptoms of outflow obstruction are prominent collateral veins, edema and prolonged bleeding from needle sites ${ }^{31}$.

\section{Pressure measurement}

Dynamic venous pressures (DVP) are recorded during hemodialysis treatment. The venous pressure (measured at the air-trap, Figure 1.1) is the sum of the needle pressure and the intra-access pressure (IAP). A significant increase in DVP might reflect outflow stenosis. However many factors influence DVP: different extracorporeal blood pump speed $(\mathrm{Qb})$ settings, difference in hematocrit levels, clotting at the air-trap, use of different needle sizes, needle position, and height differences between the location of the pressure transducer and the vascular access. Only a small percentage $(+/-20 \%)$ of DVP reflects actual IAP ${ }^{32}$. A significant IAP increase is only minor reflected in DVP, and therefore DVP has low sensitivity towards hemodynamically significant stenosis.

On the contrary, static venous pressure (SVP) is measured with zero $\mathrm{Qb}$, a better measure for actual intra-access pressure. Besarab et al. ${ }^{33}$ studied the relation between IAP and mean arterial pressure (MAP): When the ratio between SVP and MAP exceeds the threshold of 0.5 , it is likely to predict venous outflow stenosis.

\section{Recirculation measurement}

Recirculation is the return of dialyzed blood to the dialyzer without equilibration with the systemic arterial circulation. There are several easy to execute measurement techniques available. Access recirculation in a properly cannulated access is a sign of low access blood flow ( $\mathrm{Qa}$ ). It appears when $\mathrm{Qa}$ is lower than $\mathrm{Qb}$. This is why recirculation measurements are practically useless in AVG, which require much higher flows to prevent thrombosis ${ }^{11}$. 


\section{Access flow measurement}

MAP divided by the vascular access circuits' resistance determines Qa. A hemodynamically significant stenosis alters access resistance and thus $Q$ a.

Knowledge of Qa enables the detection of a growing stenosis regardless of its location and the possible formation of collaterals, contrary to pressure surveillance. Regular $\mathrm{Qa}$ measurement can detect access deterioration long before a measurable access recirculation appears. Thus Qa appears to be the most logical parameter for stenosis detection. Several studies proved its' sensitivity in stenosis detection ${ }^{34,35,36}$.

Online Qa evaluation is defined as measurement of access flow using a technique that is inherently linked to the presence of the extracorporeal circulation during $H D$ treatment. A Qa $<600 \mathrm{ml} / \mathrm{min}$ (AVG), a Qa $<400 \mathrm{ml} / \mathrm{min}$ (AVF) or a Qa decline $>25 \%$ versus previous measurement (AVG) suggests the presence of a hemodynamic significant stenosis ${ }^{11}$. Several online measurements techniques for $\mathrm{Q} a$ assessment are available. Lopot et al. ${ }^{37}$ compared available online Qa techniques and identified the ultrasound dilution technique ${ }^{38}$ (Transonic Systems, Ithaca, NY) as most accurate.

It is important that $\mathrm{Q}$ a measurements are executed repetitive (monthly ${ }^{11,12}$ ) and during comparable hemodynamic circumstances.

The flowchart in Figure 1.3 displays a protocol example.

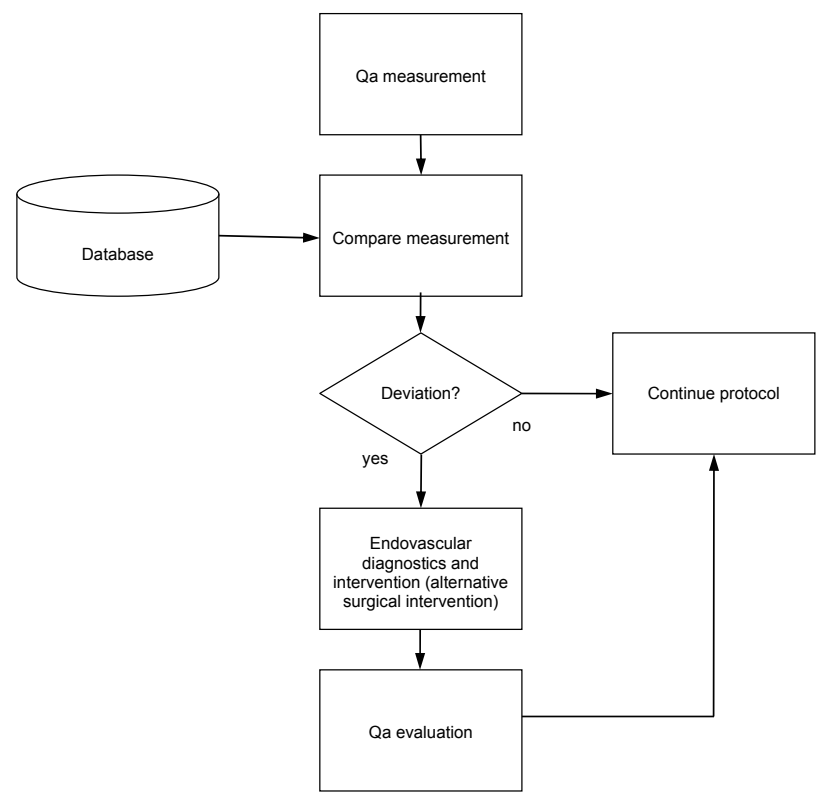

Figure 1.3 Flowchart vascular access flow surveillance. $\mathrm{Qa}=$ access flow in $\mathrm{ml} / \mathrm{min}$. 


\section{Imaging techniques}

In addition to flow measurements, both duplex ultrasonography (DUS) and contrastenhanced magnetic resonance imaging (CE-MRA) ${ }^{39}$ provide anatomic assessment and direct evidence for the presence, location, and severity of access stenosis. However, the cost of these methods, as well as the inability to make measurements during HD, limits their use. Of course, DUS and CE-MRA are an important means for further diagnostics, when any of above described surveillance tests that can be executed before or during HD, are positive. Contrary to DUS and CE-MRA, digital substraction angiography (DSA), is an imaging technique that has the benefit that intervention through percutaneous transluminal angioplasty (PTA) can be performed during the same session. This is why it is more or less the gold standard for stenosis assessment after positive surveillance criteria ${ }^{11,12}$.

\section{Introduction to the study}

\section{Access flow surveillance and access failure}

Vascular access problems are responsible for a considerable amount of morbidity in patients on HD. Access dysfunction accounts for approximately $25 \%$ of hospitalizations, with consequent major healthcare costs ${ }^{40}$. Dysfunction of the vascular access limits efficient HD treatment and may result in underdialysis and in consequence to increased morbidity and mortality ${ }^{41}$. Logically, strategies to prevent access failure are of the utmost importance. Though guidelines ${ }^{11,12}$ recommend access surveillance programs, preferably based on access flow monitoring, there is quite some discussion ${ }^{42-45}$ regarding outcome of such surveillance programs.

Chapter 2 describes a comparison between two different periods in time at the same dialysis unit, during which in the first period no structured surveillance was applied, and during which in the second period access flow surveillance was applied. The comparison focuses on cost effectiveness, access thrombosis and access failure.

Chapter 3 presents the results of a systematic literature search regarding the value of online vascular access flow measurement combined with preemptive intervention, on the incidence of access occlusion. Important differences in appliance of access flow monitoring and preemptive intervention are discussed. 


\section{Novelty in access flow assessment}

New techniques compared to the current reference technique to online measure access flow are of interest because these might increase measurement frequency through integration in the dialysis machine and operator simplification.

In Chapter 4, the thermodilution technique to measure access flow, which measurement device is embedded in the dialysis machine itself, will be compared to the reference technique based on saline dilution, which is a single setup measurement device. Differences and similarities between both techniques will be described. Agreement between the results of each technique is given together with the reproducibility results per technique.

In Chapter 5 a similar study will be described in which the reference technique is compared to a novel technique that measures access flow based on extracorporeal temperature gradients and does not require dilution.

Chapter 6 reflects on the surplus value of one of the oldest approaches to vascular access surveillance, access recirculation, when compared to access flow surveillance, in the light of the results of a new technique to measure access recirculation.

\section{Type of access and hemodynamic consequences}

Cardiac performance changes due to the presence of an AVF: total vascular resistance will decrease, resulting in an increased stroke volume and $\mathrm{CO}$ in order to maintain blood pressure. High flow fistulae, like upper arm fistulae, might increase cardiac volume load even more. Access-related hemodynamic parameters are relatively easy to assess during HD treatment.

In Chapter 7 the relation between vascular access flow and different types of vascular access with systemic hemodynamics will be studied. 


\section{Aims of this thesis}

1. To determine if a quality improvement program based on vascular access flow monitoring has effect on healthcare costs

2. To review the outcome of online vascular access flow surveillance when combined with preemptive intervention

3. To determine the agreement, reproducibility and the usefulness of an existing and a novel technique to online measure vascular access flow in comparison to the gold standard technique to online measure vascular access flow

4. To assess the relation between vascular access flow and different types of vascular access with systemic hemodynamics 


\section{References}

1. Grassmann A, Gioberge S, Moeller S, Brown G. ESRD patients in 2004: global overview of patient numbers, treatment modalities and associated trends. Nephrol Dial Transplant 2005;20:2587-2593.

2. Kolff WJ, Berk HTh. The artificial kidney: a dialyzer with a great area. Acta Med Scand 1944;117:121-134.

3. Alwall N, Norvitt L, Steins AM. The artificial Kidney. VII. Clinical experiences of dialytic treatment of uraemia. Acta Med Scand 1949;132:587.

4. Cimino JE, Brescia JB, Appel K, Hurwich BH. Chronic hemodialysis using venipuncture and a surgically created arteriovenous fistula. N Engl J Med 1966;275:1089.

5. Hakim R, Himmelfarb J: Hemodialysis access failure: a call to action. Kidney Int 1998; 54:1029-1040.

6. Stengel B, Billon S, Van Dijk PC, Jager KJ, Dekker FW, Simpson K, Briggs JD. Trends in the incidence of renal replacement therapy for end-stage renal disease in Europe, 1990-1999. Nephrol Dial Transplant 2003;18:1824-1833.

7. Wakai K, Nakai S, Kikuchi K, Iseki K, Miwa N, Masakane I, Wada A, Shinzato T, Nagura Y, Akiba T. Trends in incidence of end-stage renal disease in Japan, 1983-2000: age-adjusted and age-specific rates by gender and cause. Nephrol Dial Transplant 2004;19:2044-2052.

8. Termorshuizen F, Korevaar JC, Dekker FW, Jager KJ, van Manen JG, Boeschoten EW, Krediet RT. Time trends in initiation and dose of dialysis in end-stage renal disease patients in The Netherlands. Nephrol Dial Transplant 2003;18:552-558.

9. Stewart JH, McCredoe MR, Williams SM, McDonald SP. Interpreting incidence trends for treated end-stage renal disease: implications for evaluating disease control in Australia. Nephrology 2004;9:238-246.

10. Tordoir JH, Rooyens P, Dammers R, van der Sande FM, de Haan M, Yo TI. Prospective evaluation of failure modes in autogenous radiocephalic wrist access for hemodialysis. Nephrol Dial Transplant 2003;18:378-383.

11. NKF-K/DOQI. Clinical Practice Guidelines for Vascular Access, update 2006 American Journal of Kidney Diseases 2006;48(S1):S176-S247.

12. Tordoir J, Canaud B, Haage P, Konner K, Basci A, Fouque D, Kooman J, Martin-Malo A, Pedrini L, Pizzarelli F, Tattersall J, Vennegoor M, Wanner C, Ter Wee P, Vanholder R. EBPG on Vascular Access. Nephrol Dial Transplant 2007;22(Suppl 2):ii88-ii117.

13. Fitzgerald JT, Schanzer A, Chin AI, McVicar JP, Perez RV, Troppmann C. Outcomes of upper arm arteriovenous fistulas for maintenance hemodialysis access. Arch Surg. 2004; 139:201-208.

14. Keuter XH, van der Sande FM, Kessels AG, de Haan MW, Hoeks AP, Tordoir JH. Excellent performance of one-stage brachial-basilic arteriovenous fistula. NDT 2005;20:2168-2171.

15. Hoek van F, Scheltinga MR, Kouwenberg I, Moret KE, Beerenhout CH, Tordoir JH. Steal in Hemodialysis Patients Depends on Type of Vascular Access. Eur J Vasc Endovasc Surg. 2006;32:710-717.

16. Wijnen E, Keuter XH, Planken NR, van der Sande FM, Tordoir JH, Leunissen KM, Kooman JP. The relation between vascular access flow and different types of vascular access with systemic hemodynamics in hemodialysis patients. Artif Organs 2005;29:960-964.

17. Pandeya S, Lindsay RM. The relationship between cardiac output and access flow during hemodialysis. ASAIO J 1999;45:135-138.

18. MacRae JM, Pandeya S, Humen DP, Krivitski N, Lindsay RM. Arteriovenous fistulaassociated high-output cardiac failure: a review of mechanisms. Am J Kidney Dis 2004;43: e17-22.

19. Kajiwara IS, Kondo J, Matsumoto A. Banding a hemodialysis arteriovenous fistula to decrease blood flow and resolve high output cardiac failure: report of a case. Surgery Today 1994;24:734-736.

20. Bailey WB, Talley JD. High output cardiac failure related to hemodialysis arteriovenous fistula. J Ark Med Soc 2000;96;340-341. 
21. Young PR Jr, Rohr MS, Marterre WF. High-output cardiac failure secondary to a brachiocephalic arteriovenous hemodialysis fistula: two cases. Jr. Am Surg. 1998;64: 239-241.

22. Engelberts I, Tordoir JH, Boon ES and Schreij G. High-output cardiac failure due to excessive shunting in a hemodialysis access fistula: an easily overlooked diagnosis. Am J Nephrology 1995; 15:323-326.

23. Henriksson $A E$, Bergqvist $D$. Steal syndrome of the hemodialysis vascular access: diagnosis and treatment. J Vasc Access 2004;5:62-68.

24. Ruddle AC, Lear PA, Mitchell DC. The morbidity of secondary vascular access. A lifetime of intervention. Eur J Vasc Endovasc Surg 1999;18:30-34.

25. Hofstra L, Bergmans DC, Leunissen KM, Hoeks AP, Kitslaar PJ, Tordoir JH. Prosthetic arteriovenous fistulas and venous anastomotic stenosis: influence of a high flow velocity on the development of intimal hyperplasia. Blood Purificat 1996; 14:345-349.

26. Roy-Chaudhury P, Kelly BS, Narayana A et al. Hemodialysis vascular access dysfunction from basic biology to clinical intervention. Adv Renal Replace Ther 2002; 9: 74-84.

27. Lemson MS, Tordoir JHM, Daemen MJAP, Kitslaar PJEHM. Intimal hyperplasia in vascular grafts. Eur J Vasc Endovasc Surg 2000; 19: 336-351.

28. Dammers R, de Haan MW, Planken NR, van der Sande FM, Tordoir JH. Central vein obstruction in hemodialysis patients: results of radiological and surgical intervention. Eur $\mathrm{J}$ Vasc Endovasc Surg. 2003;26:317-321.

29. Schwab SJ and Beathard G. The hemodialysis catheter conundrum: hate living with them, but can't live without them. Kidney Int 1999;56:1-17.

30. Feldman $\mathrm{HI}$, Kobrin S, Wasserstein A. Hemodialysis vascular access morbidity. J Am Soc Nephrol 1996;7:523-535.

31. Beathard GA. Physical examination of AV grafts. Semin Dial 1996;5:74.

32. Lopot F, Nejedlý B, Válek M. Vascular access monitoring: methods and procedures-something to standardize? Blood Purif. 2005;23:36-44.

33. Besarab A, Sullivan KL, Ross RP, Moritz MJ. Utility of intra-access pressure monitoring in detecting and correcting venous outlet stenoses prior to thrombosis. Kidney Int. 1995;47: 1364-1373

34. Bosman PJ, Boereboom FT, Eikelboom BC, Koomans HA, Blankestijn PJ. Graft flow as a predictor of thrombosis in hemodialysis grafts. Kidney Int 1998;54:1726-1730.

35. Rehman SU, Pupim LB, Shyr Y, Haikim R, Ikizler TA. Intradialytic serial vascular access flow measurements. Am J Kidney Dis 1999;34:471-477.

36. Garland JS, Moist LM, Lindsay RM. Are hemodialysis access flow measurements by ultrasound dilution the standard of care for access surveillance? Adv Ren Replace Ther 2002;9:91-98.

37. Lopot F, Nejedlý B, Sulková S, Bláha J. Comparison of different techniques of hemodialysis vascular access flow evaluation. Int J Artif Organs. 2003;26:1056-1063.

38. Krivitski NM. Novel method to measure access flow during hemodialysis by ultrasound velocity dilution technique. ASAIO J. 1995;41:M741-745.

39. Planken RN, Tordoir JH, Dammers R, de Haan MW, Oei TK, van der Sande FM, van Engelshoven JM, Leiner T. Stenosis detection in forearm hemodialysis arteriovenous fistulae by multiphase contrast-enhanced magnetic resonance angiography: preliminary experience. J Magn Reson Imaging. 2003;17:54-64.

40. Rayner HC, Pisoni RL, Bommer J, Canaud B, Hecking E, Locatelli F, Piera L, BraggGresham JL, Feldman HI, Goodkin DA, Gillespie B, Wolfe RA, Held PJ, Port FK. Mortality and hospitalization in hemodialysis patients in five European countries: results from the Dialysis Outcomes and Practice Patterns Study (DOPPS). Nephrol Dial Transplant 2004; 19:108-120.

41. Hakim RM, Breyer J, Ismail N, Schulman G. Effects of dose of dialysis on morbidity and mortality. Am J Kidney Dis 1994;23:661-669.

42. Besarab A. Access monitoring is worthwhile and valuable. Blood Purif 2006;24:77-89.

43. Paulson WD. Access monitoring does not really improve outcomes. Blood Purif 2005;23: 50-56. 
44. Sands JJ. Vascular access monitoring improves outcomes. Blood Purif 2005;23:45-49.

45. Work J. Does vascular access monitoring work? Adv Ren Replace Ther 2002;9:85-90. 



\section{Chapter 2}

\section{Impact of a quality improvement program based on vascular access flow monitoring on costs, access occlusion and access failure}

E Wijnen, N Planken, X Keuter, JP Kooman, JHM Tordoir, MW de Haan, KML Leunissen, FM van der Sande 


\section{Abstract}

\section{Introduction}

Vascular access thrombosis is a substantial source of morbidity in chronic haemodialysis patients. Periodical access flow measurements can predict the presence of vascular access stenosis and provide an opportunity for early intervention to prevent subsequent vascular access thrombosis. By this system of quality improvement, vascular access related costs might be reduced. The aim of this study was to analyze the cost impact of a quality improvement program based on periodic access flow measurements.

\section{Methods}

The number and costs of vascular access interventions (summary of angiography, percutaneous transluminal angioplasty, catheter placement, hospitalisation days and costs for surgery) in the period 2001 till 2003 (Quality improvement period; QIP, 218.6 patient years observed) were retrospectively compared with a reference period (RP, 1996 till 1998, 214.4 patient years observed) during which no access flow was measured. All access flow measurements were done on a regular base and interventions were performed according to K/DOQI guidelines.

\section{Results}

Surgical thrombectomy procedures were significantly less during the QIP $(0.25+/-0.57$ events/patient yr) compared to RP $(0.63+/-1.06$ events/patient $y r ; p=0.000)$, whereas access loss was not significantly different. During the QIP 205 radiological interventions were performed $(0.88+/-1.16$ events/patient yr), and in the RP $48(0.33+/-0.65$ events/patient $y r ; p=0.000)$. Access related costs tended to be lower during the QIP compared to the RP. The cost reduction appeared to be limited to patients with arteriovenous graft (AVG), in which access related costs were significantly lower during the QIP $(€ 2,360.95+/-2,838.17$ per patient $\mathrm{yr})$ compared to the RP $(€ 4,003.96+/-3,810.92$ per patient $y r ; p=0.012)$, but not in patients with arteriovenous fistula (AVF).

\section{Conclusion}

A quality improvement program based on periodically access flow measurement reduced the number of acute vascular access failures due to thrombotic events and also significantly reduced health care costs in patients with AVG, but not in patients with AVF. The quality improvement program had no effect on access survival. 


\section{Introduction}

Nowadays, more than 300.000 patients in the USA, and similar patient numbers in Europe, are being kept alive by chronic intermittent dialysis treatment. It has been estimated that this number will increase dramatically the forthcoming years. The increase in number of elderly dialysis patients with additional cardiovascular comorbidities and diabetes mellitus makes the creation and maintenance of functioning vascular access more difficult and cumbersome. Vascular access problems place a large burden on care facilities, manpower and costs. In Europe alone, approximately 60.000 new accesses and more than 24.000 access replacements per year are performed. In addition, it has been estimated that an autogenous arteriovenous fistula (AVF) needs 0.2-0.4 revision/year and an arteriovenous graft (AVG) about 0.8-1.2 revisions/year for maintenance ${ }^{1-4}$, counting for another 70.000 interventions/year. The vascular access related costs are substantial due to vascular access complications. The Kidney Disease Outcome Quality Initiative (K/DOQI) clinical practice guidelines for Vascular Access (update 2000) recommend monitoring of vascular access by periodical flow measurements ${ }^{5}$. Little is known about the economic effects of maintenance of vascular access. Recently, in a prospective study the cost analysis of vascular access among incident haemodialysis patients during the first year of dialysis was determined ${ }^{6}$. However this study did not take into account the effect of a vascular access surveillance program on saving costs. Monthly monitoring of access flow may be of importance in preventing access clotting.

The hypothesis of the present study was that implementation of a quality improvement program with periodical access flow measurement, may reduce vascular access related health care costs.

The aim of the present study was therefore, first to analyze the cost impact of a quality improvement program and secondly to study the effect of such a program on the incidence of thrombotic vascular access events and access loss.

\section{Patients and methods}

\section{Study protocol}

Retrospectively, two patient cohorts were formed; the Reference Period (RP) (19961998) and the Quality Improvement Period (QIP) (2001-2003). The gap (1999-2000) between the RP and the QIP was the period in which the Transonic HD01 ${ }^{\circledR}$ (Transonic Systems Inc., Ithaca, NY) was acquired and introduced. This time lap was chosen 
because the K/DOQI Update 2000 on vascular access recommends an organized monitoring approach of vascular access flow ${ }^{5}$.

The incidence of preemptive intervention and vascular access failure due to thrombotic occlusive event within both periods was registered to determine the effect of access flow based radiological intervention on vascular access maintenance costs.

During both periods it was standard procedure to perform a surgical thrombectomy of an occluded vascular access, as well in AVG as in AVF. For surgical thrombectomy, patients were hospitalized for three days. Not all occluded vascular access sites were suitable for revision. Patients with access loss were given a central vein catheter to overcome the period in which a new vascular access site was created and suitable for cannulation. During both periods, RP and QIP, the same highly experienced vascular access surgeon was responsible for surgical thrombectomy and new access site creation.

The vascular access surveillance program during the RP was based on nonstandardized vascular access surveillance tools, consisting of frequent palpation before access cannulation, incidental auscultation before haemodialysis treatment and registering of arterial and venous pressure findings during haemodialysis treatment. Based on abnormal findings (increased arterial and/or venous pressure, a change in thrill or palpation, and/or high frequent sounds on auscultation) the preferred action was angiography and, in case of a stenotic lesion, followed by percutaneous transluminal angioplasty (PTA). During the QIP, the vascular access surveillance was based on monthly (arteriovenous graft (AVG)), and three monthly (arteriovenous fistula (AVF)) vascular access flow measurement, using the Transonic HD0 ${ }^{\circledR}$ access flow monitor. In case of low vascular access flow or a substantial flow decline according to K/DOQI Update 2000 on clinical practice guidelines for vascular access ${ }^{5}$, the preferred treatment was also angiography combined with PTA.

Measurements were performed by a group of dialysis nurses during the first hour of dialysis. Although this takes a maximum time period of 15 minutes per measurement, no extra staff was needed to perform these measurements.

\section{Patients}

All local incident haemodialysis patients with a vascular access, AVF and AVG, were included. During the RP 214.4 patient years were observed (total number of patients: 119), whereas in the QIP 218.6 patient years were observed (total number of patients: 117). Patient characteristics are described in Table 2.1. 
Table 2.1 Patient characteristics

\begin{tabular}{lccc}
\hline & RP; $1996-1998$ & QIP; 2001-2003 & P Value \\
\hline Included patients & 119 & 117 & NS \\
Patient years observed (total,/mean,/SD) & $214.4(1.85+/-0.95)$ & $218.6(1.89+/-0.92)$ & NS \\
Average age & $63.4+/-13.8$ & $65.4+/-13.1$ & NS \\
Male / Female & $59 \% / 41 \%$ & $56 \% / 44 \%$ & NS \\
DM & $19 \%$ & $25 \%$ & NS \\
Primary / Secondary renal failure & $40 \% / 60 \%$ & $31 \% / 69 \%$ & NS \\
Average time on dialysis (years) & $2.61+/-1.84$ & $2.96+/-2.07$ & $\mathrm{NS}$ \\
AVF / AVG & $53 \% / 47 \%$ & $51 \% / 49 \%$ & $\mathrm{NS}$ \\
Average age AVG in years & $1.80+/-1.20$ & $2.14+/-1.48$ & $\mathrm{NS}$ \\
Average age AVF in years & $3.09+/-2.31$ & $2.59+/-1.88$ & $\mathrm{NS}$ \\
Lower arm AVF / upper arm AVF & $94 \% / 6 \%$ & $78 \% / 22 \%$ & $\mathrm{NS}$ \\
\hline
\end{tabular}

$\mathrm{RP}$ is reference period. QIP is quality improvement period. DM is diabetes mellitus. AVF is arteriovenous fistula. AVG is arteriovenous graft.

\section{Cost calculation}

Cost data were delivered by the hospitals financial administration and were based upon costs for the different interventions and procedures in december 2002. These cost data were uniformly used for both periods in order to make a comparison possible. Cost calculation is based on local hospital costs of imaging, interventions and, when surgical procedure was needed, hospitalization. Amounts are reported in EURO (€) (Table 2.2). The following procedures were taken into account: angiography, angiography combined with PTA, central vein catheter placement, surgical thrombectomy, new vascular access site creation, devaluation costs Transonic $\mathrm{HDO}^{\circledR}{ }^{\circledR}$ and access flow measurement related labour costs. Procedure costs are the actual effective costs consisting of personnel, equipment, material and overhead costs. Hospitalization costs are also effective costs based on an average hospitalization day on the surgical unit. For the cost calculation regarding hospitalisation, the primary reason for admission had to be access failure. If an access failed during a hospitalisation period during which patients were admitted for other complications (e.g. pneumonia), only the costs directly related to access failure were included in the calculations.

Table 2.2 Relevant costs

\begin{tabular}{ll}
\hline & Costs $(€)$ \\
\hline Angiography & 343.13 \\
Angiography combined with PTA & 564.67 \\
Central catheter & 495.25 \\
Surgical revision & $1,932.86$ \\
Hospitalisation per day & 257.46 \\
Access flow measurement (labour costs) & 4.75 \\
Devaluation costs Transonic HD01 (2001-2003) & 3000.00 \\
\hline
\end{tabular}

PTA is percutaneous transluminal angioplasty. Access flow measurement labour costs are based on 15 minutes per measurement. 


\section{Access flow measurements by dilution technique}

The access flow measurement technique involves reversing the access lines during dialysis and using the ultrasound dilution methodology as introduced by $\mathrm{Krivitski}^{7}$ to measure the resulting fraction of recirculated blood $(R)$ entering the dialyzer. If the extra corporeal pump speed $\left(Q_{b}\right)$ is known, then access flow $\left(Q_{a}\right)$ can be calculated from the following formula: $Q a=Q b \times((1-R) / R)$

\section{Dialysis strategy}

In the QIP as well as in the RP, patients were treated with bicarbonate haemodialysis with low flux polysulfone membranes (F8HPS; Fresenius ${ }^{\circledR}$; Bad Homburg or Polyflux 8L; Gambro $^{\circledR}$; Lund; Sweden). Sodium concentration of the dialysate was 138 or 140 $\mathrm{mmol} / \mathrm{l}$, calcium concentration was $1.5 \mathrm{mmol} / \mathrm{l}$ and temperature of the dialysate was $35.5,36$ or $36.5^{\circ} \mathrm{C}$. Ultrapure dialysate was used.

\section{Statistical analysis}

Differences between QIP and RP were analyzed using Poisson or Chi-square tests and Mann Whitney U-tests, where appropriate (SPSS-pc version 12.01). All values are expressed as mean \pm standard deviation (SD) and range is added for costs. P-value $<0.05$ was considered significant.

\section{Results}

\section{Interventions}

Qa screening was performed in all patients during the QIP, with a total of 1652 measurements (7.56 events/patient year).

During the RP a total of $77(0.53+/-1.25$ events/patient $\mathrm{yr})$ angiographic procedures without additional PTA were performed compared to $57(0.28+/-0.55$ events/patient yr, $\mathrm{p}=0.047)$ in the QIP. Angiography with additional PTA was performed 48 times $(0.33+/-0.65$ events/patient year) in the RP and 205 times $(0.88+/-1.16$ events/patient yr; $\mathrm{p}=0.000$ ) in the QIP.

The number of vascular access thrombectomies (both AVF and AVG) was higher during RP; $108(0.63+/-1.06$ events/patient yr) compared to $60(0.25+/-0.57$ events/patient year; $p=0.000$ ) during QIP (Figure 2.1).

Subgroup analysis yielded $0.21+/-0.40$ AVF thrombotic occlusive event/patient $y r$ in the RP compared to $0.09+/-0.29$ in the QIP, $p=0.022$, and $1.14+/-1.36$ AVG thrombotic occlusive event/patient $y r$ in the RP compared to $0.45+/-0.74$ in the QIP, $p=0.000$. 


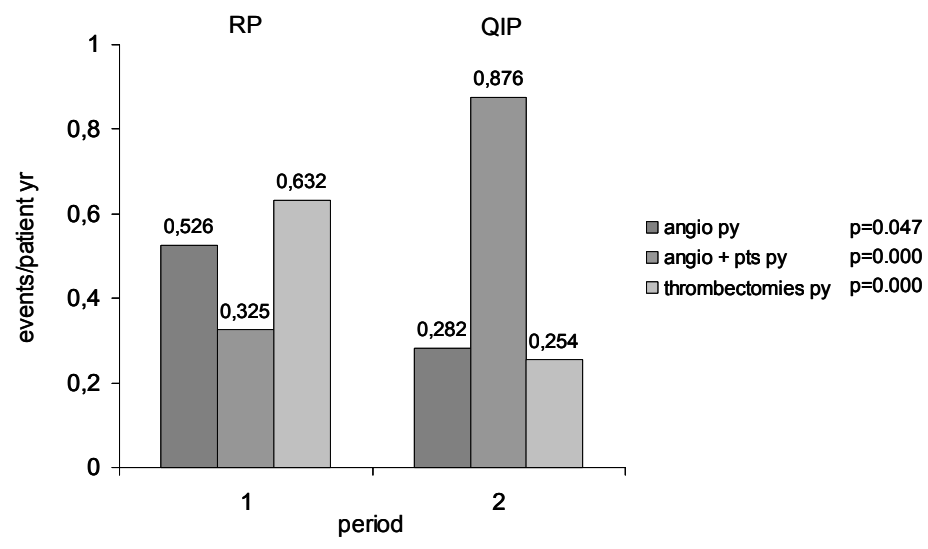

Figure 2.1 Vascular access related interventions during the RP and the QIP

$\mathrm{RP}$ is reference period. QIP is quality improvement period. PTA is percutaneous transluminal angioplasty.

\section{Costs}

Table 2.3 summarizes all costs for both the RP and the QIP population. Table 2.4 and 2.5 summarize all costs per period for AVG and AVF, respectively. Vascular access related costs tended to be lower during the QIP compared to RP for the overall groups. The total costs per patient year decreased from $€ 2,289.16+/-3,153.68$ in the RP to $€ 1,538.40+/-2,279.90$ in the QIP, which is a relative downtrend of $32.5 \%, p=n s$. However, when distinguishing between patients with AVF and AVG, in patients with AVG a highly significant cost reduction was observed (costs per patient yr RP $€ 4,003.96+/-3,810.92$, costs per patient yr QIP $€ 2,360.95+/-2,838.17 ; p=0.01)$, but not in patients with AVF.

Table 2.3 Summary of intervention costs by period

\begin{tabular}{lccccccc}
\hline & $\begin{array}{c}\text { Costs }(€) \mathrm{RP} \\
\text { per patient/yr }\end{array}$ & SD & range & $\begin{array}{c}\text { Costs }(€) \text { QIP } \\
\text { per patient/yr }\end{array}$ & SD & range & $P$ Value \\
\hline Angiography & 180.56 & $+/-428.84$ & $0-1,170$ & 96.90 & $+/-189.19$ & $0-1,882$ & 0.047 \\
Angiography and PTA & 177.69 & $+/-355.90$ & $0-1,882$ & 479.08 & $+/-635.54$ & $0-4,106$ & 0.000 \\
Central catheter & 34.12 & $+/-101.83$ & $0-665$ & 32.41 & $+/-94.61$ & $0-512$ & NS \\
New access site creation & 133.17 & $+/-397.41$ & $0-2,594$ & 126.49 & $+/-369.22$ & $0-1,999$ & NS \\
Surgical thrombectomy & $1,222.07$ & $+/-2,052.03$ & $0-14,596$ & 491.59 & $+/-1,105.12$ & $0-6,703$ & 0.000 \\
Hospitalisation & 541.56 & $+/-868.51$ & $0-5,833$ & 246.99 & $+/-521.16$ & $0-3,348$ & 0.001 \\
Access flow measurement & 0 & & & 46.95 & $+/-35.85$ & $3-200$ & 0.000 \\
Devaluation costs HD01 & 0 & & & 17.99 & $+/-12.01$ & $1-76$ & 0.000 \\
Total costs: & $2,289.16$ & $+/-3,153.68$ & $0-20,429$ & $1,538.40$ & $+/-2,279.90$ & $4-13,875$ & NS \\
\hline
\end{tabular}

$\mathrm{RP}$ is reference period. QIP is quality improvement period. PTA is percutaneous transluminal angioplasty. 
Table 2.4 Summary of intervention costs for AVG by period

\begin{tabular}{lccccccc}
\hline & $\begin{array}{c}\text { Costs }(€) \mathrm{RP} \\
\text { patient/yr }\end{array}$ & SD & range & $\begin{array}{c}\text { Costs }(€) \text { QIP } \\
\text { patient/yr }\end{array}$ & SD & range & $P$ Value \\
\hline Angiography & 212.83 & $+/-250.98$ & $0-1,170$ & 101.77 & $+/-178.16$ & $0-1,882$ & 0.009 \\
Angiography and PTA & 238.00 & $+/-404.50$ & $0-1,865$ & 650.98 & $+/-681.41$ & $0-4,106$ & 0.001 \\
Central catheter & 71.77 & $+/-140.73$ & $0-665$ & 54.33 & $+/-121.95$ & $0-512$ & NS \\
New access site creation & 280.10 & $+/-549.24$ & $0-2,594$ & 212.03 & $+/-475.95$ & $0-1,999$ & NS \\
Surgical thrombectomy & $2,207.29$ & $+/-2,618.40$ & $0-14,596$ & 866.34 & $+/-1,428.99$ & $0-6,703$ & 0.000 \\
Hospitalisation & 993.97 & $+/-1,084.10$ & $0-5,833$ & 430.92 & $+/-673.65$ & $0-3,348$ & 0.001 \\
Access flow measurement & 0 & & & 32.25 & $+/-20.30$ & $10-200$ & 0.000 \\
Devaluation costs HD01 & 0 & & & 12.33 & $+/-8.07$ & $4-76$ & 0.000 \\
Total costs: & $4,003.96$ & $+/-3,810.92$ & $0-20,429$ & $2,360.95$ & $+/-2,838.17$ & $14-13,875$ & 0.01 \\
\hline
\end{tabular}

$\mathrm{RP}$ is reference period. QIP is quality improvement period. PTA is percutaneous transluminal angioplasty. AVG is arteriovenous graft. The RP AVG group included 54 patients (98.4 patient years observed) and the QIP AVG group included 54 patients (105.8 patient years observed).

Table 2.5 Summary of intervention costs for AVF by period

\begin{tabular}{lccccccc}
\hline & $\begin{array}{c}\text { Costs }(€) \mathrm{RP} \\
\text { patient/yr }\end{array}$ & SD & range & $\begin{array}{c}\text { Costs }(€) \text { QIP } \\
\text { patient/yr }\end{array}$ & SD & range & $P$ Value \\
\hline Angiography & 153.75 & $+/-534.13$ & $0-607$ & 92.72 & $+/-199.49$ & $0-931$ & NS \\
Angiography and PTA & 127.55 & $+/-304.01$ & $0-1,001$ & 331.74 & $+/-557.66$ & $0-2,494$ & 0.005 \\
Central catheter & 2.85 & $+/-22.95$ & $0-185$ & 13.62 & $+/-57.06$ & $0-363$ & NS \\
New access site creation & 11.11 & $+/-89.57$ & $0-722$ & 53.17 & $+/-222.67$ & $0-1,417$ & NS \\
Surgical thrombectomy & 403.59 & $+/-765.99$ & $0-3,3359$ & 170.38 & $+/-558.77$ & $0-3,224$ & 0.022 \\
Hospitalisation & 165.72 & $+/-318.32$ & $0-1,342$ & 89.33 & $+/-255.98$ & $0-1,288$ & NS \\
Access flow measurement & 0 & & & 14.89 & $+/-13.78$ & $3-69$ & NS \\
Devaluation costs HD01 & 0 & & & 5.69 & $+/-4.09$ & $1-26$ & NS \\
Total costs: & 864.56 & $+/-1,329.72$ & $0-5,895$ & 771.54 & $+/-1,290.89$ & $4-5,628$ & NS \\
\hline
\end{tabular}

RP is reference period. QIP is quality improvement period. PTA is percutaneous transluminal angioplasty. AVF is arteriovenous fistula. The RP AVF group included 65 patients (116 patient years observed) and the QIP AVF group included 63 patients (112.8 patient years observed).

\section{Access loss}

Seventeen access losses were reported during the RP $(0.07+/-0.21$ events/patient yr), compared to 17 in the QIP $(0.07+/-0.19$ per events/patient $y r, p=n s)$. Patients with access loss received a central catheter until a new vascular access site was created, $0.08+/-0.21$ (RP) and 0.08+/-0.19 (QIP) events/patient year respectively, $p=n s$. Average access survival time until access loss was $888+/-748$ days in the RP $(\mathrm{N}=17)$ compared to $807+/-499$ days in the QIP $(\mathrm{N}=17), \mathrm{p}=\mathrm{ns}$. 


\section{Accuracy of the surveillance tools used in the RP and QIP for AVF and AVG}

In the QIP, PTA was executed in $71.9 \%$ of all AVF angiographic procedures, compared to $81.9 \%$ of all AVG angiographic procedures. In the RP, PTA was executed in $39.5 \%$ of all AVF angiographic procedures, compared to $37.8 \%$ of all AVG angiographic procedures.

During QIP, 0.85 angiographic procedures per patient/year were performed in AVF compared to 1.57 in AVG. During RP, 0.37 angiographic procedures per patient/year were performed in AVF compared to 0.83 in AVG.

\section{Discussion}

Implementation of a quality improvement program based on regular access flow measurement (QIP) resulted in a decline in thrombotic occlusive events, and surgical interventions and an increase in radiological interventions compared to conventional vascular access surveillance tools (RP). The reduction in vascular access related costs appeared to be primarily limited to patients with AVG. The quality improvement program had no effect on access survival.

\section{Effects of the QIP on access related morbidity}

Implementation of the decline limits in $\mathrm{Qa}$ for immediate radiological intervention (K/DOQI Update 2000 on vascular access) resulted in a reduction in thrombotic occlusive event rate during the QIP compared to the RP, where access surveillance was based on more conventional surveillance tools. The lower thrombotic occlusive event rate after implementation of an access flow based vascular surveillance program was observed both in patients with AVG and in patients with AVF, in agreement with earlier literature ${ }^{1-4}$. In our study, the reduction in occlusive event rate appeared to be highest in patients with AVG. As is well known, AVF's have a longer life span and need fewer interventions compared to AVG's as mentioned previously. This is reflected in the number of angiographic procedures, which was lower in patients with AVF compared to patients with AVG.

In agreement with earlier studies ${ }^{8-10}$, a quality improvement program based on access flow monitoring did not result in prolonged access survival. 


\section{Effects of the QIP on costs}

Cost effectiveness of an access flow based surveillance program has only been examined once to our knowledge. McCarley et al. ${ }^{11}$ analysed three phases of access thrombosis monitoring and treatment. Phase 1 consisted of haemodialysis treatment without access monitoring, phase 2 was a period of dynamic venous pressure monitoring and phase 3 a period of vascular access blood flow monitoring according to K/DOQI Update 2000 on clinical practice guidelines for vascular access ${ }^{5}$. The authors calculated an overall cost cutting benefit during phase 3 of $49 \%$ compared to phase 1 and $54 \%$ compared to phase 2 . The phase 3 period time however, was only 10 months. In the overall group, access-related costs tended to decline during the QIP. However, when distinguishing between AVF and AVG, the cost-reduction appeared to be limited in AVG, in which a highly significant reduction in costs was observed, which did not hold true in AVF. Two explanations might be provided for this difference. Firstly, in $81.9 \%$ of angiographic procedures in AVG, concomitant PTA was performed, compared to $71.9 \%$ in AVF. Thus, more unnecessary procedures may have been performed in the AVF group. Moreover, the reduction in access thrombosis during the QIP appeared to be higher for AVG (60.5\%) compared to AVF (57.1\%).

Several issues concerning our cost analysis deserve consideration.

Theoretically, in case of equal occlusive events, the use of percutanous thrombectomy would probably be less expensive because it can be performed in an outpatient setting. Green et al. ${ }^{12}$ however, performed a meta analysis comparing surgical thrombectomy with percutanous thrombectomy in AVG, which included 7 studies. They concluded that the overall results of this meta analysis showed a clear superiority of surgery over percutanous thrombectomy.

In case of outpatient surgery the cost analysis presumably would have been different because hospitalisation costs would be irrelevant. However, we feel that, at least in our hospital, outpatient surgery in case of thrombotic occlusive events are generally not feasible, due to logistic reasons but also due to the need for patient monitoring until the time of surgery and the moment of actual dialysis treatment.

The retrospective character of the study design causes some of the study's drawbacks. Although both patient cohorts (RP and QIP) seem to be comparable, the focus on failure was likely more intense during the QIP, due to the increased attention for quality improvement. Reasonably, this very focus resulted in better practice based educated personnel. Moreover, in agreement with recent trend, in the QIP there are more upper arm fistulas compared to the RP, although the ratio between AVF and AVG was not different. 


\section{Conclusion}

A quality improvement program based on periodically access flow measurement, with additional angiography and intervention, led to a reduction in the number of acute vascular access thrombotic occlusive events. Moreover, the QIP resulted in reduced health care costs in patients with AVG, but not in patients with AVF. However, the quality program had no effect on access survival. 


\section{References}

1. Schwab S, Oliver M, Suhocki P, McCann R: Hemodialysis arteriovenous access: Detection of stenosis and response to treatment by vascular access blood flow. Kidney Int 2001;59: 358-362.

2. Valj K: Prophylactic angioplasty: Is it worthwhile?; in Gray RJ, Sands JJ (eds): Dialysis Access: A Multidisciplinary Approach. Philadelphia, Lippincott Williams \& Wilkins, 2002; 153-156.

3. Sands J, Jabyac P, Miranda C, Kapsick B: Intervention based on monthly monitoring decreases hemodialysis access thrombosis. ASAIO J 1999;45:147-150.

4. Smits JH, Van Der Linden J, Hagen C, et al: Graft surveillance: Venous pressure, access flow or the combination? Kidney Int 2001;59:1551-1558.

5. NKF-K/DOQI: Clinical practice guidelines for vascular access: Update 2000. Am J Kidney Dis 2001;37:S137-S181.

6. Manns B, Tonelli M, Yilmaz S, Lee H, Laupland K, Klarenbach S, Radkevich V, Murphy B. Establishment and maintenance of vascular access in incident hemodialysis patients: a prospective cost analysis. J Am Soc Nephrol 2005;16:201-209.

7. Krivitski NM: Theory and validation of access flow measurement by dilution technique during haemodialysis. Kidney Int 1995;48:244-250.

8. Paulson WD. Access monitoring does not really improve outcomes. Blood Purif $2005 ; 23$ : 50-56.

9. Moist LM, Churchill DN, House AA, Millward SF, Elliott JE, Kribs SW, DeYoung WJ, Blythe L, Stitt LW, Lindsay RM. Regular monitoring of access flow compared with monitoring of venous pressure fails to improve graft survival. J Am Soc Nephrol 2003;14:2645-2653.

10. Dember LM, Holmberg EF, Kaufman JS. Randomized controlled trial of prophylactic repair of hemodialysis arteriovenous graft stenosis. Kidney Int 2004;66:390-398.

11. McCarley P, Wingard RL, Shyr Y, Pettus W, Hakim R, Ikizler TA: Vascular access blood flow monitoring reduces access morbidity and costs. Kidney Int 2001;60:1164-1172.

12. Green LD, Lee DS, Kucey DS. A metaanalysis comparing surgical thrombectomy, mechanical thrombectomy, and pharmacomechanical thrombolysis for thrombosed dialysis grafts. J Vasc Surg 2002;36:939-945. 


\section{Chapter 3}

\section{Effect of online hemodialysis vascular access flow evaluation and pre-emptive intervention on the frequency of access thrombosis}

E Wijnen, FM van der Sande, JHM Tordoir, JP Kooman, KML Leunissen

NDT Plus. 2008;5:279-284 


\section{Abstract}

\section{Introduction}

Guidelines advocate surveillance of vascular access to reduce incidences of thrombosis. However, the value of online vascular access flow monitoring is still under debate.

\section{Methods}

Through a systematic literature search, the effect of online access flow surveillance combined with pre-emptive intervention on the effect of thrombosis frequency is reviewed.

\section{Results}

Due to methodological differences, adequate comparison of the individual study results is not possible. Moreover, the methodological quality of most of the included studies is not suitable for an adequate statistical analysis of the results.

\section{Conclusion}

Until now, there is no conclusive evidence that online access flow evaluation has a significant effect on the rate of thrombosis. Future large-scale studies with adequate study design, adequate surveillance, and intervention protocols and, possibly, better pre-emptive intervention alternative(s) are necessary. 


\section{Introduction}

It has been estimated that vascular access morbidity is responsible for $25 \%$ of all hospital admissions in chronic hemodialysis patients ${ }^{1}$. The main cause of dysfunction of arterio venous grafts (AVG) and arterio venous fistula (AVF) is stenosis (and subsequent thrombosis), which is primarily related to the vascular remodeling and adaptation to high-flow conditions. The rationale for implementing a vascular access surveillance programme is that timely detection of stenosis combined with either radiological and/or surgical preemptive intervention could reduce thrombotic occlusive events and may prolong access life.

The recently updated K/DOQI clinical practice guidelines for vascular access ${ }^{2}$ and the European Best Practice Guidelines on Vascular Access ${ }^{3}$ advocate such surveillance programs. These guidelines state that monitoring for stenosis during dialysis treatment (online monitoring) is preferred compared to Duplex ultrasound or magnetic resonance angiography (MRA) monitoring for practical and economical reasons. Several on-line monitoring tools are available, of which access flow (Qa) monitoring is generally considered as the best surveillance method ${ }^{2-4}$. On-line $\mathrm{Qa}$ evaluation is defined as measurement of access flow using a technique that is inherently linked to the presence of the extracorporeal circulation during hemodialysis treatment. A Qa $<600 \mathrm{ml} / \mathrm{min}$ (AVG), a $\mathrm{Qa}<400 \mathrm{ml} / \mathrm{min}$ (AVF) or a Qa decline $>25 \%$ versus previous measurement (AVG) is an indication for pre-emptive intervention ${ }^{2}$. Whether $Q$ a surveillance can prolong access survival is currently unproven. However, the guidelines state that thrombosis frequency is an important outcome parameter as well. Almost $60 \%$ of patients cite thrombosis of the access as one of the most feared problems associated with hemodialysis vascular access, ranking it second only to pain ${ }^{5}$. Moreover, a dysfunctional access (even before thrombosis occurs) may result in less optimal dialysis ${ }^{6}$.

However, despite guideline recommendations, there is still discussion ${ }^{7-10}$ on the benefits of online Qa surveillance in dialysis patients.

With the help of a systematic literature search we provide an overview of all studies that compared online $\mathrm{Qa}$ surveillance combined with pre-emptive intervention to suggested $^{2,3}$ alternative or conservative surveillance tools and the effect on thrombosis frequency. 


\section{Methods}

An electronic database search was carried out using Medline (Pubmed). As online vascular access flow measurement techniques were not introduced before 1995, the search was limited to the timeframe between January 1995, till September 2007. Search terms were "Vascular access flow OR Vascular access monitoring OR Vascular access surveillance OR Preemptive intervention AND Vascular access thrombosis OR Vascular access occlusion". Only publications in English were included. The outcome measure was the number of occlusions per patient/year. Reference lists from all relevant review articles were searched by hand. All such studies were included that compared none or different surveillance techniques for surveillance with online Qa surveillance. Included participants were male and female adult patients (age $>18$ years) on chronic hemodialysis for end-stage renal disease with both AVG and AVF.

\section{Results}

\section{Description of studies}

Trials identified: In total, 524 articles were retrieved. Four hundred ninety articles were eliminated using title and abstract. The remaining 34 articles were fully assessed and 8 were finally included for the review.

\section{Excluded studies}

A total of 26 studies were excluded after reading the entire manuscript (Table 3.1). The reasons for excluding trials were:

1. review articles $(7)^{7-10,18,27,32}$

2. age of participants $<18$ years $(1)^{19}$

3. analyses focused only on sensitivity of Qa surveillance $(4)^{23,24,29,31}$

4. no online Qa surveillance used $(8)^{13,15,17,20,22,25,26,28}$

5. replication of data from other studies $(1)^{16}$

6. study regarding the effect of percutaneous transluminal angioplasty (PTA) $(1)^{30}$

7. evaluation of AVG which thrombosed despite Qa surveillance (1) ${ }^{11}$

8. study evaluating the relation of high dynamic venous pressure and low $Q$ a in AVG $(1)^{12}$

9. prospective evaluation of AVG patency $(1)^{14}$ and

10. comparison of two online $\mathrm{Qa}$ measurement techniques $(1)^{21}$. 
Table 3.1 Excluded articles after full assessment.

\begin{tabular}{|c|c|}
\hline Study ID & Reason for exclusion \\
\hline Beserab $^{7}$ & Review \\
\hline Paulson ${ }^{8}$ & Review \\
\hline Sands ${ }^{9}$ & Review \\
\hline Work $^{10}$ & Review \\
\hline Arbabzadah $^{11}$ & $\begin{array}{l}\text { Evaluation of AVG that clot despite online Qa surveillance and the outcome of radiological } \\
\text { thrombectomy }\end{array}$ \\
\hline Bosman $^{12}$ & $\begin{array}{l}\text { Study whether high dynamic venous pressure coincides with low AVG flow, measured by the } \\
\text { ultrasound dilution technique }\end{array}$ \\
\hline Cayco $^{13}$ & $\begin{array}{l}\text { Comparison of a surveillance program based on dynamic venous pressure with a historical } \\
\text { group during which no surveillance was applied, in relation to AVG thrombosis incidence }\end{array}$ \\
\hline Cinat $^{14}$ & Evaluation of the patency, complications, and predictive factors of patency for AVG \\
\hline Dember $^{15}$ & $\begin{array}{l}\text { Comparison between prophylactic repair of AVG stenosis based on static venous pressure and } \\
\text { repair at the time of thrombosis, in relation to graft survival }\end{array}$ \\
\hline Dossabhoy $^{16}$ & Replication of data from other study ${ }^{36}$ \\
\hline Frinak $^{17}$ & Sensitivity and specificity of a dynamic venous access ratio test for access surveillance \\
\hline Garland $^{18}$ & Review (Qa measurement by ultrasound dilution the standard of care for access surveillance?) \\
\hline Goldstein $^{19}$ & Age participants $<18$ year \\
\hline Lumsden $^{20}$ & $\begin{array}{l}\text { Prospective randomized trial to compare patients who underwent PTA for AVG (stenosis } \\
>50 \% \text { ) with a control group that received no intervention, towards AVG survival. Surveillance } \\
\text { tool: duplex ultrasound }\end{array}$ \\
\hline Magnesco 21 & Comparison of 2 online Qa measurement techniques \\
\hline Maya $^{22}$ & Comparison of outcomes of elective angioplasty between AVF and AVG \\
\hline Neyra ${ }^{23}$ & Evaluation of the predictive value of $\mathrm{Qa}$ decrease towards thrombosis risk \\
\hline Plantinga $^{24}$ & $\begin{array}{l}\text { Effect of clinic vascular access monitoring practices towards clinical outcomes in hemodialysis } \\
\text { patients. }\end{array}$ \\
\hline Roberts $^{25}$ & $\begin{array}{l}\text { Study towards the value of a surveillance program based on measuring venous resistance, } \\
\text { regarding AVG patency and survival. }\end{array}$ \\
\hline Safa $^{26}$ & $\begin{array}{l}\text { To determine the value of a hemodialysis graft surveillance program in reducing the incidence } \\
\text { of AVG thrombosis and prolonging graft patency by means of preemptive intervention (PTA) of } \\
\text { graft-related stenoses (no online Qa surveillance applied). }\end{array}$ \\
\hline Sands $^{27}$ & Review \\
\hline Sands $^{28}$ & Effect of preemptive intervention towards access survival. No online Qa surveillance used. \\
\hline Singh $^{29}$ & $\begin{array}{l}\text { Comparison predictive accuracy static venous pressure, dynamic venous pressure and access } \\
\text { flow in determining subsequent graft thrombosis }\end{array}$ \\
\hline Tanuma $^{30}$ & Evaluation of the long-term results of vascular access, in particular the effects of PTA. \\
\hline Tessitore $^{31}$ & $\begin{array}{l}\text { Predictive value of online Qa surveillance in AVF towards thrombosis, and sensitivity towards } \\
\text { stenosis detection }\end{array}$ \\
\hline Tonelli $^{32}$ & Review \\
\hline
\end{tabular}

\section{Included studies}

The remaining eight trials and their results are presented in table 3.2. A significant overall ( $A V F$ and $A V G$ ) decline in thrombosis was reported four times ${ }^{33,37,38,40}$. Five trials reported a thrombosis reduction in $\mathrm{AVF}^{34,35,38-40}$, of which two were significant ${ }^{38,40}$. A thrombosis decline in AVG was reported four times ${ }^{34,35,38,40}$, of which one was not significant $^{38}$. An increase in AVG thrombosis was reported once ${ }^{36}$. The first choice for pre-emptive intervention was PTA in all eight trials. PTA was executed in the case of 
stenosis with $\geq 50 \%$ area reduction. Three studies ${ }^{33-35}$ reported surgery used for preemptive intervention when PTA was not feasible. All studies reported an increase in radiological procedures. Despite the significant increase in radiological procedures, two studies $^{35,40}$ reported a cost reduction during the online Qa surveillance period compared to the control group(s).

All studies used the same pre-emptive intervention(s) in the control group and the Qa surveillance group. The referral for intervention used in the control groups was either based on conservative, often not standardized, surveillance parameters (inspection, palpation, auscultation, $\mathrm{Kt} / \mathrm{V})^{39,40}$ or other surveillance tools (venous (static) pressure recordings ${ }^{35,37,38}$ and duplex ultrasound ${ }^{34,36}$ ). The only exception was the study by Hoeben et al. ${ }^{33}$. They compared 2 groups with exactly the same surveillance protocol and in which only one group had pre-emptive intervention. In the control group no timely intervention took place after positive Qa criteria.

\section{Methodological quality of the studies}

The allocation concealment assessment using the Cochrane scoring system revealed two randomized controlled trials with a grade $B$ score (unclear concealment) ${ }^{36,37}$. The remaining 6 trials $^{33-35,38-40}$ were all non-randomized controlled trials (Table 3.2).

\section{Discussion}

Besides the fact that the methodological quality of most of the included studies is not suitable for an adequate statistical analysis of the results presented in table 3.2, there are some other important issues retrieved from the studies which illustrate that an adequate comparison is not possible.

Although seven out of eight studies reported a thrombosis decline using online Qa monitoring, not all of the results were significant. The only trial that reports a higher thrombosis frequency in AVG when compared to the control group ${ }^{36}$ has an important caveat: referral for angiography was only indicated when Qa was less than $600 \mathrm{ml} / \mathrm{min}$, neglecting the 20-25\% Qa decrease. In current guidelines, both the absolute flow and the percentual reduction compared to previous flow measurements are used as indicators for intervention ${ }^{2,3}$. Waiting for $\mathrm{Qa}$ to drop beneath an absolute flow of $600 \mathrm{ml} / \mathrm{min}$ is questionable because a drop $>25 \%$ seems more sensitive towards stenosis compared to an absolute flow less than $600 \mathrm{ml} / \mathrm{min}^{23,29}$. 


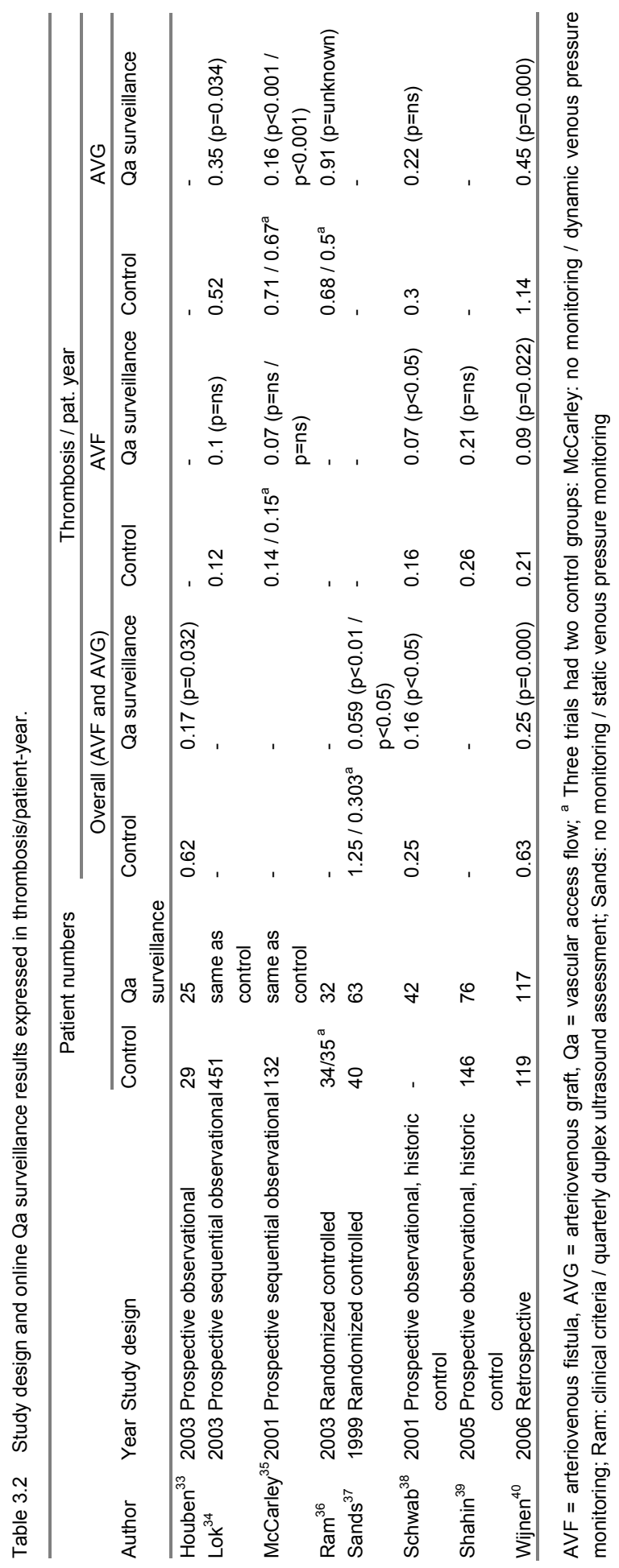


Only a few papers reported the time of measurement during dialysis and none described the haemodynamic circumstances during which Qa was measured. Comparing a Qa result, which is measured during normal blood pressure to a Qa result measured during low blood pressure, may result in a false positive Qa decline (Equation $3.1)^{41}$. In the majority of hemodialysis patients, haemodynamics are far from stable. Rehman et al. ${ }^{42}$ concluded that in the majority of patients Qa measurements can be performed up to 2.5 hours from the start of dialysis treatment, but in patients with a decreased mean arterial pressure (MAP) greater than 15\% these authors advise to perform Qa measurement up to 1.5 hours from the start of dialysis treatment or postpone it to another treatment session, when MAP is more stable.

$$
Q_{a}=\frac{M A P}{R_{a r t}+R_{a a}+R_{\text {graft }}+R_{v a}+R_{v e i n}}
$$

Equation 3.1 Factors influencing access flow $(\mathrm{Q} a)$ in arteriovenous graft.

$\mathrm{MAP}=$ mean arterial pressure, $\mathrm{R}_{\mathrm{ART}}=$ resistance feeding artery, $\mathrm{R}_{\mathrm{AA}}=$ resistance arterial anastomosis, $R_{\mathrm{GRAFT}}=$ resistance graft, $\mathrm{R}_{\mathrm{VA}}=$ resistance venous anastomosis, $\mathrm{R}_{\mathrm{VEIN}}=$ resistance outflow vein

All trials used the reference technique (saline dilution) to measure $\mathrm{Qa}$, however, it is important to realize that using a different and less accurate technique to measure $\mathrm{Qa}$ may cause severe $\mathrm{Qa}$ decline to be missed or unnecessary interventions. The trials that studied reproducibility of different online access flow measurement techniques identified significant differences ${ }^{43,44}$. Considering these differences in accuracy, it is reasonable to imagine that the use of a less accurate $\mathrm{Qa}$ measurement device may result in unnecessary interventions and severe Qa decline to be missed, although no study has yet addressed this issue.

An important advantage of Qa monitoring, i.e. the ability to screen the whole vascular access circuit is often overlooked (Figure 3.1). Only two out of eight retrieved trials ${ }^{33,39}$ reported the segment of the access that was screened during angiography (arterial anastomosis and venous segment). The occurrence of arterial in-flow stenosis is underrecognized and may be the primary problem of $20-30 \%$ of dysfunctional grafts $^{9}$. However, radiological evaluation often primarily focuses on outflow pathology. In a recent study ${ }^{45}$ the value of angiographic evaluation of the whole vascular access circuit was shown. Patients were referred for angiography when Qa was less then $600 \mathrm{ml} / \mathrm{min}$ or Qa decreased by $>25 \%$. Overall inflow stenosis was diagnosed in $77 / 223$ (35\%) of cases (40\% in AVF, 29\% in AVG). Based on these results the authors conclude that angiographic evaluation of access inflow should also be performed if patients are referred based on the results of Qa monitoring. 
Only one study ${ }^{33}$ reported the maximum time (eight weeks) it took to intervene after the reached cut-off value. They reported that five patients developed thrombosis before the scheduled pre-emptive intervention (total number of patients included was 86). In our own unit we schedule patients in the course of a week after positive Qa criteria. Even then, when Qa decline is severe, patients are scheduled in the course of two days for pre-emptive intervention. Although no study has yet addressed this issue, we advocate that intervention should take place in the course of one or two weeks after identification of positive Qa criteria to prevent unnecessary thrombosis.

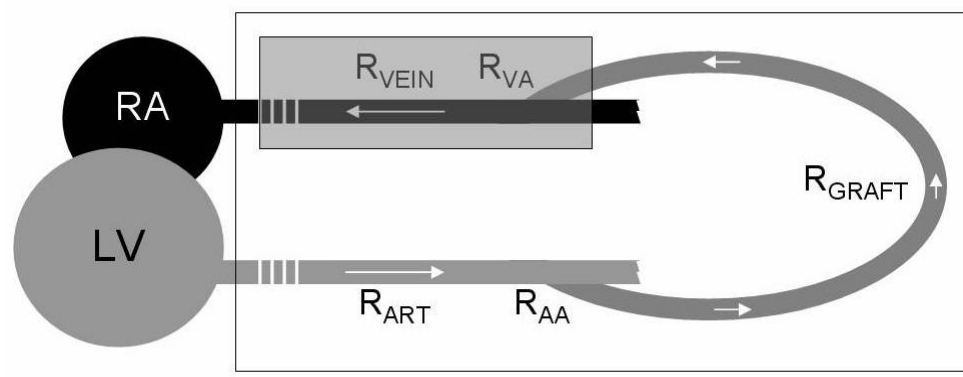

$\square$ Stenosis detection span of control of vascular access flow monitoring
$\square$ Stenosis detection span of control of static intra access pressure ratio monitoring

Figure 3.1 Schematic rendering of resistances in the vascular access graft circuit.

$R A=$ right atrium, $L V=$ left ventricle, $R_{A R T}=$ resistance feeding artery, $R_{A A}=$ resistance arterial anastomosis, $R_{\text {GRAFT }}=$ resistance graft, $R_{V A}=$ resistance venous anastomosis, $R_{V E I N}=$ resistance outflow vein.

\section{Final reflections}

There is of course some evidence and rational supporting the recommendations of the K/DOQI guidelines and the European Best Practice Guidelines that online Qa surveillance is the preferred surveillance tool for stenosis detection when compared to the described alternatives. Although observation of clinical signs (e.g. prolonged bleeding) should not be abandoned, online Qa measurement has been shown to be more accurate in identifying significant stenosis even before clinical symptoms appear $^{23,29}$. Static venous pressure only registers outflow stenosis (Figure 3.1) and has less sensitivity compared to access flow ${ }^{46}$. Recirculation is recognized as a very late finding of stenosis, and therefore is surely not suitable for grafts because these will not remain patent at flows lower than the extracorporeal blood pump speed ${ }^{47}$. 
However, our review identified that, to date, there is no convincing evidence that online Qa surveillance when combined with pre-emptive intervention, has a significant effect on the rate of thrombosis.

To obtain an unambiguous answer through future research, multiple factors need to be in place. These include choice and application of available guidelines and, importantly, successful PTA and/or surgical intervention. Post PTA Qa measurement during angiography evaluates the effect of the intervention and might improve intervention sensitivity ${ }^{48}$. Also, it is known that PTA causes further injury to the vessel wall and may accelerate the disease process of intimal hyperplasia ${ }^{49}$. Alternative therapies in the treatment of intimal hyperplasia might improve vascular access patency. Regarding Qa measurement frequency, it has recently been suggested that frequency should be increased when compared to the suggested monthly measurement ${ }^{50}$.

Another major drawback illustrated by the identified studies is that they are statistically inadequate to account for multiple related factors that include: blood pressure measurement at the time of Qa measurement, angiographic evaluation of the vascular access circuit, time till intervention after positive Qa criteria, patient vascular access prehistory, age of the graft, adequate post PTA flow increase. Also one must take into consideration that most of these factors differ between AVG and AVF. It can be estimated that each group in a randomized controlled trial should have upwards from 200 patients so only a large multi-centre study may provide statistically adequate data.

In conclusion, our review identified that there is no convincing evidence that online $\mathrm{Qa}$ surveillance, when combined with pre-emptive intervention, has a significant effect on the rate of thrombosis. Future large-scale studies with adequate study design, adequate surveillance and intervention protocols and possibly better pre-emptive intervention alternative(s) are necessary. 


\section{References}

1. Rayner HC, Pisoni RL, Bommer J, Canaud B, Hecking E, Locatelli F, Piera L, BraggGresham JL, Feldman HI, Goodkin DA, Gillespie B, Wolfe RA, Held PJ, Port FK. Mortality and hospitalization in hemodialysis patients in five European countries: results from the Dialysis Outcomes and Practice Patterns Study (DOPPS). Nephrol Dial Transplant 2004; 19:108-120.

2. NKF-K/DOQI: Clinical Practice Guidelines for Vascular Access, update 2006. American Journal of Kidney Diseases 2006;48 S1:S176-S2471.

3. Tordoir J, Canaud B, Haage P, Konner K, Basci A, Fouque D, Kooman J, Martin-Malo A, Pedrini L, Pizzarelli F, Tattersall J, Vennegoor M, Wanner C, Ter Wee P, Vanholder R. EBPG on Vascular Access. Nephrol Dial Transplant 2007;22 Suppl 2:ii88-ii117.

4. Lopot F, Nejedly B, Valek M. Vascular access monitoring: Methods and procedures Something to standardize? Blood Purification 2005;23:36-44.

5. Bay $\mathrm{WH}$, Van Cleef $\mathrm{S}$, Owens $\mathrm{M}$. The hemodialysis access: preferences and concerns of patients, dialysis nurses and technicians, and physicians. Am J Nephrol 1998;18:379-383.

6. Hakim RM, Breyer J, Ismail N, Schulman G: Effects of dose of dialysis on morbidity and mortality. Am J Kidney Dis 1994;23:661-669.

7. Besarab A. Access monitoring is worthwhile and valuable. Blood Purif 2006;24:77-89.

8. Paulson WD. Access monitoring does not really improve outcomes. Blood Purif. 2005;23: 50-56.

9. Sands JJ. Vascular access monitoring improves outcomes. Blood Purif 2005;23:45-49.

10. Work J. Does vascular access monitoring work? Adv Ren Replace Ther. 2002;9:85-90.

11. Arbabzadeh M, Mepani B, Murray BM. Why do grafts clot despite access blood flow surveillance? Cardiovasc Intervent Radiol 2002;25:501-505.

12. Bosman PJ, Boereboom FT, Smits HF, Eikelboom BC, Koomans HA, Blankestijn PJ. Pressure or flow recordings for the surveillance of hemodialysis grafts. Kidney Int 1997; 52:1084-1088.

13. Cayco AV, Abu-Alfa AK, Mahnensmith RL, Perazella MA. Reduction in arteriovenous graft impairment: results of a vascular access surveillance protocol. Am J Kidney Dis 1998;32: 302-308.

14. Cinat ME, Hopkins J, Wilson SE. A prospective evaluation of PTFE graft patency and surveillance techniques in hemodialysis access. Ann Vasc Surg 1999;13:191-198.

15. Dember LM, Holmberg EF, Kaufman JS. Randomized controlled trial of prophylactic repair of hemodialysis arteriovenous graft stenosis. Kidney Int 2004;66:390-398.

16. Dossabhoy NR, Ram SJ, Nassar R, Work J, Eason JM, Paulson WD. Stenosis surveillance of hemodialysis grafts by duplex ultrasound reduces hospitalizations and cost of care. Semin Dial 2005;18:550-557.

17. Frinak S, Zasuwa G, Dunfee T, Besarab A, Yee J. Dynamic venous access pressure ratio test for hemodialysis access monitoring. Am J Kidney Dis 2002;40:760-768.

18. Garland JS, Moist LM, Lindsay RM. Are hemodialysis access flow measurements by ultrasound dilution the standard of care for access surveillance? Adv Ren Replace Ther 2002; 9:91-98.

19. Goldstein SL, Allsteadt A, Smith CM, Currier H. Proactive monitoring of pediatric hemodialysis vascular access: effects of ultrasound dilution on thrombosis rates. Kidney Int 2002;62:272-275.

20. Lumsden AB, MacDonald MJ, Kikeri D, Cotsonis GA, Harker LA, Martin LG. Prophylactic balloon angioplasty fails to prolong the patency of expanded polytetrafluoroethylene arteriovenous grafts: results of a prospective randomized study. J Vasc Surg 1997;26: 382-390.

21. Magnasco A, Bacchini G, Cappello A, La Milia V, Brezzi B, Messa P, Locatelli F. Clinical validation of glucose pump test (GPT) compared with ultrasound dilution technology in arteriovenous graft surveillance. Nephrol Dial Transplant 2004;19:1835-1841. 
22. Maya ID, Oser R, Saddekni S, Barker J, Allon M. Vascular access stenosis: comparison of arteriovenous grafts and fistulas. Am J Kidney Dis 2004;44:859-865.

23. Neyra NR, Ikizler TA, May RE, Himmelfarb J, Schulman G, Shyr Y, Hakim RM. Change in access blood flow over time predicts vascular access thrombosis. Kidney Int 1998;54: 1714-1719.

24. Plantinga LC, Jaar BG, Astor B, Fink NE, Eustace JA, Klag MJ, Powe NR. Association of clinic vascular access monitoring practices with clinical outcomes in hemodialysis patients. Nephron Clin Pract 2006;104:c151-159.

25. Roberts AB, Kahn MB, Bradford S, Lee J, Ahmed Z, Fitzsimmons J, Ball D. Graft surveillance and angioplasty prolongs dialysis graft patency. J Am Coll Surg 1996;183:486-492.

26. Safa AA, Valji K, Roberts AC, Ziegler TW, Hye RJ, Oglevie SB. Detection and treatment of dysfunctional hemodialysis access grafts: effect of a surveillance program on graft patency and the incidence of thrombosis. Radiology 1996;199:653-657.

27. Sands JJ. A review of vascular access monitoring techniques: what works best? Nephrol News Issues 2003;17:86-87.

28. Sands J, Miranda CL. Prolongation of hemodialysis access survival with elective revision. Clin Nephrol 1995;44:329-333.

29. Singh N, Ahmad S, Wienckowski JR, Murray BM. Comparison of access blood flow and venous pressure measurements as predictors of arteriovenous graft thrombosis. J Vasc Access 2006; 7:66-73.

30. Tanuma Y. Efficacy of percutaneous transluminal angioplasty in the management of chronic hemodialysis patients. Hinyokika Kiyo 2002;48:593-597.

31. Tessitore N, Bedogna V, Gammaro L, Lipari G, Poli A, Baggio E, Firpo M, Morana G, Mansueto G, Maschio G. Diagnostic accuracy of ultrasound dilution access blood flow measurement in detecting stenosis and predicting thrombosis in native forearm arteriovenous fistulae for hemodialysis. Am J Kidney Dis 2003;42:331-341.

32. Tonelli M. Monitoring and maintenance of arteriovenous fistulae and graft function in hemodialysis patients. Curr Opin Nephrol Hypertens 2004;13:655-660.

33. Hoeben H, Abu-Alfa AK, Reilly RF, Aruny JE, Bouman K, Perazella MA. Vascular access surveillance: evaluation of combining dynamic venous pressure and vascular access blood flow measurements. Am J Nephrol 2003;23:403-408.

34. Lok CE, Bhola C, Croxford R, Richardson RM. Reducing vascular access morbidity: a comparative trial of two vascular access monitoring strategies. Nephrol Dial Transplant 2003; 18:1174-1180.

35. McCarley P, Wingard RL, Shyr Y, Pettus W, Hakim RM, Ikizler TA. Vascular access blood flow monitoring reduces access morbidity and costs. Kidney Int 2001;60:1164-1172.

36. Ram SJ, Work J, Caldito GC, Eason JM, Pervez A, Paulson WD. A randomized controlled trial of blood flow and stenosis surveillance of hemodialysis grafts. Kidney Int 2003;64: 272-280.

37. Sands JJ, Jabyac PA, Miranda CL, Kapsick BJ. Intervention based on monthly monitoring decreases hemodialysis access thrombosis. ASAIO J 1999;45:147-150.

38. Schwab SJ, Oliver MJ, Suhocki P, McCann R. Hemodialysis arteriovenous access: detection of stenosis and response to treatment by vascular access blood flow. Kidney Int. 2001;59:358-362.

39. Shahin H, Reddy G, Sharafuddin M, Katz D, Franzwa BS, Dixon BS. Monthly access flow monitoring with increased prophylactic angioplasty did not improve fistula patency. Kidney Int. 2005;68:2352-2361.

40. Wijnen E, Planken N, Keuter X, Kooman JP, Tordoir JH, de Haan MW, Leunissen KM, van der Sande F. Impact of a quality improvement programme based on vascular access flow monitoring on costs, access occlusion and access failure. Nephrol Dial Transplant 2006;21: 3514-3519.

41. Schneditz D, Fan Z, Kaufman A, Levin NW. Stability of access resistance during hemodialysis. Nephrol Dial Transplant 1998;13:739-744.

42. Rehman SU, Pupim LB, Shyr Y, Hakim R, Ikizler TA. Intradialytic serial vascular access flow measurements. Am J Kidney Dis 1999;34:471-477. 
43. Lopot F, Nejedly B, Sulkova S, Blaha J: Comparison of different techniques of hemodialysis vascular access flow evaluation. Int J Artif Organs 2003;26:1056-1063.

44. Wijnen E, Essers S, van Meijel G, Kooman JP, Tordoir J, Leunissen KM, van der Sande FM. Comparison between two on-line reversed line position hemodialysis vascular access flow measurement techniques: saline dilution and thermodilution. ASAIO J 2006;52:410-415.

45. Asif A, Gadalean FN, Merrill D, Cherla G, Cipleu CD, Epstein DL, Roth D. Inflow stenosis in arteriovenous fistulas and grafts: a multicenter, prospective study. Kidney Int. 2005;67: 1986-1992.

46. Spergel LM, Holland JE, Fadem SZ, McAllister CJ, Peacock EJ. Static intra-access pressure ratio does not correlate with access blood flow. Kidney Int 2004;66:1512-1516.

47. Wijnen E, van der Sande FM, Kooman JP, Leunissen KM. Vascular access recirculation: setting a new detection method in the context of the overall utility of detection. Nat Clin Pract Nephrol 2007;3:252-253.

48. Krivitski NM. Access flow measurement during surveillance and percutaneous transluminal angioplasty intervention. Semin Dial 2003;16:304-308.

49. Ikizler TA, Himmelfarb J. Trials and trade-offs in hemodialysis vascular access monitoring. Nephrol Dial Transplant 2006;21:3362-3363.

50. White JJ, Ram SJ, Jones SA, Schwab SJ, Paulson WD. Influence of luminal diameters on flow surveillance of hemodialysis grafts: insights from a mathematical model. Clin J Am Soc Nephrol 2006;1:972-978. 



\section{Chapter 4}

Comparison between two on-line reversed line position hemodialysis vascular access flow measurement techniques; saline dilution and thermodilution

E Wijnen, S Essers, G van Meijel, JP Kooman, J Tordoir, KML Leunissen, FM van der Sande 


\section{Abstract}

\section{Introduction}

Periodical access flow measurements can predict the development and presence of vascular access flow-limiting stenosis and subsequent thrombosis. Access flow measurement has become a standard in vascular access care. Different techniques to measure access flow are available. The aim of this study was to compare an integrated access flow measurement device, based on thermodilution (BTM ${ }^{\circledast}$, Fresenius Medical Care, Bad Homburg, Germany), with the 'gold standard', the $\mathrm{HDO1}^{\circledR}$ (Transonic Systems Inc., Ithaca, NY), which technique is based on saline dilution.

\section{Methods}

In 40 end stage renal disease (ESRD) patients 40 vascular accesses were studied to determine the correlation between access flow measurements by both techniques. Reproducibility of access flow measurements by both techniques was assessed in twenty patients with a weekly interval.

\section{Results}

A total of 40 measurement series were performed. Average access flow measured with the saline dilution technique and the thermodilution technique was $1053(+/-495) \mathrm{ml} / \mathrm{min}$ and $1034(+/-527) \mathrm{ml} / \mathrm{min}$ respectively $(\mathrm{p}=0.628) \quad(\mathrm{N}=40)$. Correlation between access flow measurements by both techniques expressed in $R^{2}$ was $0.79(r=0.89)$.

Reproducibility of saline and thermodilution subsequent measurements with a weekly interval, expressed in relative difference $\left(\Delta \mathrm{X}_{\text {rel }}\right)$ was $13(+/-11) \%$ and $24(+/-14) \%$ respectively $(p<0.01)$ $(\mathrm{N}=20)$.

\section{Conclusion}

BTM access flow measurements correlated well with the HD01 access flow measurements. However the better reproducibility of HD01 and shorter measurement time compared to BTM access flow measurements should be considered when implementing access flow measurement to prevent vascular access failure. 


\section{Introduction}

Numerous studies have pointed out that periodical access flow measurements can predict the development and presence of vascular access flow-limiting stenosis and subsequent thrombosis. Pre-emptive intervention (either radiological or surgical) extend the duration of access sites and may even reduce health care $\operatorname{costs}^{1-5}$, although because of recent negative trials, this issue has become more controversial ${ }^{6}$. The Kidney Disease Outcome Quality Initiative (K/DOQI) clinical practice guidelines for Vascular Access strongly recommend surveillance of vascular access monitoring by periodical flow measurements ${ }^{7}$. Most common used technique to measure access flow is the saline dilution technique as introduced by Krivitski ${ }^{8}$.

Recently it has become possible to perform access flow measurements during dialysis treatment with devices which can be integrated in the dialysis machine itself. The Blood Temperature Monitor $\left(\right.$ BTM $^{\circledR}$, Fresenius Medical Care, Bad Homburg, Germany) integrated in the $4008 \mathrm{H}$ dialysis machine (Fresenius Medical Care, Bad Homburg, Germany) measures access flow based on temperature dilution.

Great practical advantage of the BTM compared to the $\mathrm{HDO1}^{\circledR}$ (Transonic Systems Inc., Ithaca, NY), is the integration with the dialysis machine which offers the opportunity to measure numerous patients simultaneously. However, except for two studies, the agreement between thermodilution and saline dilution and variability of thermodilution has not been widely studied in a larger population.

The aim of the present study was therefore, first to analyse the agreement between the results of both measurement techniques, and, second, to determine the reproducibility of each separate measurement technique.

\section{Patients and methods}

\section{Protocol}

Measurements were performed during the first hour of dialysis treatment in 40 endstage renal disease (ESRD) patients. Forty vascular accesses (16 forearm fistula, 13 forearm grafts, 10 upper arm fistula, 1 upper arm graft) were studied. For each study a series of measurements were performed: (1) access recirculation (normal blood line position) and (2) access flow (reversed blood line position) were measured using the saline dilution technique; (3) access flow was measured using the BTM. Access flow measurement using the BTM consists out of two recirculation measurements. One with correct placement of bloodlines and one with reversed bloodlines. With the use of an access flow measurement protocol supplied by the manufacturer, a second recirculation 
measurement with correct placement of bloodlines was performed. A spreadsheet document was used to calculate access flow with help of an embedded formula (equation 3). The spreadsheet data presented two access flow values that were averaged.

Before each access flow measurement blood pressure was measured. With each HD01 and BTM measurement blood pump speed was set at $300 \mathrm{ml} / \mathrm{min}$.

Twenty of above described accesses were studied twice with a weekly interval.

\section{Analysis techniques}

Both techniques to measure access flow, are based on reversed line position. The purpose of reversed line position is to enable delivery of indicator into the venous dialyser line upstream of the access, and then to be able to sample downstream of the access (after the indicator has mixed) in the arterial line.

Measuring access flow with the use of the Transonic HD01, a bolus of isotonic saline (indicator) is administrated in the venous bubble trap after line reversal. The administration time has to be less than six seconds to prevent cardiopulmonary recirculation. Two ultrasound dilution sensors are clamped onto the bloodlines, one on the arterial and one on the venous bloodline. The venous saline dilution sensor will first sense the diluted blood (ultrasound velocity blood: $1560-1590 \mathrm{~m} / \mathrm{s}$, isotonic saline $0,9 \%$ : $1533 \mathrm{~m} / \mathrm{s}$ ), which is a reference value to calculate the actual recirculation, which is what is left of the dilution in the arterial line, after passing the access (Figure 4.1).

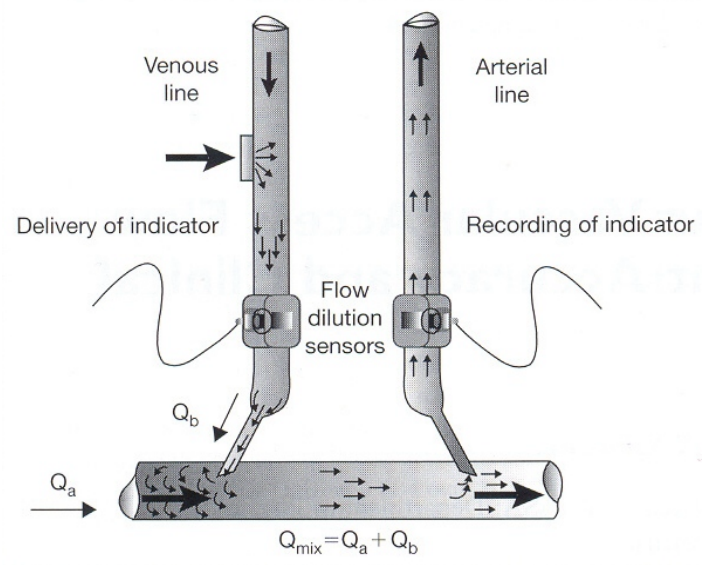

Figure 4.1 HD01 reversed lines access flow measurement setup. 
Besides sensing dilution, the saline dilution sensors simultaneously measure blood flow in the bloodlines. The obtained recirculation fraction $(R)$ and measured extracorporeal blood flow $\left(Q_{b}\right)$ provide the possibility to calculate access flow $\left(Q_{a}\right)$ according to equation 1.

Equation 4.1

$$
Q_{a}=Q_{b} \times\left[\frac{1-R}{R}\right]
$$

Recirculation measurement with the saline dilution technique is performed with normal extracorporeal line position. The administered bolus of isotonic saline in the venous bubble trap will disappear upstream of the access. However, when vascular access recirculation appears a fraction of the administered saline will be sensed in the arterial line.

Instead of fluid dilution the BTM uses temperature as indicator through dialysate temperature to heat up or cool down the returning blood to the patient. Temperature is registered by two temperature sensors which are placed around the venous and arterial bloodline, both located one meter from the access. When the blood temperature downstream the artificial kidney drops or raises, the change in temperature will be registered by the sensor placed around the venous bloodline. This same temperature change will affect the temperature of the central blood volume when it enters the patient's bloodstream. Through cardiopulmonary recirculation the extracorporeal induced temperature change will be sensed by the temperature sensor clamped around the arterial bloodline (Figure 4.2.). At the end of the measurement the difference between the venous and arterial bloodline temperatures is displayed on the BTM monitor as a relative value and stands for the temperature recirculation $\left(R_{B T M, n}\right)$, caused by cardiopulmonary recirculation. The relative recirculation value obtained by executing this measurement with reversed bloodlines $\left(R_{B T M}\right)$, includes both the recirculation over the access and the cardiopulmonary recirculation, due to measurement time which takes approximately five minutes and is technique dependant. To separate the cardiopulmonary induced temperature recirculation from the recirculation fraction over the access, the ratio of access flow to cardiac output has to be defined using the "double recirculation technique" ${ }^{\text {"9 }}$ and stands for the actual cardiopulmonary recirculation (CPR):

Equation 4.2

$$
C P R=\frac{R_{B T M, n}\left(1-R_{B T M, x}\right)}{R_{B T M, x}\left(1-R_{B T M, n}\right)} \cdot \frac{Q_{b, x}-\frac{U F_{\text {rate }}}{60}}{Q_{b, n}}
$$

where $Q_{b, n}$ is the extra corporeal blood flow with normal line position, and $Q_{b, x}$ the extra corporeal blood flow with reversed line position. $Q_{b}$ is displayed on the $4008 \mathrm{H}$ dialysis 
machine main display and represents the operator's set up extracorporeal pump speed corrected for the arterial pressure. Afterwards $Q_{b}$ is also corrected for the ultrafiltration rate $\left(\mathrm{Uf}_{\text {rate }} / 60\right)$. Eventually access flow is calculated using equation three, which is based on equation one embedded with the above described corrections.

Equation 4.3

$$
Q_{a}=\left(Q_{b, x}-\left(\frac{\text { UFrate }}{60}\right)\right)\left(\frac{1-R_{B T M, x}}{R_{B T M, x}\left(1-\left(\frac{R_{B T M, n}\left(1-R_{B T M, x}\right)}{R_{B T M, x}\left(1-R_{B T M, n}\right)} \cdot \frac{Q_{b, x}-\frac{\text { UFrate }}{60}}{Q_{b, n}}\right)\right)}\right)
$$

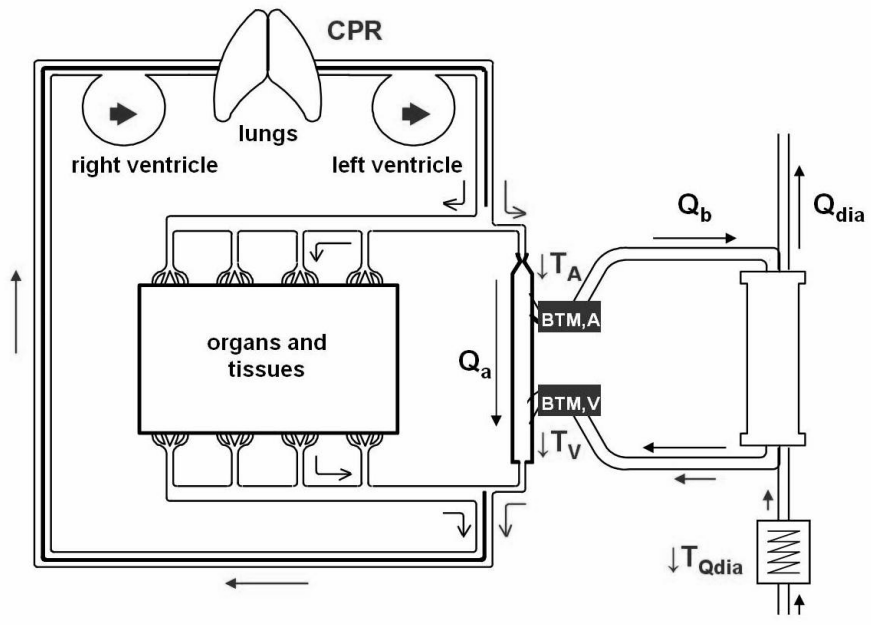

Figure 4.2 BTM CPR measurement setup.

$Q_{a}=$ access flow, $Q_{b}=$ extracorporeal blood flow, $Q_{d i a}=$ dialysate flow, $T_{v}=$ temperature in the venous bloodline, $\mathrm{T}_{\mathrm{a}}$ =temperature in the arterial bloodline, $\mathrm{T}_{\text {Qdia }}=$ temperature of the dialysate, $\mathrm{CPR}=$ cardiopulmonary recirculation, $\mathrm{BTM}, \mathrm{A}=$ arterial temperature sensor head, $\mathrm{BTM}, \mathrm{V}=$ venous temperature sensor head. This figure shows the measurement of the cardiopulmonary recirculation measurement. The dialysate heater initiates a drop in temperature $\left(\mathrm{T}_{\text {Qdia }}\right)$. Following the arrows this temperature drop has effect on the temperature in the venous line $\left(T_{v}\right)$. Through cardiopulmonary recirculation (CPR), the extracorporeal induced temperature drop is reflected at the BTM,A $\left(T_{a}\right)$. Finally the relation of the temperature drops measured by arterial and venous sensor heads is equivalent to the percentage recirculation of blood flow. Executing this measurement with reversed bloodlines includes both the recirculation over the access (comparable with the saline dilution technique) and the cardiopulmonary recirculation, due to long measurement time. 


\section{Dialysis strategy}

Thirty-one patients were treated with bicarbonate hemodialysis with low flux polysulfone membranes (F8HPS; Fresenius; Bad Homburg; Germany). Nine patients were treated with on-line postdilution hemodiafiltration (HDF) with high flux membranes (APS-1050, Asahi Medical Co., Tokyo, Japan). Postdilution HDF probably has no effect on BTM measurement, as the substitution fluid is from the same source as the dialysate. Changing the dialysate temperature also affects the substitution fluid temperature in the same way. Using the Transonic HD01, infusion of substitution fluid was temporarily stopped because the infusion fluid during HDF was infused in post-dilution mode. The venous ultrasound signal is disturbed due to pulsatile fluid infusion, which yields errors in the measurement.

Sodium concentration of the dialysate was 138 or $140 \mathrm{mmol} / \mathrm{l}$, calcium concentration was $1.5 \mathrm{mmol} / \mathrm{l}$ and temperature of the dialysate was 36 or $36.5^{\circ} \mathrm{C}$. Ultrapure dialysate was used, achieved by double reverse osmosis, electric deionisation, ozone sanatisation and filtration through Diasafe ${ }^{\circledR}$ (Fresenius; Bad Homburg; Germany).

\section{Statistical analysis}

Statistical analysis was performed using SPSS 12.0 software. The relation between $\mathrm{Q}_{\mathrm{a}(\mathrm{HD} 01)}$ and $\mathrm{Q}_{\mathrm{a}(\mathrm{BTM})}$ was studied using regression analysis and Bland Altman plot. The reproducibility of both techniques was assessed by analysing the relative difference of weekly subsequent measurements: $\Delta X_{\text {rel }}=\sqrt{ }\left(\left(X_{2} / X_{1}-1\right)^{2}\right)$. Data are given as mean $\pm S D$ values. A value of $p<0.05$ is considered significant.

\section{Results}

\section{Agreement between both techniques}

Average access flow measured with the saline dilution technique and the thermodilution technique was $1053(+/-495) \mathrm{ml} / \mathrm{min}$, and $1034(+/-527) \mathrm{ml} / \mathrm{min}$ respectively $(p=0.628)$ $(\mathrm{N}=40)$. Correlation between access flow measurements by both techniques expressed in $r^{2}$ was $0.79(r=0.89)$ (Figure 4.3 and 4.4). 


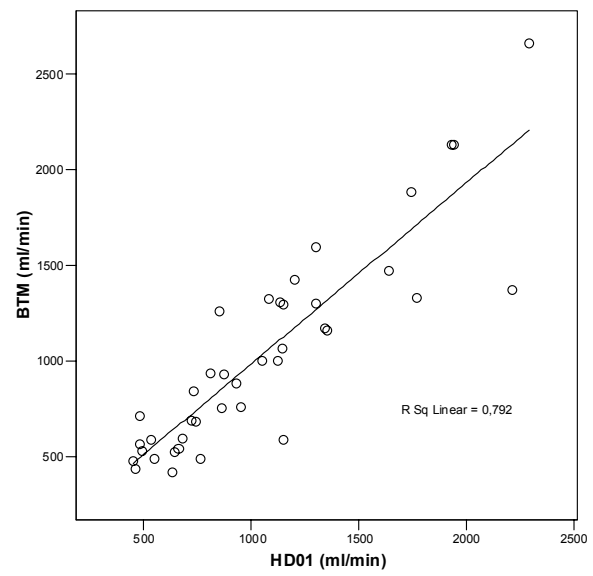

Figure 4.3 Scatter plot $Q_{a}$ results saline dilution (HD01) vs thermodilution (BTM).

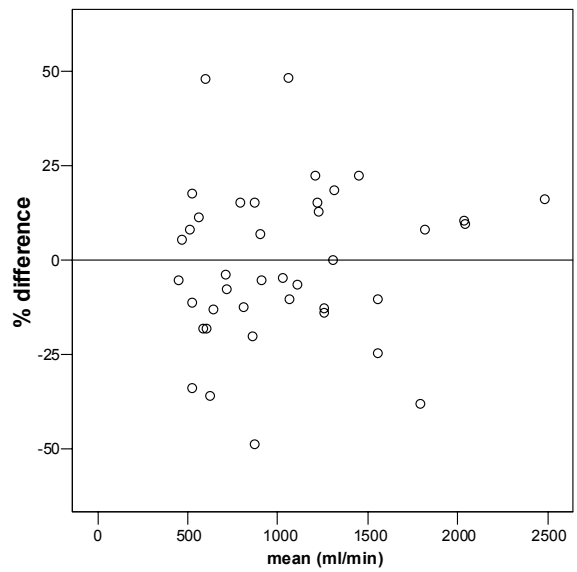

Figure 4.4 Bland Altman $Q_{a}$ results saline dilution (HD01) vs thermodilution (BTM).

\section{Reproducibility results of each separate technique}

Reproducibility of saline and thermodilution subsequent measurements with a weekly interval, expressed in relative difference $\left(\Delta X_{\text {rel }}\right)$ was $13(+/-11) \%$ and $24(+/-14) \%$ respectively $(p<0.01)(N=20)$.

Reproducibility results of saline and thermodilution subsequent measurements are also displayed with help of a Bland Altman analysis in Figure 4.5 and Figure 4.6 respectively. 


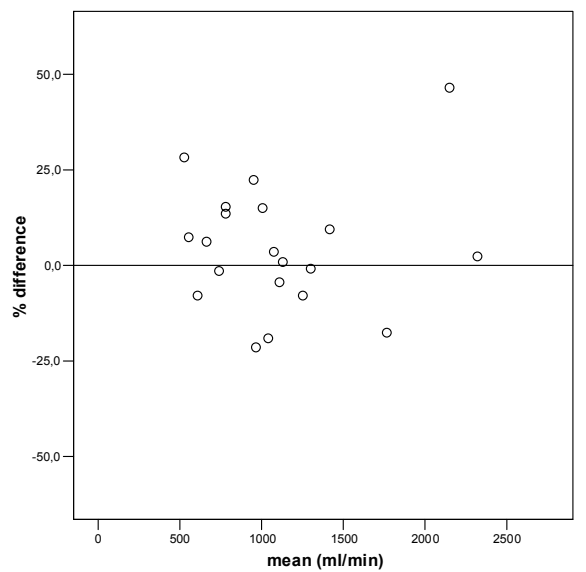

Figure 4.5 Bland Altman HD01 Qa measurement 1 vs HD01 Qa measurement 2.

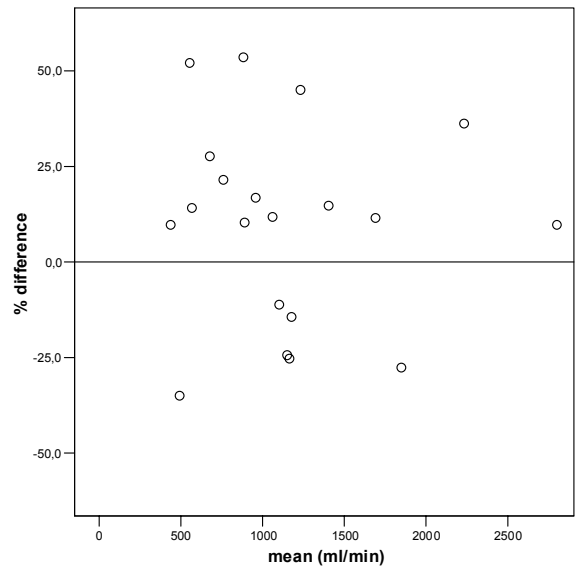

Figure 4.6 Bland Altman BTM Qa measurement 1 vs BTM Qa measurement 2.

Saline dilution technique's correlation expressed in $r^{2}$ of subsequent measurements was $0.82(r=0.91)$. Thermodilution technique's $r^{2}$ of subsequent measurements was 0.79 ( $r=0.89$ ) (Figure 4.7). 


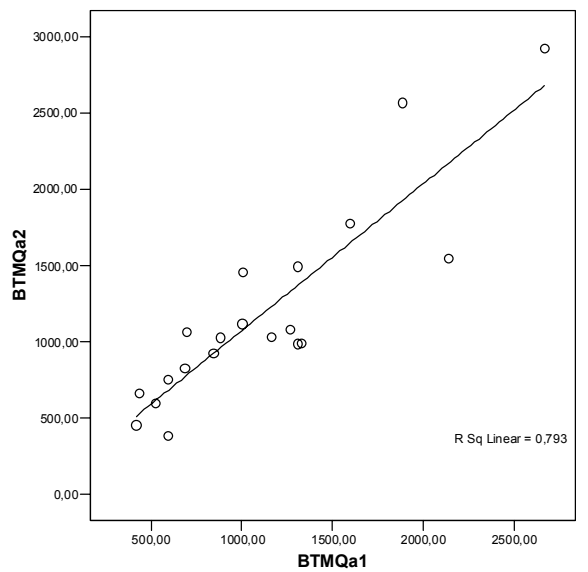

Figure 4.7 Scatter plot Repeated BTM Qa results with weekly interval.

\section{Access recirculation}

The measured access recirculation fraction was $0 \%$ in all separate recirculation measurements done with the saline dilution method $(\mathrm{N}=40)$. Access recirculation obtained with the thermodilution technique had to be calculated with help of equation 4.4 which is described elsewhere ${ }^{9}$.

Equation 4.4

$$
R_{\text {access }}=R_{B T M, n}-\left(\frac{C P R\left(\frac{Q_{b}}{Q_{a}}\right)}{1-C P R\left(1-\left(\frac{Q_{b}}{Q_{a}}\right)\right)}\right)
$$

Thermodilution mean access recirculation result was $0.74(+/-0.46) \%(\mathrm{~N}=40)$.

\section{Additional results}

The mean relative difference between $Q_{b}$ values measured with both techniques was $5.1(+/-3) \%(\mathrm{~N}=40)$.

The mean relative difference of BTM recirculation measurements with normal line position $\left(\mathrm{R}_{\mathrm{BTM}, \mathrm{n}}\right)$, measured before and after each reversed line recirculation measurement, was $27(+/-25) \%(\mathrm{~N}=40)$. Average absolute value for the first and second BTM recirculation measurement with normal line position was $8.2(+/-2.6) \%$ and $7.0 \pm 2.7(\mathrm{~N}=40) \%$, respectively $(\mathrm{p}<0.001)$. The inter-treatment reproducibility for recirculation with normal bloodline position was $30.3(+/-21.4) \%(\mathrm{~N}=20)$. Average 
absolute values for these measurements were $8.4(+/-2.3)$ and $7.0(+/-2.8) \quad(\mathrm{N}=20)$, respectively $(p=0.073)$.

Average measurement time to calculate $Q_{a}$ with the HD01 took 4(+/-0.5) minutes. Average measurement time in order to calculate $Q_{a}$ with the BTM based on only one $\mathrm{R}_{\mathrm{BTM}, \mathrm{n}}$ measurement took 29(+/-7) minutes.

The mean arterial pressure (MAP) values at which the reproducibility testings were performed for saline dilution $Q_{a}$ measurement were $88.8(+/-18.0) \mathrm{mmHg}$ (week 1) and $90.2(+/-17.7) \mathrm{mmHg}$ (week 2$)$, respectively $(\mathrm{p}=\mathrm{ns})(\mathrm{N}=20)$.

The MAP values at which the reproducibility testings were performed for temperaturedilution access flow measurements were $84.4(+/-15.2) \mathrm{mmHg}$ (week 1) and 86.1(+/-17.0) $\mathrm{mmHg}($ week 2$)$, respectively $(\mathrm{p}=\mathrm{ns})(\mathrm{N}=20)$.

\section{Discussion}

In this study we showed a good correlation, but wide limits between the thermo dilution technique and the saline dilution technique. However reproducibility was less with the thermodilution technique compared to the saline dilution technique.

To best of our knowledge only two papers studied correlation between both techniques: The Schneditz et al. ${ }^{10}$ validation report of the thermodilution technique showed a similar correlation ( $r^{2}=0.84, N=52$ in 17 patients) compared to this study: $r^{2}=0.79$ ( $N=40$ in 40 patients). Lopot et al. ${ }^{11}$ found a higher correlation between both techniques expressed in $r=0.9543\left(r^{2}=0.91, n=54\right.$, number of patients: unknown).

Reproducibility of the separate techniques is also described in the Lopot study: a correlation coefficient of $0.9197\left(r^{2}=0.85\right)$ and $0.9702\left(r^{2}=0.94\right)$ in 40 subsequent thermodilution measurements and in 58 subsequent saline dilution measurements respectively, compared to this study, $r=0.89\left(r^{2}=0.79, N=20\right)$ and $r=0.91\left(r^{2}=0.82, N=20\right)$. Ragg et al. ${ }^{12}$ studied within treatment reproducibility of the thermodilution technique ( $n=189$ in 56 patients). Correlation between repeated Qa measurements was rather low $(r=0.68)$. They concluded that reproducibility lessened considerably with increasing magnitude of flow rate $(\geq 600 \mathrm{ml} / \mathrm{min})$. In our study, the variation between subsequent thermodilution measurements with a weekly interval appeared to be present in every flow range (Figure 4.6). Possibly, the long thermodilution measurement time, compared to the saline dilution method may play a role in reduced reproducibility considering that variable haemodynamic conditions are present during dialysis treatment ${ }^{13,14}$. To prevent variable haemodynamic conditions in this study, reproducibility measurements were executed in two separate dialysis sessions at the very same time (start of measurement series 5 till 10 minutes after start dialysis treatment). The MAP values at which the reproducibility testings were performed were identical between week 1 and week 2 
$(88.8(+/-18.0) \mathrm{mmHg}$ versus $90.2(+/-17.7) \mathrm{mmHg}$ for saline dilution measurements and $84.4(+/-15.2) \mathrm{mmHg}$ versus $86.1(+/-17.0) \mathrm{mmHg}$ for BTM measurements). Thus, differences in MAP do not appear to have played a role in apparent differences in reproducibility of the measurements. However, the small difference in MAP values between saline dilution and temperature dilution measurements might have played some role in the lesser agreement between both methods.

Of course the differences in measurement techniques might also influence the separate reproducibility results. The two most important differences can be illustrated using equation one. To calculate $Q_{a}$, two independent values have to be measured: $Q_{b}$ and the reversed lines access recirculation $\left(R_{, x, \text { access }}\right) . Q_{b}$ is measured using the HD01 whereas the BTM technique has to estimate true $Q_{b}$ as described before. However the described mean relative difference between both $Q_{b}$ 's $(5.1(+/-3) \%)$, is not significant.

$R_{x, \text { access }}$ is also directly measured using the HD01 and has to be calculated when using the BTM technique which needs two separate recirculation measurements (normal and reversed lines) to correct for the cardiopulmonary recirculation. The frailty of this calculated approximation of $R_{x, \text { access }}(B T M)$ can be illustrated showing the mean relative difference of subsequent $R_{B T M, n}$ results, measured before and after each reversed line recirculation measurement, and the inter treatment subsequent $R_{B T M, n}$ results, which was $27(+/-25) \%$ and $30.3(+/-21.4) \%$, respectively. Lopot et al. ${ }^{11}$ described that when CPR is neglected it will significantly underestimate actual $Q_{a}$ values up to $30 \%$.

\section{Access recirculation}

Access recirculation measured with the saline dilution technique was $0 \%$ in all patients. Mean access recirculation obtained with the thermodilution technique was practically comparable: $0.74(+/-0.46) \%(\mathrm{~N}=40)$

Wang et al. ${ }^{15}$ described that a BTM recirculation with normal blood lines above a threshold of $15 \%$ has been found as highly sensitive and specific for access recirculation. In this study only one patient had a recirculation value larger than $15 \%$ (15.2\%). In this patient, access flow was normal $(1150 \mathrm{ml} / \mathrm{min}$ (saline dilution method) and $565 \mathrm{ml} / \mathrm{min}$ (temperature dilution method)) and no access recirculation was found by the saline and the temperature dilution technique.

\section{Implications for clinical practice}

The reproducibility of the saline dilution and thermodilution technique mentioned in both previous described studies ${ }^{11,12}$ are not expressed in relative difference $\left(\Delta \mathrm{X}_{\text {rel }}\right)$.

The average relative difference of the thermodilution technique $(24(+/-14) \%)$ described in our study almost identifies with the call to intervene, knowing the $25 \%$ access flow 
decline as advised by K/DOQI Clinical Practical Guidelines for Vascular Access ${ }^{7}$ and the European Guidelines ${ }^{16}$. This could lead to unnecessary intervention based on false measurement, or missing of severe access flow decline (Figure 4.5).

Of course we should not forget the relative difference of the saline dilution technique $\left(\Delta X_{\text {rel }}=13(+/-11) \%\right)$, which however less compared to the relative difference of the thermodilution technique, is still significant. With the saline dilution technique it is possible though to measure $Q_{a}$ three times in a row within a short moment of time (5 to 7 minutes) hereby minimizing the effect of variable haemodynamics. Averaging these three results will partly reduce the measurement variation of the saline dilution technique. To measure $Q_{a}$ once with the BTM technique using the described protocol took an average time of $29(+/-7)$ minutes.

\section{Conclusion}

Considering the fact that the BTM was initially designed to obtain cardiovascular stability during dialysis, the thermodilution measurements correlate well with the saline dilution measurements. However, access flow is measured to prevent vascular access failure and of course accuracy is an issue here. The saline dilution technique's better reproducibility results and the shorter measurement time should be considered when access flow measurement plays a vital role within the local vascular surveillance program. 


\section{References}

1. McCarley P, Wingard RL, Shyr Y, Pettus W, Hakim R, Ikizler TA. Vascular access blood flow monitoring reduces access morbidity and costs. Kidney Int 2001;60:1164-1172.

2. Schwab S, Oliver M, Suhocki P, McCann R. Hemodialysis arteriovenous access: Detection of stenosis and response to treatment by vascular access blood flow. Kidney Int 2001;:59:358-362.

3. Valj K. Prophylactic angioplasty: Is it worthwhile?; in Gray RJ, Sands JJ (eds). Dialysis Access: A Multidisciplinary Approach. Philadelphia, Lippincott Williams \& Wilkins 2002; 153-156.

4. Sands J, Jabyac P, Miranda C, Kapsick B. Intervention based on monthly monitoring decreases hemodialysis access thrombosis. ASAIO J 1999;45:147-150.

5. Sands J. Vascular access monitoring improves outcomes. Blood Purification 2005;23:45-49.

6. Paulson WD. Access monitoring does not really improve outcomes. Blood Purif 2005;23: 50-56.

7. NKF-K/DOQI. Clinical practice guidelines for vascular access: Update 2000. Am J Kidney Dis 2001;37:S137-S181.

8. Krivitski NM. Theory and validation of access flow measurement by dilution technique during hemodialysis. Kidney Int 1995;48:244-250.

9. Schneditz D, Fan Z, Kaufman AM, Levin NW. Measurement of access flow during dialysis using the constant infusion approach. J Am Soc Artif Intern Org 1998;44:74-81.

10. Schneditz D, Wang E, Levin W. Validation of hemodialysis recirculation and access blood flow measured by thermodilution. Nephrol Dial Transplant 1999;14:376-383.

11. Lopot F, Nejedly B, Sulkova S, Blaha J. Comparison of different techniques of hemodialysis vascular access flow evaluation. Int J Artif Organs. 2003;26:1056-1063.

12. Ragg JL, Treacy JP, Snelling P, Flack M, Anderton S. Confidence limits of arteriovenous fistula flow rate measured by the 'on-line' thermodilution technique. Nephrol Dial Transplant 2003;18:955-960.

13. Besarab A, Lubkowski T, Vu A, Aslam A, Frinak S. Effects of Systemic Hemodynamics on Flow within Vascular Accesses Used for Hemodialysis. ASAIO Journal. 2001;47:501-506.

14. Rehman SU, Pupim LB, Shyr Y, Hakim R, Ikizler TA. Intradialytic serial vascular access flow measurements. Am J Kidney Dis 1999;34:471-477.

15. Wang E, Schneditz D, Kaufman AM, Levin NW. Sensitivity and specificity of the thermodilution technique in detection of access recirculation. Nephron 2000;85:134-141.

16. Management of the renal patient: Clinical algorithms on vascular access for hemodialysis. Lengerich; Berlin; Bremen; Miami; Riga; Viernheim; Vienna; Zagreb: Pabst Science Publishers, 2003. ISBN 3-936142-86-6. 


\section{Chapter 5}

\section{Measurement of hemodialysis vascular access flow using extracorporeal temperature gradients}

E Wijnen, FM van der Sande, JP Kooman, T de Graaf, JHM Tordoir, KML Leunissen, D Schneditz 


\section{Abstract}

\section{Introduction}

A reduction in vascular access flow poses a risk for thrombosis. We present a new technique to measure vascular access flow during dialysis based on extracorporeal temperature gradients, and their changes, on reversing the extracorporeal blood lines without having to inject an indicator.

\section{Methods}

Fistula temperatures were measured by the blood temperature monitor with normal line position and after manual switching of the blood lines using the same extracorporeal blood flow. The access flow by our Temperature Gradient Method (TGM) was compared to access flow derived by saline dilution with measurements in the same patients repeated in subsequent weeks.

\section{Results}

In seventy pairs of TGM and saline dilution measurements in 35 patients, the repeatability of the TGM measurements was not significantly different from that of saline dilution. There was a highly significant correlation between the two techniques with an acceptable confidence level for limits of agreement for the difference between them. It took about 9 minutes to complete the TGM method and about 5 minutes for saline dilution.

\section{Conclusion}

Our studies show that the novel TGM method showed excellent agreement and reproducibility with the saline dilution method without the need for indicator dilution. 


\section{Introduction}

A drop of vascular access flow $\left(Q_{a}\right)$ by $25 \%$ or a fall below $600 \mathrm{ml} / \mathrm{min}$ is considered indicative of pending thrombosis which should trigger intervention in order to prevent access thrombosis ${ }^{1}$.

There are several techniques to measure $Q_{a}$ in dialysis patients during dialysis and most of them are based on principles of indicator dilution. The measurement by indicator dilution requires the reversal of extracorporeal blood lines, the injection of a suitable indicator such as isotonic saline into the line returning blood to the access, and measurement of the dilution curve in the line drawing blood from the access. The saline dilution technique using reversed placement of blood lines has been developed by Krivitski $^{2}$ approximately ten years ago. More recently, the use of thermodilution in access flow monitoring has been introduced ${ }^{3}$. A good agreement between the thermodilution and the saline dilution technique was recently reported, although the repeatability of saline dilution appeared to be superior to thermodilution ${ }^{4}$.

However, the major disadvantage of current techniques is that they either require manual injection of the indicator (saline dilution) or that they are slow and time consuming (thermodilution). The thermodilution technique requires two measurements with correct and reversed placement of blood lines, the algorithms require stability, and the injection of the thermal indicator (based on changes in dialysate temperature) takes a few minutes so that the whole procedure may take up to 30 minutes. Approximately half of that time the blood lines are placed in reversed position. This is too long for everyday measurements, especially since solute clearance and treatment efficiency are reduced in the setting where blood flow is reversed. Moreover, the relatively long time needed for thermodilution measurements might play a role for its reduced reproducibility when compared to saline dilution ${ }^{4}$. The suggested new technique, the Temperature Gradient Method (TGM) to measure $Q_{a}$ is based on the presence of extracorporeal arterio-venous temperature gradients, and therefore does not require the injection of an indicator or thermal bolus. In order to test this new technique in vivo measurements were performed and compared to results obtained by classic saline dilution, considered the reference technique in this field.

The aim of the present study was first to analyze the agreement between saline dilution and TGM, secondly to determine the repeatability of each separate measurement technique, and thirdly, to determine the time requirements for the new technique. 


\section{Patients and methods}

\section{Protocol}

Qa measurements were performed once by each separate measuring technique during the first hour of dialysis. Dialysate temperature was set at $35.5^{\circ} \mathrm{C}$. Temperatures were measured by the blood temperature monitor $\left(\mathrm{BTM}^{\circledR}\right.$, Fresenius Medical Care Germany, Bad Homburg). First, arterial $\left(T_{\text {art,n }}\right)$ and venous temperatures $\left(T_{\text {ven,n }}\right)$ were registered after stabilization of temperatures with lines in normal position (indicated by the subscript $\mathrm{n}$ ). Secondly, extracorporeal lines were reversed (indicated by the subscript $x$ ) and $T_{\text {art, } x}, T_{\text {ven,x }}$ and effective extra corporeal blood flow $\left(\mathrm{Q}_{\mathrm{b}, \mathrm{x}}\right)$ were registered after stabilization of BTM temperatures. Temperature stabilization after line reversal was detected by continuous temperature monitoring for a duration of up to 10 minutes. After TGM measurements, $Q_{a}$ was measured using the saline dilution technique (HD01, Transonic $^{\circledR}$, Transonic Systems Inc., Ithaca, NY). Blood pressure was measured before each access flow measurement. Measurements were done at an extracorporeal blood flow of $300 \mathrm{ml} / \mathrm{min}$ as advised by the reference technique. Each vascular access was studied twice with an interval of one week between measurements. All patients gave informed consent to participate in this study.

\section{Analysis techniques}

\section{Saline dilution}

Measuring access flow using saline dilution, a bolus of isotonic saline (indicator) is administrated into the venous bubble trap after line reversal. Two ultrasound dilution sensors are clamped onto the bloodlines, one on the arterial and one on the venous bloodline. The venous saline dilution sensor will first sense the diluted blood used as a reference value to calculate the actual recirculation $(R)$ of saline entering the arterial line.

Besides sensing dilution, the ultrasound sensors simultaneously measure blood flow in the bloodlines $\left(Q_{b}\right)$. $Q_{a}$ can now be calculated with the formula $Q_{a}=Q_{b}{ }^{*}((1-R) / R)$.

\section{Temperature Gradient Method}

When blood lines are reversed, the arterial temperature $T_{\text {art, } x}$ leaving the access is the result of the mixture of access inflow temperature and the temperature of venous line blood returning to the access (Figure 5.1). 


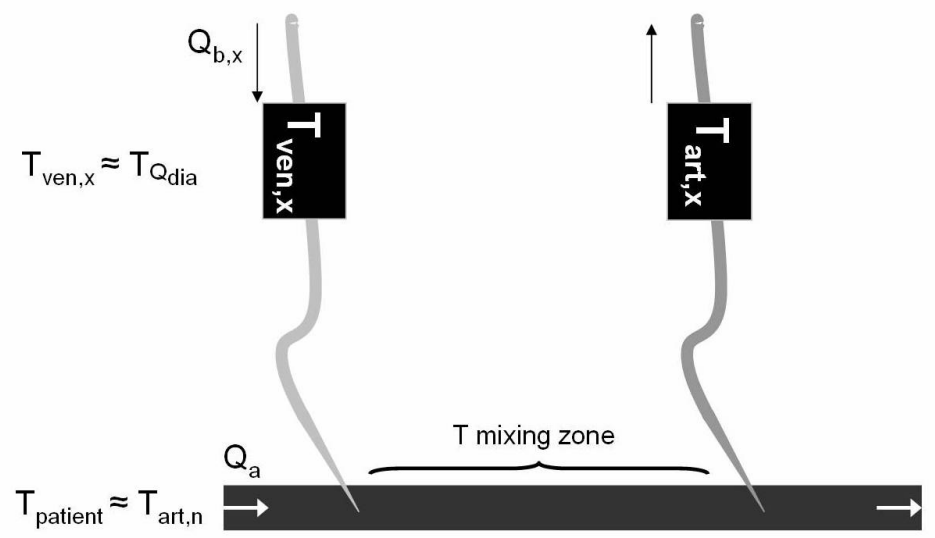

Figure 5.1 Reversed line measurement setup Temperature Gradient Method (TGM).

$Q_{a}=$ access flow, $Q_{b, x}=$ extracorporeal blood flow when lines are reversed, $T_{\text {ven, } x}=$ temperature in the venous bloodline, $T_{\text {art }, n}=$ temperature in the arterial bloodline before line reversal, $T_{\text {art }, x}=$ temperature in the arterial bloodline after line reversal, $T_{\text {Qdia }}=$ dialysate temperature, $T_{\text {patient }}=$ patient temperature. The mixture of $T_{\text {ven, } x}$ and $T_{\text {patient }}$ between the needles caused by forced recirculation when lines are switched is reflected in $T_{\text {art, } x}$.

With help of previous described variables, $Q_{a}$ can be calculated. Mathematically this relation is represented in equation 5.1 :

Equation 5.1

$$
Q_{a}=\left(Q_{b, x}-U F R\right) \frac{T_{a r t, x}-T_{v e n, x}}{T_{a r t, n}-T_{a r t, x}}
$$

The measurement of $Q_{a}$ therefore requires the measurement of arterial and venous line temperatures with correct and reversed placement of blood lines in the presence of arterio-venous temperature gradients. Since arterial and venous temperatures are continuously measured in the current BTM configuration, the measurement of $Q_{a}$ only requires to reverse the arterial and venous line and to measure the step-change in arterial line temperature. A more detailed description of the TGM is described elsewhere $^{5,6}$.

\section{Dialysis strategy}

Patients were either treated with bicarbonate hemodialysis with low flux polysulfone membranes (F8HPS; Fresenius; Bad Homburg; Germany) $(\mathrm{N}=31)$ or with on-line postdilution hemodiafiltration (HDF) with high flux membranes (APS-1050, Asahi Medical Co., Tokyo, Japan) ( $\mathrm{N}=4)$. Postdilution HDF has no effect on BTM measurement as the substitution fluid is from the same source as the dialysate. So 
changing the dialysate temperature also affects the substitution fluid temperature in the same way. Using the Transonic HD01, infusion of substitution fluid was temporarily stopped because it interferes with the venous line ultrasound signal.

Sodium concentration of the dialysate was 138 or $140 \mathrm{mmol} / \mathrm{l}$, calcium concentration was $1.5 \mathrm{mmol} / \mathrm{l}$ and temperature of the dialysate was set at $35.5^{\circ} \mathrm{C}$. Ultrapure dialysate was used.

\section{Statistical analysis}

Statistical analysis was performed using SPSS 12.01 software (SPSS ${ }^{\circledR}$ Inc., Chicago, IL, USA). Correlations between vascular access flow measured by different methods were estimated by Pearson product moment correlations. A Bland and Altman plot was used to visually assess agreement between the different methods. The repeatability of both techniques was assessed by analyzing the relative difference of weekly subsequent measurements: $\Delta X_{\text {rel }}=\sqrt{ }\left[\left(X_{2} / X_{1}-1\right)^{2}\right] 100$. Data are expressed as mean $\pm S D$. $p<0.05$ were considered significant.

\section{Results}

The study was done in 35 vascular accesses (13 forearm fistula, 9 upper arm fistula, 12 grafts, 1 upper arm graft) of 35 ESRD patients and repeated once. Therefore, 70 measurement pairs consisting of consecutive TGM and HDM were available for analysis.

\section{Agreement between both techniques}

Average $Q_{a}$ measured with the saline dilution technique was $960 \pm 594 \mathrm{ml} / \mathrm{min}$ and with the TGM $1000 \pm 588 \mathrm{ml} / \mathrm{min}(p=n s)$. Correlation between $Q_{a}$ measurements by both techniques expressed in $r^{2}$ was $0.930(r=0.964 ; p<0.05)$ (Figure 5.2). The limits of agreement for the difference between TGM and saline dilution were $2-77 \mathrm{ml} / \mathrm{min}$. A Bland-Altman plot comparing the two techniques is displayed in Figure 5.3. 


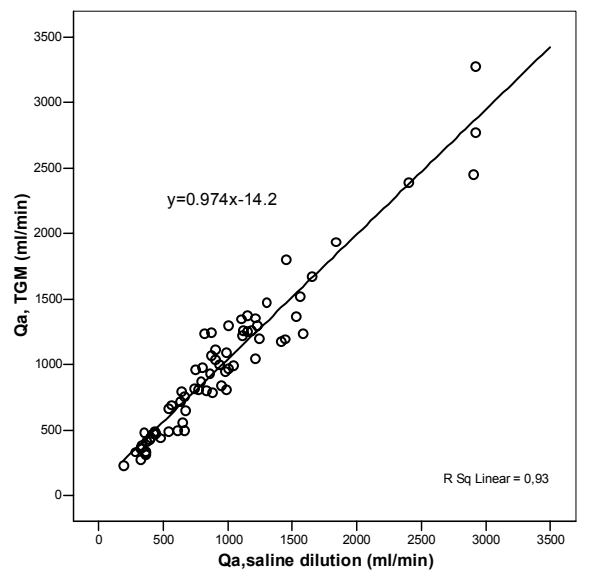

Figure 5.2 Correlation between saline dilution and TGM.

$Q_{a}=$ access flow, $T G M=$ Temperature Gradient Method

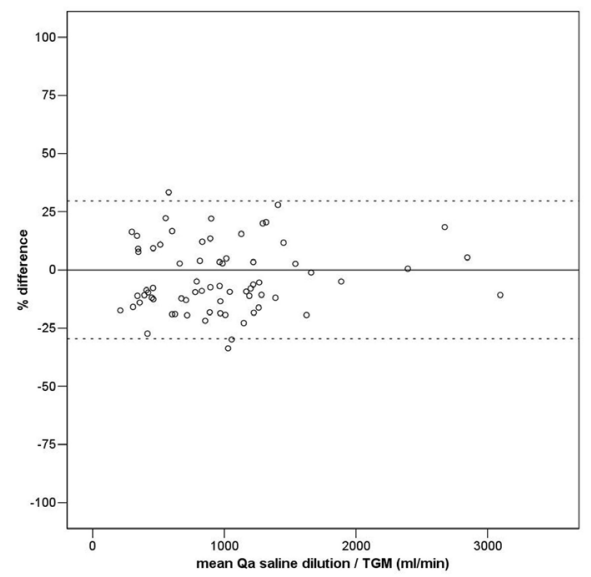

Figure 5.3 Bland-Altman saline dilution / TGM.

$Q_{a}=$ access flow, TGM=Temperature Gradient Method, dotted lines refer to two times the standard deviation of the mean relative difference.

\section{Repeatability results of each separate technique}

Repeatability of saline dilution and TGM measurements within a weekly interval, expressed as a relative difference $\left(\Delta \mathrm{X}_{\text {rel }}\right)$ was $15.4+/-14.3$ and $20.6+/-19.4 \%$, respectively $(p=n s)$. The absolute difference between TGM and saline dilution measurement results is presented in a histogram (Figure 5.4).

The correlation of subsequent measurements expressed as $r^{2}$ was $0.88(r=0.94)$ for saline dilution, and 0.85 ( $r=0.92)$ for TGM, respectively. 


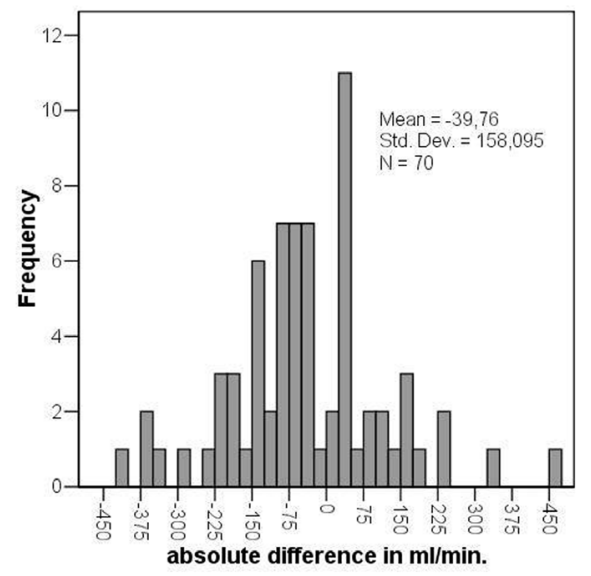

Figure 5.4 Absolute difference between consecutive TGM and saline dilution measurements.

\section{Additional results}

The mean relative difference between $\mathrm{Q}_{\mathrm{b}}$ measured by both techniques was $4.7+/-3.4 \%$ (70 measurements).

$\mathrm{T}_{\text {art, } \mathrm{x}}$ (70 registrations) stabilized within 3:00 and 9:15 minutes after having reversed the blood lines (Figure 5.5). Stabilization was achieved when temperatures remained stable (meaning the exact same temperature) for at least one minute, counting from 2.5 minutes after line reversal.

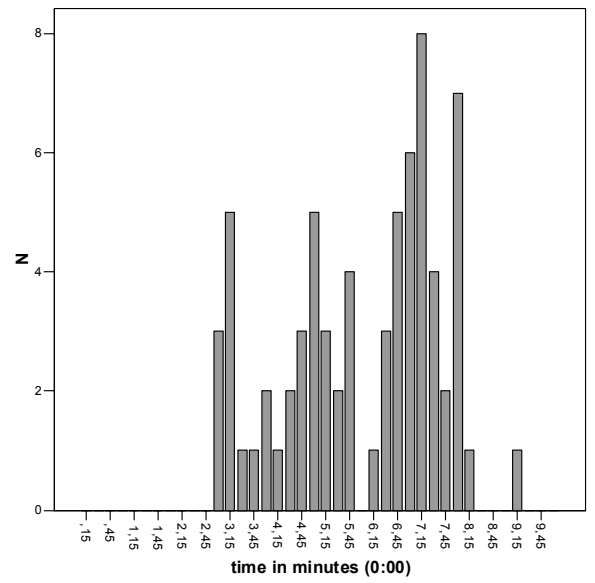

Figure 5.5 Stabilization analysis of $\mathrm{T}_{\text {art, }}$.

Distribution of time delays (in increments of 15 seconds) to reach stable arterial temperatures (exact same arterial temperature for at least one minute) after having switched the bloodlines. $\mathrm{T}_{\text {art }, \mathrm{x}}=$ temperature in the arterial bloodline after line reversal, $\mathrm{N}=$ =number of $\mathrm{T}_{\text {art }, \mathrm{x}}$ stabilization moments after line reversal (total $\mathrm{N}=70$ ). 
The average fluctuation of $T_{\text {ven, }}$ (70 registrations), registered from 2 until 10 minutes after line reversal, was $0.021+/-0.010^{\circ} \mathrm{C}$.

The average duration to measure $Q_{a}$ with saline dilution was 5.1+/-0.7 minutes, counted from the time of stopping $\mathrm{Qb}$, reversing the blood lines, doing the dilution, waiting for the result and switching lines back to normal position. The average duration to measure $Q_{a}$ with the TGM technique was $8.9+/-3.5$ minutes $(p<0.05)$, counted from the time of registering $T_{\text {art,n }}$, reversing the bloodlines, registering $T_{\text {art }, x}, T_{v e n, x}, Q_{b, x}$ after stabilization, and switching lines back to normal position.

The mean arterial pressures (MAP) at which the repeatability tests were performed for saline dilution $Q_{a}$ measurements were $84.0+/-21.2 \mathrm{mmHg}$ (week 1) and $83.4+/-17.7$ $\mathrm{mmHg}$ (week 2), respectively.

The MAP at which the repeatability tests were performed for TGM access flow measurements were $86.1+/-23.2 \mathrm{mmHg}$ (week 1) and $85.5+/-19.1 \mathrm{mmHg}$ (week 2), respectively. Within saline dilution and within TGM and between saline dilution and TGM there were no significant differences in MAP between week 1 and week 2 .

\section{Discussion}

In this study a new and abridged technique to measure access flow based on extracorporeal temperature gradients during dialysis was compared to the saline dilution technique. The comparison showed a high correlation of measurements obtained by TGM and saline dilution techniques and a high reproducibility of subsequent weekly measurements. Moreover, the TGM $Q_{a}$ measurement was quick and simple, as it is no longer required to inject an indicator (either manually or automatically).

This new technique to measure vascular access flow has several advantages compared to the thermodilution technique, reported previously. First, the TGM technique is less time consuming: $8.9+/-3.5$ minutes, whereas the thermodilution measurement takes $29+/-7$ minutes to perform one access flow measurement ${ }^{4}$. Second, the TGM does not require the injection of indicator which simplifies the measurement. Third, the correlation coefficient of subsequent measurements $(r=0.92)$ appears to be comparable or even better to the original thermodilution technique (Lopot et al. ${ }^{5} r=0.92$, Wijnen et al. ${ }^{4} r=0.89$ and Ragg et al. $\left.{ }^{6} \mathrm{r}=0.68\right)$. As opposed to the thermodilution technique ${ }^{4}$ TGM reproducibility expressed in relative difference $\left(\Delta \mathrm{X}_{\text {rel }}\right)$ did not significantly differ from the saline dilution reproducibility $(20.6+/-19.4$ and $15.4+/-14.3 \%$, respectively $(p=n s))$.

An important remark has to be made regarding reproducibility. It is difficult to assess invivo reproducibility of techniques measuring access flow because of the duration of the 
measurements and because of possible hemodynamic changes which by themselves will influence access flow ${ }^{7}$. Access flow can be assumed to follow Poiseuille's Law and to depend on access resistance, on in- and outflow pressures of the access loop, and on rheologic properties of blood. Access resistance represents the sum of serial resistances from the level of the arterial anastomosis to the venous outflow and the central venous conduit ${ }^{8}$. In a first approximation one can assume that access resistance is not actively controlled during hemodialysis and therefore remains more or less stable within the same dialysis treatment as previously shown ${ }^{9}$. A similar consideration applies to the rheologic properties of blood. Even though hematocrit increases during hemodialysis and ultrafiltration, the effect of increasing blood viscosity on access flow can be considered as negligible. Thus, the major factor causing acute changes in access blood flow is the driving pressure across the access loop which is governed by mean arterial pressure. Therefore, if mean arterial pressures are comparable among measurements, access blood flows are also likely to be comparable within the same treatment and likely to be comparable within subsequent treatments.

This study was designed to compare the TGM with the currently accepted reference technique (saline dilution). To obtain an idea of measurement quality, apart from studying the agreement between the two described techniques, weekly interval reproducibility was studied at the same mean arterial blood pressure to exclude variation caused by differences in hemodynamic conditions.

An impression of weekly Qa variation at the same mean arterial pressure can be illustrated by analyzing the reproducibility of the saline dilution technique: Depner and Krivitski. ${ }^{10}$ found a relative difference of $5.0+/-3.8 \%(\mathrm{~N}=110)$ in two measurements done within two minutes. As in the authors dialysis unit routine Qa measurements (saline dilution) are done in triplicate we were able to analyze reproducibility as well. 500 randomized subsequent measurements in a broad flow range $(290-3120 \mathrm{ml} / \mathrm{min})$ were analyzed. Saline dilution reproducibility $(6.9+/-4.8 \%)$ was comparable with the results found by Depner and Krivitski. Weekly interval reproducibility of saline dilution in this study $(15.4+/-14.3 \%)$ and in Wijnen et al. ${ }^{4}(13+/-11 \%)$ roughly differed by $8-10 \%$ compared to previously described reproducibility results $(6.9+/-4.8 \%$ and $5.0+/-3.8 \%$, authors and Depner's analysis, respectively).

The reproducibility of both measuring techniques in this study suggest that a sizable fraction of patients might have had a Qa change of more than $25 \%$ from the preceding value and in case of a $25 \%$ decline or more this would have been an indication for preemptive intervention. Out of the 35 included patients there were four patients with a relatively large $\mathrm{Qa}$ increase in week 2 compared to week 1, measured with the saline dilution technique $(47 \%$, i.e., from 1060 to $1560 \mathrm{ml} / \mathrm{min}$, in week 1 vs week 2, respectively; $43 \%$, i.e, from 860 to $1230 \mathrm{ml} / \mathrm{min}$; $55 \%$, i.e., from 420 to $660 \mathrm{ml} / \mathrm{min}$; and 
$45 \%$, i.e., from 820 to $1190 \mathrm{ml} / \mathrm{min}$, respectively). These data correlate with historic Qa results obtained by standard Qa surveillance measurements (obtained by saline dilution) that showed similar flow variations over monthly measurements. The four described patients all had native fistulas, which supports the assumption that native fistulas have a more variable flow pattern compared to grafts.

Only one patient had a Qa decline of more than 25\% (32\%). Qa in this patients' graft was recognized as low $(+/-300 \mathrm{ml} / \mathrm{min})$ and was accepted because a recently performed radiological interventions did not increase flow, besides the patient was seen with very low blood pressures (app 80/50). This patient was deliberately included for known low blood flow. Qa results for this patient by both techniques were: 333 and $280 \mathrm{ml} / \mathrm{min}$ at week 1 by TGM and saline dilution, respectively, and 230 and $190 \mathrm{ml} / \mathrm{min}$ at week 2 by TGM and saline dilution, respectively.

Apart form the described Qa decline of more than 25\%, we observed one more Qa decline in a graft obtained by TGM (31\%, from 1350 to $933 \mathrm{ml} / \mathrm{min}$, in week 1 vs week 2, respectively) which would have been the only indication for intervention in all accesses studied. Based on the saline dilution measurement (780 and $810 \mathrm{ml} / \mathrm{min}$ ) no action was taken.

We observed four increased flows (>25\%) obtained with the TGM in four AVF: $33 \%$ (from 1355 to $1799 \mathrm{ml} / \mathrm{min}$, in week 1 vs week 2, respectively), 34\% (from 2449 to 3273 $\mathrm{ml} / \mathrm{min}$ ), $32 \%$ (from 314 to $415 \mathrm{ml} / \mathrm{min}$ ) and $40 \%$ (from 929 to $1300 \mathrm{ml} / \mathrm{min}$ ).

The results of the TGM technique correlated closely with the results of the saline dilution technique $(r=0.96)$. So far, most other on-line access flow measurement techniques showed less or inferior correlation. Lopot et al. ${ }^{5}$ compared the saline dilution technique with thermodilution ( $r=0.95)$, opto-dilutional reversed lines measurement, $(r=0.70)$ and direct opto-dilutional access flow evaluation from step-changes in ultrafiltration rate, $(r=0.70)$, although Yarar et al. ${ }^{11}$ found a better correspondence to the saline dilution technique with this ultrafiltration method $(r=0.92)$. Ram et al. ${ }^{12}$ compared the saline dilution method with the glucose pump test $(r=0.91)$. Recently, another technique to measure access flow bypassing the injection of a marker was presented ${ }^{13}$. This technique is based on the measurement of effective urea clearance and on the change in urea dialysate concentrations caused by reversing the extracorporeal bloodlines. Two variants of this approach were tested and the results correlated well with saline dilution, with $r=0.92$ and $r=0.94$, respectively. However, this technique requires the presence of an on-line urea sampling device and the authors did not report the time requirements for this new test. Stabilization in dialysate concentrations is likely to be delayed in comparison to blood concentrations or temperatures because of considerable additional dead space between the access and the measuring sites. 
The accuracy of $Q_{a}$ measurements using the TGM technique importantly depends on the stability of dialysate flow and dialysate temperature. When dialysate flow is temporarily interrupted, this is reflected in changes in venous line temperature $T_{\text {ven, } x}$ which will affect the accuracy of the access flow measurement. During this study dialysate flow was constant. Fluctuations in $T_{\text {ven, } x}$ appeared to be limited to an average of $0.021+/-0.010^{\circ} \mathrm{C}$.

Figure 5.4 shows that arterial temperature $T_{\text {art, } x}$ stabilized within 10 minutes, however no clear relationship between experimental conditions such as patient temperatures or access flows and the duration to reach stable readings could be recognized.

As described in the Materials and Methods section dialysate temperature was set at $35.5^{\circ} \mathrm{C}$. This temperature was chosen to establish a significant difference between $T_{\text {art }}$ and $T_{\text {ven. }}$. When the gradient between $T_{\text {art }}$ and $T_{\text {ven }}$ narrows, the calculation of $Q_{a}$ (equation 1) can be expected to be less accurate due to the finite temperature resolution of the BTM temperature measurement. Standard dialysate settings in approximately one third of included patients include standard dialysate temperatures of $35.5^{\circ} \mathrm{C}$ to obtain haemodynamic stability during dialysis treatment. Although a low dialysate temperature may result in coldness and shivering, none of the included patients, even in patients who are normally dialysed against a higher dialysate temperature, complained of uncomfortable sensations. Measurements were performed during the first hour of dialysis and temperature settings were returned to their normal settings after the access flow measurements. Although no data are available in the literature, less than one hour of dialysate temperatures at $35.5^{\circ} \mathrm{C}$ in our study does not seem to provoke any uncomfortable sensation. Nor have we seen a significant blood pressure increase in patients with the dialysate temperature set at $35.5^{\circ} \mathrm{C}$. On the contrary, choosing a higher dialysate temperature in order to achieve a similar temperature gradient but in the opposite direction might provoke a decrease in blood pressure, while lower dialysate temperature settings are more or less a means to maintain blood pressure stability. This is the reason why we deliberately choose to create a sufficient temperature gradient through 'cold' dialysis.

The effect of low dialysate temperature on access blood flow has not been studied systematically, as far as we know. Most access flow measurements have been done (and are still done) under unknown temperature conditions. It is only with the BTM used in this study that thermal effects caused by dialysis can be adequately measured and controlled, but there are no reports on this topic. If at all, we expect an indirect effect of cool or warm dialysis on access flow caused by differences in arterial pressure, as blood flow through the vascular access is not directly controlled by vasoconstriction or vasodilatation. As mentioned before, cool dialysate will help to maintain blood pressure and may therefore help to prevent access blood flow from dropping during hemodialysis. 
But as measurements were done early in dialysis, effects of extracorporeal cooling or warming will be of minor importance at that stage of dialysis.

The use of a switch to reverse the extracorporeal blood lines integrated in some extracorporeal tubing sets (for example the Reverso ${ }^{\circledR}$, Medisystems Corporation, Seattle, USA) might further simplify the TGM measurement. When $Q_{b}$ will not be interrupted, stabilization of temperatures might occur earlier in time. Moreover, specific software, integrated in the dialysis machine, could register the temperature stabilization and based on the other gathered variables, automatically calculate Qa. In an in vitro model, Schneditz et al. ${ }^{5}$ showed that it is even possible to shorten the measuring time by analyzing the whole time course of arterial and venous line temperatures. Use of integrated software would not just simplify the measurement but would also prevent errors related to manual measurement.

In conclusion, TGM $Q_{a}$ measurements significantly correlated with the saline dilution $Q_{a}$ measurements. This new BTM technique of manually switching lines results in an accurate measure of $Q_{a}$, with a reproducibility comparable to results obtained by saline dilution, however, without the requirement to inject an indicator.

In consideration of described technical aspects and the size of this study, additional studies are required before the TGM technique to measure vascular access flow can be recommended for widespread use. 


\section{References}

1. NKF-K/DOQI. Clinical Practice Guidelines for Vascular Access: Update 2006. Am J Kidney Dis 2006;48:S176-S247.

2. Krivitski NM. Theory and validation of access flow measurement by dilution technique during hemodialysis. Kidney Int 1995;48:244-250.

3. Schneditz D, Fan Z, Kaufman A, Levin NW. Measurement of access flow during dialysis using the constant infusion approach. ASAIO J 1998;44:74-81.

4. Wijnen E, Essers S, van Meijel G, Kooman JP, Tordoir J, Leunissen KM, van der Sande FM. Comparison Between Two On-Line Reversed Line Position Hemodialysis Vascular Access Flow Measurement Techniques: Saline Dilution and Thermodilution. ASAIO J 2006;52: 410-415.

5. Schneditz D, Bachler I, van der Sande FM. Timing and reproducibility of access flow measurements using extracorporeal temperature gradients. ASAIO J 2007;53:469-473.

6. Schneditz D, van der Sande FM, Bachler I, et al. Access flow measurement by indicator dilution without indicator injection: Effect of switch location. Int J Artif Organs 2007;30: 980-986.

7. Lopot F, Nejedly B, Sulkova S, Blaha J. Comparison of different techniques of hemodialysis vascular access flow evaluation. Int J Artif Organs 2003;26:1056-1063.

8. Ragg JL, Treacy JP, Snelling P, Flack M, Anderton S. Confidence limits of arteriovenous fistula flow rate measured by the 'on-line' thermodilution technique. Nephrol Dial Transplant 2003;18:955-960.

9. Rehman SU, Pupim LB, Shyr Y, Hakim R, Ikizler TA. Intradialytic serial vascular access flow measurements. Am J Kidney Dis 1999;34:471-477.

10. van Gemert MJ, Bruyninckx CM, Baggen MJ. Shunt haemodynamics and extracorporeal dialysis: an electrical resistance network analysis. Phys Med Biol 1984;29:219-235

11. Schneditz D, Fan Z, Kaufman AM, Levin NW. Stability of access resistance during hemodialysis. Nephrol Dial Transplant 1998;13:739-744

12. Depner TA, Krivitski NM. Clinical measurement of blood flow in hemodialysis access fistulae and grafts by ultrasound dilution. ASAIO J 1995; 41:M745-M749.

13. Yarar D, Cheung AK, Sakiewica P, Lindsay RM, Paganini EP, Steuer RR, Leypoldt JK. Ultrafiltration Method for Measuring Vascular Access Flow Rates during Hemodialysis Kidney International 1999;56:1129-1135.

14. Ram SJ, Magnasco A, Jones SA, Barz A, Zsom L, Swamy S, Paulson WD. In vivo validation of glucose pump test for measurement of hemodialysis access flow Am J Kidney Dis 2003; 42:752-760.

15. Lindsay RM, Sternby J, Olde B, Persson R, Thatcher ME, Sargent K. Hemodialysis Blood Access Flow Rates Can Be Estimated Accurately from On-Line Dialysate Urea Measurements and the Knowledge of Effective Dialyzer Urea Clearance. Clin J Am Soc Nephrol 2006;1:960-964. 
Chapter 6

\section{Vascular access recirculation: setting a new detection method in the context of the overall utility of detection. Commentary}

E Wijnen, FM van der Sande, JP Kooman, KML Leunissen

Nat Clin Pract Nephrol 2007;3:252-253 
Despite recent discussion about the utility of vascular access surveillance, which has primarily focused on the effects of such surveillance on access survival ${ }^{1}$, the National Kidney Foundation's recently updated Kidney Disease Outcomes Quality Initiative (K/DOQI) guidelines for vascular access ${ }^{2}$ stress the need for timely detection and correction of stenosis in order to avoid underdialysis and to reduce the risk of thrombosis. One of the oldest approaches to vascular access surveillance is measurement of vascular access recirculation $(R)$, which detects impaired blood flow in the access and, therefore, indicates risk of thrombosis.

Magnasco and Alloatti ${ }^{3}$ compared a new method for measuring $R$ based on glucose infusion (the GIT) with the most commonly used method, which is based on saline dilution and uses either the HD01 or HD02 device (Transonic Systems Inc., Ithaca, NY). They concluded that the GIT performed well and had better sensitivity than the saline dilution method in an in vitro artificial recirculation circuit. Moreover, in vivo measurements confirmed the in vitro findings. The authors concluded that the GIT is simple, user-friendly and inexpensive, as it does not require a costly device like the HD01 or HD02 monitor.

When discussing the limitations of the study, the authors acknowledge the low number of prosthetic arteriovenous grafts (AVG) that were studied compared with the number of native arteriovenous fistulae (AVF; 12 vs 133). They conclude, however, that AVF appear to be the best model for $R$ because they remain patent until access flow is very low, when $R$ can occur. AVG, by contrast, are unlikely to remain patent at such low levels of flow. This limitation of the study is actually a limitation of $R$ measurement in general, and the K/DOQI guidelines for vascular access exclude $R$ measurement as a surveillance method for AVG for this reason. It is generally known that AVG have far lower patency rates than AVF. A well designed and structured surveillance program that combines an effective surveillance method with pre-emptive intervention is more beneficial in patients with AVG (resulting in a thrombosis rate of $<0.5 /$ patient-year compared with 0.8-1.2/patient-year at baseline) than in those with AVF (thrombosis rates of $0.1-0.2$ /patient-year and $0.2-0.4$ /patient-year, respectively) ${ }^{4}$.

Is $R$ measurement valuable in AVF? Lopot et al. ${ }^{5}$ summarized the major drawbacks of this approach. Firstly, actual $R$ is too late a finding. It appears when access flow has declined to a level comparable to normal blood pump speed settings (300-400 $\mathrm{ml} / \mathrm{min}$ ). Secondly, measurement of $R$ cannot detect a stenosis between the needles. The extracorporeal circuit creates a bypass around the stenosis, allowing it to develop unnoticed until the access becomes completely occluded. 
During the past decade, access flow evaluation has been considered the access surveillance tool of choice, followed by static venous pressure monitoring. ${ }^{2}$ If access flow measurement is used, a decline in flow will usually be identified before recirculation appears. The only extra value that $R$ measurement might add to access flow measurement arises when flow is less than blood pump speed. In this situation (as described above), absence of recirculation could point towards an intra-needle stenosis, which might be relevant to the interventional radiologist or surgeon.

In conclusion, the GIT is an easy and effective means of measuring $R$; however, the value of $R$ measurement has lessened considerably during the past decade with the development of other surveillance tools, which have higher sensitivity for timely detection of stenosis. 


\section{References}

1 Paulson WD. Access monitoring does not really improve outcomes. Blood Purif 2005;23: 50-56.

2 Vascular Access 2006 Work Group. Clinical practice guidelines for vascular access. Am J Kidney Dis 2006;48(S1):S176-S247.

3 Magnasco A, Alloatti S. Glucose infusion test (GIT) compared with the saline dilution technology in recirculation measurements. Nephrol Dial Transplant 2006;21:3180-3184.

4 Sands JJ. Vascular access monitoring improves outcomes. Blood Purif 2005;23:45-49.

5 Lopot F, Nejedlý B, Válek M. Vascular access monitoring: methods and proceduressomething to standardize? Blood Purif 2005;23:36-44. 


\section{Chapter 7}

The relation between vascular access flow and different types of vascular access with systemic hemodynamics in hemodialysis patients

E Wijnen, XH Keuter, NR Planken,

FM van der Sande, JH Tordoir, KML Leunissen, JP Kooman 


\section{Abstract}

\section{Introduction}

Access flow $(\mathrm{Qa})$ has an important effect on systemic hemodynamics in dialysis patients. A Qa: cardiac output (CO) ratio higher than 0.3 is considered a risk factor for high-output cardiac failure. However, the effect of different types of vascular access in hemodialysis patients has not yet been studied. Aim of the present study was to assess the relationship between $Q a$ and systemic hemodynamics and to compare systemic hemodynamics between patients with elbow/upperarm access with forearm access types.

\section{Methods}

$\mathrm{Qa}$, cardiac output $(\mathrm{CO})$, cardiac index $(\mathrm{Cl})$, central blood volume and peripheral vascular resistance (PVR) were studied by the saline dilution technique in 58 hemodialysis patients (18 elbow/upperarm access; 40 with forearm access types).

\section{Results}

Qa was significantly and positively related to $\mathrm{CO}$ and $\mathrm{Cl}$, and inversely to PVR. Central blood volume, Qa and presence of cardiac failure were independent determinants of $\mathrm{Cl}$. Qa and the Qa:CO ratio were significantly higher and PVR significantly lower in patients with elbow/upper arm access compared to forearm access types. When patients with cardiac failure were excluded, $\mathrm{CO}$ and $\mathrm{Cl}$ were also significantly higher in patients with elbow/upper arm access types. $11 \%$ of patients with elbow/upperarm fistula had a Qa:CO ratio above 0.3 .

\section{Conclusion}

Qa is strongly related to systemic hemodynamics in dialysis patients. In patients without cardiac failure, $\mathrm{CO}$ and $\mathrm{Cl}$ are significantly higher in patients with elbow/upperarm access compared to patients with forearm access types. However, only a small percentage of patients with elbow/ upperarm fistulae appeared to be in the risk zone for development of high-output cardiac failure. 


\section{Introduction}

Recent guidelines have advocated the construction of vascular access with native blood vessels instead of the use of artificial materials such as polytetrafluoroethylene (PTFE), because of the reduced graft survival and the increased incidence of stenotic and thrombotic complications associated with the latter approach. However, in various patients, construction of Cimino-Brescia fistula may fail because of bad quality of the forearm vasculature. In those patients, construction of elbow (brachial-cephalic) or transposed brachial-basilic fistula is often a good option associated with long term fistula patency ${ }^{1}$.

Due to their generally higher access flow (Qa), elbow/upper arm fistula may have different hemodynamic effects on the heart compared to forearm fistula and grafts, leading to a hyperdynamic state ${ }^{2}$. Several case reports showed high-output cardiac failure in patients with high-flow fistula and improvement of cardiac function after closure of the fistula $a^{2-6}$. Moreover, in previous studies, a significant relation between cardiac output (CO) and Qa was observed ${ }^{7-9}$.

To the best of our knowledge, the hemodynamic effects of forearm versus elbow/upper arm access types have not yet been investigated in larger patient groups. Moreover, with the introduction of the saline dilution technique, it has become possible to assess systemic hemodynamics during dialysis in an easy way ${ }^{10}$.

Aim of the present study was firstly to assess the relation between cardiac function and access flow, and to compare the hemodynamic effects of elbow/upperarm fistula with those of forearm access types.

\section{Patients and Methods}

\section{Patients}

After informed consent, 58 patients in our dialysis center were included in this study. Our hemodialysis population consists of 68 patients. Nine patients were dialyzed with central venous catheters and were thus not eligible for study. One patient has a thoracic loop and was also not included in the analysis. Forty patients had a forearm access, of whom 21 had radiocephalic fistulae and 19 PTFE grafts. Eighteen patients had an elbow/upper arm access types, of whom 9 had brachiocephalic and 9 transposed brachial-basilic fistulae. Mean age, weight, and height did not differ between patients with forearm and upper arm/elbow access types (Table 7.1), nor did the presence of diabetes mellitus. However, the prevalence of (pre-existent) cardiac failure (NYHA class III or higher) was higher in patients with elbow/upper arm access. In patients with 
cardiac failure, age was significantly higher compared to patients without cardiac failure $(80.0 \pm 9.5$ versus $67.5 \pm 11.6$ years; $p<0.001)$, whereas time on dialysis was shorter in patients with cardiac failure $(1.2 \pm 0.4$ years versus $3.9 \pm 2.6$ years; $p<0.001)$.

Table 7.1 Patient characteristics.

\begin{tabular}{lccc}
\hline & Forearm access & Elbow/upper arm access & $\mathrm{p}$ \\
\hline $\mathrm{N}$ & 40 & 18 & $\mathrm{~ns}$ \\
Age & $71 \pm 11$ & $67 \pm 14$ & $\mathrm{~ns}$ \\
Pre-dialytic systolic BP & $139 \pm 28$ & $129 \pm 27$ & $\mathrm{~ns}$ \\
Height (cm) & $168 \pm 9$ & $170 \pm 7$ & $\mathrm{~ns}$ \\
Weight $(\mathrm{kg})$ & $67 \pm 12$ & $67 \pm 13$ & $\mathrm{~ns}$ \\
Diabetes mellitus & $6(15 \%)$ & $2(11 \%)$ & $\mathrm{ns}$ \\
Cardiac failure & $3(8 \%)$ & $6(33 \%)$ & $\mathrm{p}<0.05$ \\
Time on dialysis (years) & $3.7 \pm 2.7$ & $2.9 \pm 2.6$ & $\mathrm{~ns}$ \\
\hline
\end{tabular}

Values expressed as mean \pm SD.

\section{Dialysis strategy}

Patients were treated with bicarbonate hemodialysis with low flux polysulfone membranes (F8HPS; Fresenius ${ }^{\circledR}$; Bad Homburg or Polyflux 8L; Gambro ${ }^{\circledR}$; Lund; Sweden). Fresenius $4008 \mathrm{H}^{\circledR}$ dialysis modules (Bad Homburg; Germany) were used. Sodium concentration of the dialysate was 138 or $140 \mathrm{mmol} / \mathrm{l}$, calcium concentration was $1.5 \mathrm{mmol} / \mathrm{l}$ and temperature of the dialysate was $35.5,36$ or $36.5^{\circ} \mathrm{C}$. Ultrapure dialysate was used, achieved by double reverse osmosis, electric deionisation, ozon sanatisatiion and filtration through Diasafe ${ }^{\circledR}$ (Fresenius Bad Homburg; Germany) or U8000 ${ }^{\circledR}$ (Gambro; Lund: Sweden) membranes.

\section{Study protocol}

Measurements were performed on a midweek dialysis. Immediately after the start of dialysis, cardiac function was assessed by the saline dilution method (Transonic $^{\circledR}$; Ithaca; USA). Hereafter, access flow was assessed, also by the saline dilution technique.

\section{Access flow measurements and assessment of systemic hemodynamic parameters by the saline dilution technique}

Qa was assessed as described previously ${ }^{12}$ and expressed as the mean of three measurements.

$\mathrm{CO}$, cardiac index $(\mathrm{Cl})$, central blood volume and peripheral vascular resistance (PVR) were assessed by the saline dilution technique (Transonic HD 01®; Transonic Systems; Ithaca NY; USA) as described in detail elsewhere ${ }^{10,13}$. In short: a heated $\left(37^{\circ} \mathrm{C}\right)$ bolus of 
$30 \mathrm{ml} \mathrm{NaCl} 0.9 \%$ (indicator) is injected into the venous line with the blood pump speed set at $200 \mathrm{ml} / \mathrm{min}$, and the change in velocity of ultrasound waves produced by the returning dilution curve $(S)$ is detected by a probe attached to the arterial line. By comparing the dilution curve with a calibration curve $\left(S_{c a l}\right)$, produced by injecting $10 \mathrm{ml}$ of isotonic saline in the venous bubble trap, $\mathrm{CO}$ is calculated by the formula: 3 * blood flow * $\left(\mathrm{S} / \mathrm{S}_{\text {cal }}\right)$. Central blood volume (CBV), which is considered to be the blood in the heart, great vessels (pulmonary artery and veins and ascending aorta) and the lung capillaries, is calculated by multiplication of $\mathrm{CO}$ with the mean transit time of the indicator, corrected for travel time in the arterial and venous blood line. Peripheral vascular resistance (PVR) was calculated by dividing mean arterial pressure, assessed by an oscillometric method (Omron M4-I ${ }^{\circledR}$; Omron Healthcare; West Sussex; UK) by CO. PVR was also corrected for body surface area (PVRI=peripheral vascular resistance index).

Coefficient of variation of $\mathrm{CO}$ between subsequent measurements, obtained in 12 patients, was $8.3 \%{ }^{10}$. Coefficient of variation for CO performed at the start of two dialysis sessions, separated by a one-week period, was $17.6 \%$.

\section{Statistical analysis}

The relation between access flow and cardiac function was assessed by Pearson's $r$. The relation between $\mathrm{Qa}$ and $\mathrm{Cl}$ was also studied using multiregression analysis (enter method), with presence of (pre-existent) cardiac failure, age, sex, systolic blood pressure, Qa, diabetes mellitus and central blood volume index (central blood volume indexed for body weight) as independent variables. Differences between patients with elbow/upperarm access and those with forearm access was assessed by the unpaired Student t-test (SPSS 12.0). A p-value below 0.05 was considered significant.

\section{Results}

\section{Relation between Qa and systemic hemodynamics}

Qa, measured directly after the start of hemodialysis, was significantly different between patients with forearm access and elbow/upper arm access types (Table 7.2). 
Table 7.2 Differences in systemic hemodynamic between patients with forearm and elbow/upperarm access types.

\begin{tabular}{lccc}
\hline & Forearm & Elbow/upper arm & $\mathrm{p}$ \\
\hline $\mathrm{N}$ & 40 & 18 & \\
Systolic BP $(\mathrm{mmHg})$ & $139 \pm 28$ & $129 \pm 27$ & $\mathrm{~ns}$ \\
Diastolic BP $(\mathrm{mmHg})$ & $70 \pm 13$ & $66 \pm 19$ & $\mathrm{~ns}$ \\
$\mathrm{PVR}(\mathrm{mmHg} / \mathrm{min} / \mathrm{l})$ & $15.4 \pm 4.4$ & $13.0 \pm 2.0$ & $\mathrm{p}<0.05$ \\
$\mathrm{PVRI}\left(\mathrm{mmHH} / \mathrm{min} / / \mathrm{m}^{2}\right)$ & $27.0 \pm 7.5$ & $23.0 \pm 5.0$ & $\mathrm{p}<0.05$ \\
Qa $(1 / \mathrm{min})$ & $878 \pm 411$ & $1350 \pm 560$ & $\mathrm{p}<0.001$ \\
$\mathrm{CO}(1 / \mathrm{min})$ & $6.4 \pm 1.9$ & $6.9 \pm 2.1$ & $\mathrm{~ns}$ \\
$\mathrm{Cl}\left(1 / \mathrm{min} / \mathrm{m}^{2}\right)$ & $3.6 \pm 1.0$ & $3.9 \pm 1.0$ & $\mathrm{~ns}$ \\
$\mathrm{CBV}(\mathrm{I})$ & $1.52 \pm 0.53$ & $1.48 \pm 0.67$ & $\mathrm{~ns}$ \\
CBVI $(1 / \mathrm{kg})$ & $23.7 \pm 7.5$ & $22.7 \pm 11.0$ & $\mathrm{~ns}$ \\
Qa:CO $(\%)$ & $14.0 \pm 6.0$ & $20.2 \pm 7.6$ & $\mathrm{p}<0.01$ \\
CO $(1 / \mathrm{min})^{\mathrm{a}}$ & $6.5 \pm 2.0$ & $7.7 \pm 1.9$ & $\mathrm{p}=0.05$ \\
Cl $\left(/ / \mathrm{min} / \mathrm{m}^{2}\right)^{\mathrm{a}}$ & $3.6 \pm 1.0$ & $4.3 \pm 1.0$ & $\mathrm{p}<0.05$ \\
\hline
\end{tabular}

Values expressed as mean $\pm \mathrm{SD}$; $\mathrm{BP}=$ blood pressure; $\mathrm{PVR}=$ peripheral resistance; $\mathrm{PVRI}=$ peripheral resistance index; $\mathrm{Q} a=$ access flow; $\mathrm{CO}=$ cardiac output; $\mathrm{Cl}=$ cardiac index; $\mathrm{CBV}=$ central blood volume; $\mathrm{CBVI}=$ central blood volume index; ${ }^{\text {a }}$ patients with cardiac failure excluded.

Of the patients with elbow/upper arm access types, Qa was not different between patients with brachio-cephalic $(1245 \pm 539 \mathrm{ml} / \mathrm{min})$ or transposed brachial-basilic fistulae $(1454 \pm 539 \mathrm{ml} / \mathrm{min})$. Of the patients with forearm access types, Qa was also not different between patients with radiocephalic fistulae $(935 \pm 415 \mathrm{ml} / \mathrm{min})$ or PTFE grafts $(814 \pm 408 \mathrm{ml} / \mathrm{min})$.

Two patients (11\%) with elbow/upper arm access and none of the patients with forearm had a Qa:CO ratio above $30 \%$ (highest value $32 \%$ ).

Pooling all patients, Qa was significantly related to $\mathrm{CO}(r=0.53 ; p<0.001), \mathrm{Cl}(r=0.56$; $p<0.001)$ (Figure 7.1), stroke volume $(r=0.43 ; p<0.01)$, peripheral vascular resistance and resistance index $(r=-0.26$ and $r=-0.26 ; p<0.05)$, systolic and diastolic blood pressure $(r=0.36$ and $r=0.43 ; p<0.01)$. With multiregression analysis (strength of model: $r^{2}=0.63 ; p<0.001$ ), central blood volume (indexed for body weight) ( $B=0.40 ; t=4.4$; $p<0.001)$, age $(B=-0.36 ; t=-3.5 ; p=0.001)$, and $Q a(B=0.48 ; t=4.8 ; p=0.001)$ were independently related to $\mathrm{Cl}$, whereas after exclusion of age from the model, presence of pre-existent cardiac failure became a significant predictor $(B=-0.30 ; t=-2.8 ; p<0.01)$. 


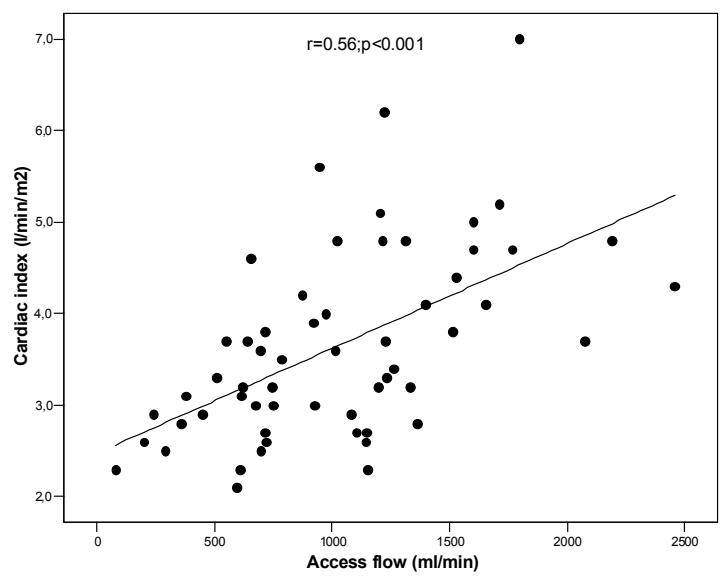

Figure 7.1 Relation between cardiac index and access flow.

PVR and PVRI were significantly lower in patients with elbow/upper arm access compared to patients with forearm access, whereas $\mathrm{Qa}$ and the Qa:CO ratio were significantly higher (Table 7.2). $\mathrm{CO}$ and $\mathrm{Cl}$, in the overall group, were not significantly different between patients with forearm and elbow/upper arm access types. However, when patients with cardiac failure were excluded, $\mathrm{Cl}$ was significantly higher in patients with elbow/upper arm access (Table 7.2) (Figure 7.2).

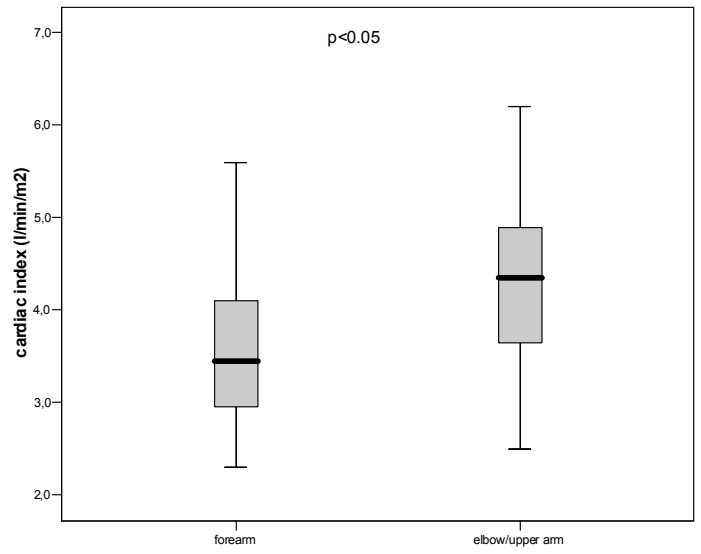

Figure 7.2 Difference in cardiac index between patients with forearm access and elbow/upper arm access in patients without cardiac failure.

Box indicates $25^{\text {th }}$ and $75^{\text {th }}$ percentiles (thick line is median value). Capped bars indicate minimum and maximum value (excluding outliers). 


\section{Discussion}

This study showed a significant relation between Qa and systemic hemodynamics, and significant differences in systemic hemodynamics between patients with elbow/upper arm and forearm access. Qa was significantly and positively related to $\mathrm{CO}$ and $\mathrm{Cl}$, and inversely to PVR. Multiregression analysis showed that CBV, an index of systemic filling, presence of cardiac failure, and $\mathrm{Qa}$ were important determinants of $\mathrm{Cl}$. The strong relation between $\mathrm{Qa}$ and $\mathrm{CO} / \mathrm{Cl}$ is in agreement with previous studies on this subject $^{7-9}$. Of course, systemic hemodynamics per se may also influence $\mathrm{Q} a$, as also shown by the relation between $\mathrm{Qa}$ and systemic blood pressure in the present study. However, this would not explain the higher $\mathrm{CO}$ in patients with elbow/upper arm fistula, as described below, despite comparable blood pressure values.

As expected, Qa was significantly higher in patients with elbow/upper arm fistula. Whereas in the overall group, $\mathrm{CO}$ or $\mathrm{Cl}$ were not significantly higher in patients with elbow/upper arm access compared to patients with forearm access types, this is probably due to the presence of confounding variables, such as pre-existent cardiac failure. The prevalence of pre-existent cardiac failure was higher in patients with elbow/upper arm access, which is likely due to the impaired quality of blood vessels in these patients, which necessitated the construction of other access types than standard radiocephalic fistula. Indeed, when patients with systemic cardiac failure were excluded from the analysis, $\mathrm{CO}$ and $\mathrm{Cl}$ were significantly higher in patients with elbow/upper arm fistula.

The parameter which was most clearly different between patients with forearm and upperarm fistula was the Qa:CO ratio, a parameter introduced by Pandeya and Lindsay $^{7}$. As mentioned previously, it has been suggested that a ratio of Qa:CO ratio above 0.3 is a risk factor for high output cardiac failure ${ }^{5}$. In our study in which patients with pre-existent cardiac failure were also included, only $11 \%$ of patients with elbow/upperarm fistula and none of the patients with forearm access had a $\mathrm{Qa} / \mathrm{CO}$ ratio above 0.3 , whereas the highest measured $\mathrm{Qa} / \mathrm{CO}$ ratio was 0.32 .

A drawback of the study is the cross-sectional design with measurements obtained during a single dialysis session, and the absence of echocardiographic data. Longitudinal studies with echocardiographic measurements are needed to assess the influence of Qa and different access types on cardiac structure. Moreover, radiocephalic fistula and PTFE grafts were not analyzed separately, nor were brachiocephalic and transposed brachial-basilic fistula. However, no difference in Qa was observed between the different forearm access types, nor between brachiocephalic and transposed brachial-basilic fistulae.

Lastly, although only a small percentage of the patients with upperarm/elbow fistulae appeared to be in the risk zone for development of high-output cardiac failure, it should 
be acknowledged that the proposed Qa:CO ratio of $0.3^{5}$ has not yet been validated in prospective trials.

\section{Conclusion}

Qa is strongly related to systemic hemodynamics in dialysis patients. In patients without cardiac failure, $\mathrm{CO}$ and $\mathrm{Cl}$ are significantly higher in patients with elbow/upper arm access compared to patients with forearm access. However, only a small percentage of patients with elbow/upperarm fistulae appeared to be in the risk zone for development of high-output cardiac failure. However, longitudinal studies are needed to assess the influence of different access types on structural cardiac changes. 


\section{References}

1. III. NKF-K/DOQI Clinical Practice Guidelines for Vascular Access: update 2000. Am J Kidney Dis 2001;37(S1):S137-181.

2. Murray BM, Rajczak S, Herman A, Leary D. Effect of surgical banding of a high-flow fistula on access flow and cardiac output: intraoperative and long-term measurements. Am J Kidney Dis 2004;44:1090-1096.

3. Dikow R, Schwenger V, Zeier M, Ritz E. Do AV fistulas contribute to cardiac mortality in hemodialysis patients? Semin Dial 2002;15:14-17.

4. Engelberts I, Tordoir JH, Boon ES, Schreij G.High-output cardiac failure due to excessive shunting in a hemodialysis access fistula: an easily overlooked diagnosis. Am J Nephrol 1995;15:323-326.

5. MacRae JM, Pandeya S, Humen DP, Krivitski N, Lindsay RM. Arteriovenous fistulaassociated high-output cardiac failure: a review of mechanisms. Am J Kidney Dis 2004; 43:e17-22.

6. Anderson CB, Codd JR, Graff RA, Groce MA, Harter HR, Newton WT. Cardiac failure and upper extremity arteriovenous dialysis fistulas. Case reports and a review of the literature. Arch Intern Med 1976;136:292-297.

7. Pandeya S, Lindsay RM. The relationship between cardiac output and access flow during hemodialysis. ASAIO J 1999;45:135-138.

8. Besarab A, Lubkowski T, Vu A, Aslam A, Frinak S. Effects of systemic hemodynamics on flow within vascular accesses used for hemodialysis. ASAIO J 2001;47:501-506.

9. Polkinghorne KR, Atkins RC, Kerr PG. Determinants of native arteriovenous fistula blood flow. Nephrology (Carlton) 2004;9:205-211.

10. Beerenhout C, Dejagere T, van der Sande FM, Bekers O, Leunissen KM, Kooman JP. Haemodynamics and electrolyte balance: a comparison between on-line pre-dilution haemofiltration and haemodialysis. Nephrol Dial Transplant 2004;19:2354-2359.

11. Agharazii $M$, Clouatre $Y$, Nolin $L$, Leblanc $M$. Variation of intra-access flow early and late into hemodialysis. ASAIO J 2000;46:452-455.

12. Krivitski NM. Theory and validation of access flow measurement by dilution technique during hemodialysis. Kidney Int 1995;48:244-250.

13. Krivitski NM, Depner TA.Cardiac output and central blood volume during hemodialysis: methodology. Adv Ren Replace Ther 1999;6:225-232. 
Chapter 8

General discussion 



\section{General discussion}

Vascular access thrombosis is a frequent complication of haemodialysis (HD) vascular access. Thrombosis is usually the result of progressive stenosis, due to intima hyperplasia of the vessel wall. Access dysfunction, endangers the quality of the HD treatment and leads to morbidity and even mortality ${ }^{1,2}$.

Hypothetically, timely stenosis detection combined with pre-emptive stenosis repair could prevent access dysfunction. The introduction of routine online access flow measurement $^{3}$ has enabled timely identification of increased thrombosis risk and provided a means for follow-up evaluation ${ }^{4,5}$.

The logic behind access flow (Qa) evaluation is that a significant stenosis increases total access circuit resistance and thereby decreasing $\mathrm{Qa}$. It is the preferred vascular access surveillance tool added to physical examination ${ }^{6,7}$. In comparison to indirect stenosis assessment tools, Qa evaluation has the benefit to detect significant stenosis and access malfunction before recirculation occurs and is independent of stenosis location, where pressure monitoring is.

Angiography combined with endovascular treatment may prevent access occlusion ${ }^{6,7}$.

In chapter two we retrospectively compared two time periods: The 'quality improvement period' (QIP) during which Qa surveillance was applied and the 'reference period' (RP) during which non-standardised clinical monitoring was applied. The comparison was focussed on thrombosis incidence, access survival and costs.

Though the incidence of access failure was similar in both RP and QIP, arteriovenous graft (AVG) thrombosis reduction led to a significant cost reduction. A recent controlled cohort study showed a significant cost reduction as well for arteriovenous fistulae (AVF), despite a significant increase in (costly) interventions ${ }^{8}$. Given the fact that 20 to $25 \%$ of all hospital admissions in HD patients is accounted for vascular access malfunction ${ }^{9,10}$, together with the worldwide increase of HD patients ${ }^{11,12}$, the economic impact of online Qa surveillance is an important outcome parameter, which may lead to healthcare cost reduction.

The results described in chapter three and two recent meta-analyses, that included studies using Doppler ultrasound as well ${ }^{13,14}$, showed no convincing proven benefit of Qa surveillance for AVG but Qa surveillance tended to be beneficial towards access thrombosis in arteriovenous fistulae (AVF). These meta-analyses suggest that the overall quality of the included studies was poor, that not all studies reported clinically relevant outcomes, and finally that the available studies had inadequate statistical power. Given the problems in maintaining functional vascular access there is desperate need for well-designed and statistical sound studies. 
The demands of a randomized clinical trial (RCT) and what should be statistical adequate are unambiguous. Before the start of any trial the application, logistics and organization of Qa surveillance and pre-emptive intervention need to be implemented adequately guided by most recent insights and guidelines. Reported studies ${ }^{15-26}$ lack a detailed description of the Qa monitoring program. It is reasonable to assume that poor implementation of a surveillance program may have major influence towards the definite outcome (thrombosis / failure). This might explain the different outcomes of (nonrandomized) trials performed in vascular access centres (described in chapter two).

So rightfully the RCTs included for review in chapter three and by Tonelli et al. ${ }^{13}$ and Casey et al. ${ }^{14}$ have been criticized for their variable quality. Though it seems unlikely that these few RCTs would not detect any difference if in fact the difference was truly of the magnitude reported in the observational trials. The retrospective nature of our study described in chapter two may have lead to unintended bias. In the enthusiasm to incorporate new technology in clinical practice, the access team was reeducated regarding access care and in the process of learning about $Q$ a surveillance, their diligence in handling and monitoring all aspects of access care were reinforced. Greater communication with radiologists and surgeons occurs when poor $\mathrm{Qa}$ prompts investigation and/or intervention. The institution of a $\mathrm{Qa}$ surveillance program emphasizes the importance of vascular access. This unconscious message is acknowledged by patients who respond by being more careful of the access. These learning and transferred behaviors are confounders that are impossible to measure but likely to contribute to the differences seen between the results described in chapter two and three as well.

Concluding, available evidence makes it difficult for any single dialysis unit to choose for Qa surveillance. Despite existing guidelines, even in a single country there is much diversity in the application of access surveillance ${ }^{27}$. A uniform approach in $\mathrm{Qa}$ surveillance combined with a solid database is the key to quality evaluation and improvement: Seldom dialysis units even report their number of occlusions. Not only available trials should per se be a guideline, own results need to be re-evaluated every time period and should serve as a continuing quality catalyst.

Of course every dialysis unit depends on the availability of all parties and structures involved in Qa surveillance: Timely access to the radiology department for pre-emptive intervention for example is mandatory. The same accounts for vascular access surgeons. It is reasonable to suggest that most outpatient HD centers may not have timely access to radiology and vascular surgery compared to in hospital dialysis centers. Organization of the vascular access intervention suite should be set up with incorporated slots and trained interventionalists. 
Vascular access resistance is determined by length and diameter of the vessels used for access creation. White et al. ${ }^{28}$ showed that diameters of the inflow artery and outflow vein vary widely in patients, and that these diameters control the relation between $\mathrm{Qa}$ and stenosis: Patients generally have smaller arteries than veins, so the feeding artery dominates Qa. In patients with artery/vein diameter ratios $<0.5$ (narrower arteries) they predicted that the intra access or outflow stenosis-induced reduction in $\mathrm{Qa}$ is delayed until critical stenosis (60 to $80 \%$ ) is reached. Assuming stenosis progresses at a constant rate, the delay and then suddenly sharp decline in Qa helps to explain why monthly online Qa measurements may often fail to warn of thrombosis.

With the use of novel techniques the frequency of measurements can be increased whereas the conventional single measurement set-up makes it logistically impossible to measure numerous patients simultaneously. A technique integrated in the dialysis machine has the potential to increase measurement frequency (possibly even every single dialysis session). A promising online and integrated technique, the thermodiltion technique, was first described by Schneditz et al. ${ }^{29}$ and compared to the reference technique (saline dilution) by Lopot et al. ${ }^{30}$. The results of both techniques showed good agreement, but repeatability was not properly assessed.

In chapter four the results of measurement repeatability of both techniques were assessed. We found a significant difference between repeatability results of the thermodilution technique and the saline dilution technique, in favour of the saline dilution technique. The large variation in subsequent measurements makes the thermodilution unsuitable for daily practice. It could lead to unnecessary interventions or failure to detect significant access flow decline. The technique described in chapter five (temperature gradient method (TGM)), showed similar repeatability results as compared to the reference technique ${ }^{3}$. This technique might be promising in near future, but prior to implementation integrated software has to be developed to further simplify the measurement and, even more important, to prevent errors related to manual measurement. When on line stenosis detection becomes available, it should be followed by timely intervention. In most studies the time period from positive Qa measurement to actual intervention is seldom mentioned. When access intervention is delayed ${ }^{15,18}$ access thrombosis after a positive Qa measurement may occur.

Van der Linden et al. ${ }^{31}$ proved that $\mathrm{Q} a$ before percutaneous transluminal angioplasty (PTA) and the post PTA increase in Qa were correlated with long-term outcomes, whereas angiographic results (percentage of diameter reduction) were not. So the true effectiveness of an angioplasty procedure, the improvement in $\mathrm{Qa}$, is not known until follow-up measurements are performed during HD treatment. The immediate measurement of intragraft blood flow during the angioplasty procedure would be a way to improve its functional success ${ }^{32}$. 
Of course, and perhaps most important, suggesting the flow limiting stenosis is detected, its' endovascular treatment effect is crucial in preventing thrombosis. Vascular injury arising from the angioplasty procedure may result in accelerated neointimal hyperplasia and contributes to restenosis. As a result, the time to restenosis after angioplasty may be significantly shorter than the time to initial stenosis ${ }^{33}$.

AVFs are recognised being superior due to the low number of complications and revisions and long overall survival ${ }^{34}$. International guidelines ${ }^{2,3}$ recommend HD access placement in the following order: a radiocephalic AVF, a brachiocephalic AVF, a transposed brachiobasilic AVF, a forearm graft, and an upper arm graft. There is an increasing number of patients with diabetes, peripheral vascular disease, and older age, in which it is difficult to create a functional radiocephalic AVF. In these patients upper arm brachiocephalic and brachiobasilic fistulae instead of AVG may be created, which is favourable as these autogenous upper arm fistulas have patency rates comparable to radiocephalic $\mathrm{AVF}^{35}$. However, an upper arm AVF has a higher risk to develop distal hypoperfusion $^{36,37}$ or heart failure.

The creation of an upper arm fistula usually leads to high and even excessive Qa due to a low inflow and venous outflow resistance compared to a forearm fistula. An overall low access circuit resistance may result in steal syndrome and limb ischemia. A high Qa combined with clinical symptoms of ischemia (cold hand, pain, sensitivity disorders, differences in left/right hand colour) need immediate evaluation ${ }^{38}$. On the other hand, when a low or normal Qa combined with similar clinical symptoms is observed, arterial inflow stenosis should be suspected.

A high $\mathrm{Qa}$ is defined as $\geq 1500 \mathrm{ml} / \mathrm{min}$ and may have significant impact on cardiac function. This cut-off value seems to be valuable as the findings described in chapter seven, indicate that most patients with a $\mathrm{Qa}$ above $1500 \mathrm{ml} / \mathrm{min}$ had Cardiac Index (Cl) values above the threshold value of $>4 \mathrm{I} / \mathrm{min} / \mathrm{m}^{2}$. Basile et al. concluded that the predictive power of $\mathrm{Q}$ a for high-output cardiac failure occurrs at a $\mathrm{Qa}$ cut-off value $>2.0$ $\mathrm{I} / \mathrm{min}^{39}$. Several case reports have been published on the devastating impact of high flow on cardiac function ${ }^{40-43}$.

As age and co-morbidities are no longer initial obstacles for the start of renal replacement therapy more end-stage renal disease patients with preexistent heart failure start with HD treatment. A radiocephalic fistula in this category of patients is mostly no option because of unsuitable veins and arteries. Second choice upper arm fistula should be performed after consultation with a cardiologist.

In those patients with created upper arm AVF and pre-existent heart failure it would be wise to apply the suggested access flow / cardiac output (Qa/CO) ratio limit of $30 \%{ }^{44}$ in stead of absolute flow solely. When poor $\mathrm{CO}$ is present prior to access creation, an apparently normal Qa of $800 \mathrm{ml} / \mathrm{min}$ might in fact be relatively high. When the $\mathrm{Qa} / \mathrm{CO}$ 
ratio exceeds, it is suggested that these patients should undergo biannual echocardiographic assessment. If the patients with elevated $\mathrm{Qa} / \mathrm{CO}$ ratios have increased left ventricular cavity volume and $\mathrm{CO}$, then fistula flow reduction should strongly be considered.

\section{Future perspectives}

Vascular access related complications place a large burden on healthcare facilities, manpower and on costs. The most problems that appear after AVF access creation are hemodynamic problems caused by the unnatural high flow conditions.

It is not surprisingly that knowing the exact amount of flow and its' deviations over time, future problems might be anticipated.

Considering the problems involved in maintaining patent vascular access a definite answer on the effect of Qa surveillance necessitates future large-scale studies with adequate study design. Important points of attention in future trials besides size and design need to be taken into account.

As discussed in this thesis novel and accurate techniques incorporated in the dialysis machine might increase measurement frequency and in consequence might timely detect rapidly progressive stenoses.

Deployment of stents at the stenotic site, by providing a rigid scaffold, may prolong access patency after angioplasty ${ }^{45,46}$. The use of drug-eluting stents or wraps ${ }^{47}$ can also be employed in vascular accesses and may have a significant impact on intima hyperplasia. Future interventional research should focus on interventions that prevent neointimal hyperplasia, and thereby limit the pathogenesis of access stenosis.

The current knowledge in view of the expected increase of upper arm AVF creation and future studies will hopefully result in guidelines with emphasis on timely detection, to prevent peripheral or central hemodynamic disturbances of apparently well functioning accesses. Qa measurement is currently mainly used for thrombosis detection. However, $\mathrm{Qa}$ is also a relevant hemodynamic parameter, providing an important additional means for timely clinical judgement of distal ischemia or cardiac decompensation. 


\section{Conclusions of this thesis}

1. A quality improvement program based on periodically access flow measurement reduced the number of vascular access failures due to thrombotic events and also significantly reduced health care costs in patients with AVG, but not in patients with AVF. The quality improvement program had no effect on access survival.

2. Until now, there is no conclusive evidence from the literature that online access flow evaluation has a significant effect on the rate of access thrombosis.

3. The thermodiluton technique to online measure access flow shows good agreement compared to the saline dilution technique, however its reproducibility is inferior compared to the saline dilution technique.

The Temperature Gradient Method to measure on line access flow shows good agreement and has similar reproducibility as the saline dilution technique.

4. Access flow is strongly related to systemic hemodynamics in dialysis patients. In patients without cardiac failure, cardiac output and cardiac index are significantly higher in patients with elbow/upper arm access compared to patients with forearm access. 


\section{References}

1. Ifudu O, Mayers JD, Cohen LS, Paul H, Brezsnyak WF, Avram MM, Herman Al, Friedman EA: Correlates of vascular access and nonvascular access-related hospitalizations in hemodialysis patients. Am J Nephrol 1996;16:118-123.

2. Bay $\mathrm{WH}$, Van Cleef $\mathrm{S}$, Owens $\mathrm{M}$. The hemodialysis access: preferences and concerns of patients, dialysis nurses and technicians, and physicians. Am J Nephrol 1998; 18: 379-383

3. Krivitski NM: Theory and validation of access flow measurement by dilution technique during haemodialysis. Kidney Int 1995;48:244-250.

4. Neyra NR, Ikizler TA, May RE, Himmelfarb J, Schulman G, Shyr Y, Hakim RM. Change in access blood flow over time predicts vascular access thrombosis. Kidney Int. 1998;54:17149.

5. Singh N, Ahmad S, Wienckowski JR, Murray BM. Comparison of access blood flow and venous pressure measurements as predictors of arteriovenous graft thrombosis. J Vasc Access. 2006;7:66-73.

6. NKF-K/DOQI: Clinical Practice Guidelines for Vascular Access, update 2006 American Journal of Kidney Diseases, Volume 48, Issue, Supplement S1 (July 2006) pages S176S2471.

7. Tordoir J, Canaud B, Haage P, Konner K, Basci A, Fouque D, Kooman J, Martin-Malo A, Pedrini L, Pizzarelli F, Tattersall J, Vennegoor M, Wanner C, Ter Wee P, Vanholder R. EBPG on Vascular Access. Nephrol Dial Transplant. 2007 May;22 Suppl 2:ii88-ii117.

8. Tessitore N, Bedogna V, Poli A, Mantovani W, Lipari G, Baggio E, Mansueto G, Lupo A. Adding access blood flow surveillance to clinical monitoring reduces thrombosis rates and costs, and improves fistula patency in the short term: a controlled cohort study. Nephrol Dial Transplant. 2008;23:3578-3584.

9. Rayner HC, Pisoni RL, Bommer J, Canaud B, Hecking E, Locatelli F, Piera L, BraggGresham JL, Feldman HI, Goodkin DA, Gillespie B, Wolfe RA, Held PJ, Port FK. Mortality and hospitalization in haemodialysis patients in five European countries: results from the Dialysis Outcomes and Practice Patterns Study (DOPPS). Nephrol Dial Transplant. 2004;19:108-20.

10. Manns B, Tonelli M, Yilmaz S, Lee H, Laupland K, Klarenbach S, Radkevich V, Murphy B. Establishment and maintenance of vascular access in incident hemodialysis patients: a prospective cost analysis. J Am Soc Nephrol 2005;16:201-209.

11. Stengel B, Billon S, Van Dijk PC, et al. Trends in the incidence of renal replacement therapy for end-stage renal disease in Europe, 1990-1999. Nephrol Dial Transplant (2003) 18:18241833.

12. Wakai K, Nakai S, Kikuchi K, et al. Trends in incidence of end-stage renal disease in Japan, 1983-2000: age-adjusted and age-specific rates by gender and cause. Nephrol Dial Transplant 2004;19:2044-2052.

13. Tonelli M, James M, Wiebe N, Jindal K, Hemmelgarn B. Ultrasound monitoring to detect access stenosis in hemodialysis patients: a systematic review. Am J Kidney Dis. 2008:51:630-640.

14. Casey ET, Murad MH, Rizvi AZ, Sidawy AN, McGrath MM, Elamin MB, Flynn DN, McCausland FR, Vo DH, El-Zoghby Z, Duncan AA, Tracz MJ, Erwin PJ, Montori VM. Surveillance of arteriovenous hemodialysis access: a systematic review and meta-analysis. $J$ Vasc Surg. 2008;48:48S-54S.

15. Hoeben H, Abu-Alfa AK, Reilly RF, Aruny JE, Bouman K, Perazella MA. Vascular access surveillance: evaluation of combining dynamic venous pressure and vascular access blood flow measurements. Am J Nephrol. 2003;23:403-408.

16. Lok CE, Bhola C, Croxford R, Richardson RM. Reducing vascular access morbidity: a comparative trial of two vascular access monitoring strategies. Nephrol Dial Transplant. 2003;18:1174-1180.

17. McCarley P, Wingard RL, Shyr Y, Pettus W, Hakim RM, Ikizler TA. Vascular access blood flow monitoring reduces access morbidity and costs. Kidney Int. 2001;60:1164-1172. 
18. Ram SJ, Work J, Caldito GC, Eason JM, Pervez A, Paulson WD. A randomized controlled trial of blood flow and stenosis surveillance of hemodialysis grafts. Kidney Int. 2003;64:272280.

19. Sands JJ, Jabyac PA, Miranda CL, Kapsick BJ. Intervention based on monthly monitoring decreases hemodialysis access thrombosis. ASAIO J. 1999;45:147-150.

20. Schwab SJ, Oliver MJ, Suhocki P, McCann R. Hemodialysis arteriovenous access: detection of stenosis and response to treatment by vascular access blood flow. Kidney Int. 2001;59:358-362.

21. Shahin H, Reddy G, Sharafuddin M, Katz D, Franzwa BS, Dixon BS. Monthly access flow monitoring with increased prophylactic angioplasty did not improve fistula patency. Kidney Int. 2005;68:2352-2361.

22. Wijnen E, Planken N, Keuter X, Kooman JP, Tordoir JH, de Haan MW, Leunissen KM, van der Sande F. Impact of a quality improvement programme based on vascular access flow monitoring on costs, access occlusion and access failure. Nephrol Dial Transplant. 2006;21:3514-3519.

23. Tonelli M, Jindal K, Hirsch D, Taylor S, Kane C, Henbrey S: Screening for subclinical stenosis in native vessel arteriovenous fistulae. J Am Soc Nephrol 2001;12:1729-1733.

24. Tessitore N, Lipari G, Poli A, et al: Can blood flow surveillance and pre-emptive repair of subclinical stenosis prolong the useful life of arteriovenous fistulae? A random ized controlled study. Nephrol Dial Transplant 2004;19:2325-2333.

25. Polkinghorne KR, Lau KKP, Saunder A, Atkins RC, Kerr PG: Does monthly native arteriovenous fistula blood flow surveillance detect significant stenosis-A randomized controlled trial. Nephrol Dial Transplant 2006;21:2498-2506.

26. Smits JHM, Van der Linden J, Hagen EC, et al: Graft surveillance: Venous pressure, access flow, or the combination? Kidney Int 2001;59:1551-1558,.

27. van Loon M, van der Mark W, Beukers N, de Bruin C, Blankestijn PJ, Huisman RM, Zijlstra $\mathrm{JJ}$, van der Sande FM, Tordoir JH. Implementation of a vascular access quality programme improves vascular access care. Nephrol Dial Transplant. 2007 Jun;22(6):1628-32.

28. White JJ, Ram SJ, Jones SA, Schwab SJ, Paulson WD. Influence of luminal diameters on flow surveillance of hemodialysis grafts: insights from a mathematical model. Clin J Am Soc Nephrol. 2006;1:972-978.

29. Schneditz D, Fan Z, Kaufman A, Levin NW. Measurement of access flow during dialysis using the constant infusion approach. ASAIO J 1998;44:74-81.

30. Lopot F, Nejedly B, Sulkova S, Blaha J. Comparison of different techniques of hemodialysis vascular access flow evaluation. Int J Artif Organs 2003;26:1056-1063.

31. Short- and long-term functional effects of percutaneous transluminal angioplasty in hemodialysis vascular access. van der Linden J, Smits JH, Assink JH, Wolterbeek DW, Zijlstra JJ, de Jong GH, van den Dorpel MA, Blankestijn PJ. J Am Soc Nephrol. 2002;13:71520.

32. Vesely $T$, Gherardini D, Starostin D, Krivitski N: Preliminary experiences using intravascular blood flow monitor (IBFM) during vascular access angioplasty. J Am Soc Nephrol 1999;10: $221 \mathrm{~A}$.

33. Chang CJ, Ko PJ, Hsu LA, et al. Highly increased cell proliferation activity in restenotic hemodialysis vascular access after percutaneous transluminal angioplasty: Implication in prevention of stenosis. Am J Kidney Dis. 2004; 43:74-84.

34. Hakim R, Himmelfarb J: Hemodialysis access failure: a call to action. Kidney Int. 1998;54:1029-1040.

35. Murphy GJ, White SA, Knight AJ, Doughman T, Nicholson ML. Long-term results of arteriovenous fistulas using transposed autologous basilic vein. Br J Surg 2000;87: 819-823

36. Tordoir JH, Dammers R, van der Sande FM. Upper extremity ischemia and hemodialysis vascular access. Eur J Vasc Endovasc Surg. 2004;27:1-5.

37. van Hoek F, Scheltinga MR, Kouwenberg I, Moret KE, Beerenhout $\mathrm{CH}$, Tordoir JH. Steal in hemodialysis patients depends on type of vascular access. Eur J Vasc Endovasc Surg. 2006;32:710-717. 
38. Henriksson AE, Bergqvist D. Steal syndrome of the hemodialysis vascular access: diagnosis and treatment. J Vasc Access. 2004;5:62-68.

39. Basile C, Lomonte C, Vernaglione L, Casucci F, Antonelli M, Losurdo N. The relationship between the flow of arteriovenous fistula and cardiac output in haemodialysis patients. Nephrol Dial Transplant. 2008;23:282-287.

40. Engelberts I, Tordoir JH, Boon ES and Schreij G. High-output cardiac failure due to excessive shunting in a hemodialysis access fistula: an easily overlooked diagnosis. Am J Nephrology 1995;15;323-326.

41. Kajiwara IS, Kondo J, Matsumoto A. Banding a hemodialysis arteriovenous fistula to decrease blood flow and resolve high output cardiac failure: report of a case. Surgery Today 1994;24: 734-736.

42. Bailey WB, Talley JD. High output cardiac failure related to hemodialysis arteriovenous fistula. J Ark Med Soc 2000;96;340-341.

43. Young PR Jr, Rohr MS, Marterre WF. High-output cardiac failure secondary to a brachiocephalic arteriovenous hemodialysis fistula: two cases. Jr. Am Surg. 1998;64:239-41.

44. MacRae JM, Pandeya S, Humen DP, Krivitski N, Lindsay RM Arteriovenous fistulaassociated high-output cardiac failure: a review of mechanisms. Am J Kidney Dis. 2004;43:e17-22.

45. Maya ID, Allon M. Outcomes of thrombosed arteriovenous grafts: Comparison of stents versus angioplasty. Kidney Int. 2006; 69:934-937.

46. Chan MR, Bedi S, Sanchez RJ, et al. Stent placement versus angioplasty improves patency of arteriovenous grafts and blood flow of arteriovenous fistulae. Clin J Am Soc Nephrol. 2008; 3:699-705.

47. Rotmans JI, Pattynama PM, Verhagen HJ, Hino I, Velema E, Pasterkamp G, Stroes ES. Sirolimus-eluting stents to abolish intimal hyperplasia and improve flow in porcine arteriovenous grafts: a 4-week follow-up study. Circulation. 2005;29;111:1537-1542. 

Summary 



\section{Summary}

Hemodialysis (HD) is an important treatment modality for patients with end stage renal disease (ESRD). A functional vascular access is a prerequisite for HD treatment. Once created, the vascular access should be easy and frequently cannulated, resistant to infection, stenosis and subsequent thrombosis.

However, in clinical practice $25 \%$ of hospital admissions in HD patients are accounted for vascular access malfunction. Eighty percent of vascular access malfunction is related to thrombosis. Logically, timely stenosis detection combined with pre-emptive intervention would result in a thrombosis incidence decrease, which means less patient morbidity, less hospitalisation, fewer complications, less frequent catheter placement, possibly lower costs and quality of life improvement.

This thesis reflects on the importance of the maintenance of the vascular access through access surveillance and its application using online assessment of vascular access flow $(\mathrm{Q} a)$, being the preferred surveillance tool.

The retrospective analysis, described in chapter two, reports the results of a single dialysis unit when Qa surveillance was applied, compared to a period in which conservative surveillance tools were applied, expressed in costs, access thrombosis and access failure. No difference in access loss was found, however the thrombosis incidence declined significantly for both AVF and AVG during the Qa surveillance period. In patients with AVG a highly significant cost reduction was observed, but in patients with AVF the reduction was not significant.

Chapter three reviewed current literature that studied the effect of online Qa surveillance, combined with pre-emptive intervention, when compared to none or alternative surveillance tools, on the effect of thrombosis incidence for both arteriovenous fistula (AVF) and arteriovenous grafts (AVG). Eight trials were identified. A significant overall ( $A V F$ and AVG) decline in thrombosis rate was reported in four studies. Five studies studied AVF and all reported a thrombosis reduction when using Qa surveillance, of which two reductions were statistically significant. AVG were studied five times: one study reported an increase in thrombosis when Qa surveillance was compared to static venous pressure measurement. The other four studies reported a decrease in thrombosis incidence of which one was not significant. All studies reported an increase in radiological procedures. Despite the significant increase in radiological procedures, two studies that analysed costs as well, reported a cost reduction using $\mathrm{Qa}$ surveillance compared to the control group(s).

The major concern with the trials identified is the poor methodological quality. Besides, important differences in implementation of existing guidelines, organisation and appliance of access flow surveillance and pre-emptive intervention, were noticed. 
The major conclusions are that it is currently unproven that the use of online access flow surveillance, when combined with pre-emptive intervention, has a proven benefit for thrombosis reduction and that future large-scale studies with adequate study design, adequate surveillance and intervention protocols and possibly better pre-emptive intervention alternative(s) are necessary.

In chapter four, two online techniques to measure $\mathrm{Qa}$ are compared. The saline dilution technique, considered the reference technique, is a single measurement set-up. Thermodilution to online measure $\mathrm{Qa}$ uses extracorporeal blood temperature sensors, integrated in the dialysis machine. The integration in the dialysis machine creates the possibility to measure numerous patients simultaneously.

The results of both techniques correlated well. However, reproducibility of the thermodilution technique was inferior compared to the saline dilution technique. It is reasonable to assume that a less accurate measurement technique may cause unnecessary intervention, or missing of severe $\mathrm{Q}$ a decline.

The poor results of the thermodilution technique described in chapter four gave rise to perform another comparison, once more between the considered reference technique and an entire new technique, which at that moment was still at a concept state. This new technique, the temperature gradient method (TGM) requires the same extracorporeal blood temperature sensors. Contrary to the saline- and thermodilution technique, the TGM does not require dilution; it only uses the measured step-change in arterial line temperature after line-reversal. The first in-vivo results of this technique are described in chapter five. The comparison showed a high correlation of measurements obtained by the TGM and saline dilution techniques. For both techniques a high reproducibility of subsequent weekly measurements was observed. Differences in reproducibility were not significant. Moreover, the TGM Qa measurement is quick and simple to execute, an improvement compared to prior described thermodilution technique and comparable to the saline dilution technique regarding both accuracy and practice.

Chapter six reflects on a new technique to measure vascular access recirculation in the context of the overall possibilities to detect vascular access stenosis.

Chapter seven describes the relationship between $\mathrm{Qa}$, different types of vascular access and systemic hemodynamics. This prospective observational trial showed that Qa was significantly related to Cardiac Index $(\mathrm{Cl})$ and it was shown that $\mathrm{Cl}$ was higher in patients with upper arm accesses compared to forearm access types. Although only a small minority of patients with high Qa appeared to be in the risk zone for high-output cardiac failure. 
Chapter eight is an integration of the studies in the foregoing chapters. The studies are put in perspective of the current literature. This thesis underlines the importance of surveillance of the hemodialysis vascular access. Hemodynamic related vascular access complications have major impact on dialysis treatment, morbidity and patients' burden. The role of online access flow assessment regarding surveillance seems of importance though little convincing prove towards thrombosis prevention is available.

Hypothetically, causes why there is discrepancy between high sensitivity of online Qa surveillance and poor results regarding outcome are reviewed. One of many causes might be current measurement frequency, in which new techniques imbedded in the dialysis machine might play an important role.

The relation between $\mathrm{Qa}$ and central hemodynamics suggests caution towards the increase of upper arm fistula. Guidelines might help to timely cope with disturbed access related hemodynamics. 

Samenvatting 



\section{Samenvatting}

Patiënten met terminale nierinsufficiëntie zijn afhankelijk van nierfunctie vervangende therapie. Naast niertransplantatie en peritoneaal dialyse is hemodialyse een belangrijk behandelalternatief. Tijdens een hemodialysebehandeling wordt het bloed van de patiënt, door middel van een door een pomp aangedreven extracorporeel circulatiesysteem, door het semi-permeabele membraam van een kunstnier getransporteerd, zodat diffusie van afvalstoffen kan plaatsvinden naar het buiten de fibers stromende dialysaat. Hierbij geldt uiteraard dat de hoeveelheid bloed die langs de kunstnier stroomt recht evenredig is met de klaring van de afvalstoffen. Om een efficiënte behandeling te bewerkstelligen wordt de bloedpompsnelheid van de extracorporele circulatie ingesteld op circa 300 tot $400 \mathrm{ml} / \mathrm{min}$. De voornaamste vereiste om deze behandeling te kunnen uitvoeren is een adequate toegang tot de bloedbaan.

Het liefst wordt in de onderarm van de patiënt een kortsluiting ('shunt' of 'fistel') gecreëerd tussen een slagader (arterie) en een ader (vene) (arterioveneuze fistel $(A V F)$ ). Door de ontstane weerstandsvermindering zal de arteriële bloedstroom gaan toenemen. De vene zal toenemen in diameter en er zal een debiet ontstaan van zo'n 500 tot $1500 \mathrm{ml} / \mathrm{min}$ (remodeling). Door de subcutane ligging van de vene zal deze goed, veilig en frequent te puncteren zijn. Indien de kwaliteit van de aders en slagader in de onderarm niet toereikend is, zijn enkele alternatieven voorhanden, waaronder de arterioveneuze graft (AVG). In dit geval wordt de hierboven beschreven verbinding tussen de ader en slagader gecreëerd door middel van een kunststof vat. Een ander alternatief is een AVF in de bovenarm. leder alternatief heeft zijn specifieke nadelen ten opzichte van de arterioveneuze fistel in de onderarm.

Hoewel een shunt goed bruikbaar is voor de nierfunctievervangende therapie, ontstaat er door de aanleg van een shunt een onnatuurlijke situatie. Ten gevolge van de ongelijke overgang ter hoogte van de verbinding met de arterie en de vene in combinatie met de ontstane onnatuurlijk hoge en turbulente flow is de kans op vaatwandbeschadiging verhoogd. Er kan een vernauwing van het bloedvat (intima hyperplasie) optreden. Intima hyperplasie kan uiteindelijk resulteren in een volledige occlusie van de AVF of AVG, waardoor de continuïteit van de hemodialyse-therapie ernstig verstoord raakt. Naast deze veel voorkomende problematiek kan een adequaat functionerende shunt leiden tot verstoringen in de perifere en centrale hemodynamiek op basis van de lokaal gecreëerde weerstandsvermindering in de bloedsomloop.

Ter voorkoming van deze problematiek is tijdige en objectieve signalering van symptomen van belang, zodat het onderliggend probleem preventief gecorrigeerd kan worden en occlusie, hartfalen en perifere doorbloedingsstoornissen zich minder zullen voordoen. 
Het moment van de dialysebehandeling leent zich uitstekend om de kwaliteit van de vaattoegang te bewaken. Er zijn verschillende bewakingsmogelijkheden, waarvan debiet (access flow)-bepaling van de AVF of AVG de voorkeur verdient volgens de geldende internationale richtlijnen. Met behulp van angiografie kan een eventueel aanwezige vernauwing aangetoond worden. Angiografie is een afbeeldingstechniek waarbij bloedvaten met behulp van contrastvloeistof worden getoond door middel van röntgenfoto's. Een groot voordeel van deze techniek is dat binnen de diagnostische sessie tevens geïntervenieerd kan worden door het inbrengen van een ballonnetje dat met grote druk wordt opgeblazen zodat de vernauwing wordt opgerekt (Percutane Transluminale Angioplastiek (PTA)).

Doelstelling van dit proefschrift:

1. Inzicht verschaffen in de effecten van de toepassing van access flow-meting, gecombineerd met preventieve interventie ten aanzien van occlusie-incidentie en financiële effecten.

2. Alternatieve online access flow-meettechnieken te vergelijken met de referentietechniek. De vergelijking richt zich op de betrouwbaarheid van de meettechnieken en het praktisch gebruik.

3. Bestuderen of er een relatie bestaat tussen de hoogte van de access flow en het type vaattoegang in relatie tot hemodynamische parameters.

In hoofdstuk twee wordt een retrospectieve analyse beschreven. Twee periodes binnen dezelfde dialyse-afdeling werden met elkaar vergeleken. In de eerste periode werd een conservatieve shuntbewaking toegepast en in de aansluitende periode werd access flowbewaking toegepast. Alle shunt onderhoud gerelateerde kosten, shunt thrombose incidentie en shunt levensduur werden vergeleken. Er werd een significante daling geconstateerd van de trombose-incidentie in de periode waarin access flow-bewaking werd toegepast in vergelijking tot de voorgaande periode voor zowel de AVF als de AVG. De kosten voor shuntonderhoud daalden significant voor de AVG in dezelfde periode. De kostendaling voor de AVF was niet significant. Er werd geen verschil in shuntlevensduur tussen beide perioden beschreven.

In hoofdstuk drie wordt een analyse verricht van de tot nu toe beschreven studies die het effect bestudeerd hebben van online access flow-meting gecombineerd met preventieve interventie, op occlusie incidentie, van zowel de AVF als de AVG. Op basis van vooraf geformuleerde zoekcriteria werden acht studies geïncludeerd voor analyse. Vier studies differentieerden niet tussen AVF en AVG . Deze studies constateerden een significante occlusie daling voor alle vier de access flow-cohorten in vergelijking tot de controlegroep. Binnen vijf van de acht studies werd het effect op de AVF occlusieincidentie geanalyseerd. De occlusie-incidentie daalde in alle vijf AVF access flowcohorten, waarvan twee niet significant waren. Binnen de vijf beschreven AVG cohorten 
werd eenmaal een toename en vier maal een afname van de occlusie-incidentie waargenomen, waarvan één niet significant. Alle studies registreerden een toename van het aantal radiologische interventies (PTA) in vergelijking tot de controlegroepen. Ondanks deze toename rapporteerden de twee studies die tevens de financiële effectsortering van de shuntbewaking analyseerden, een kostendaling in vergelijking tot de controlegroep.

Een belangrijk bezwaar van de geïncludeerde studies is de matige methodologische kwaliteit. Daarnaast zijn belangrijke verschillen geconstateerd in het toepassen of zelfs niet toepassen van de bestaande richtlijnen, de organisatie van de access flowbewaking en het toepassen van de radiodiagnostische diagnostiek en interventie.

De analyse van de geïncludeerde studies geeft geen definitief antwoord op de vraag of online access flow-bewaking een bewezen effect heeft op de occlusie-incidentie. Toekomstige studies zijn nodig om tot een definitieve conclusie te komen. Deze studies zullen minimaal moeten voldoen aan de volgende eisen: voldoende geïncludeerde patiënten, adequate opzet van de studie, adequate access flow-bewaking en interventieprotocollen.

Twee verschillende technieken om access flow te meten worden vergeleken in hoofdstuk vier. De belangrijkste aanleiding tot de studie was van praktische aard. De gesuggereerde referentietechniek (gebaseerd op 'saline-dilution') om tijdens de dialysebehandeling de access flow te kunnen bepalen is een 'stand-alone' meetopstelling. Het meetinstrument van de thermodilutietechniek daarentegen is geïntegreerd in het dialyse-apparaat en biedt zo de mogelijkheid om iedere patiënt gelijktijdig te meten.

Er was sprake van een goede correlatie tussen de meetresultaten van beide technieken. De reproduceerbaarheid van de thermodilutietechniek bleek echter inferieur in vergelijking tot de reproduceerbaarheid van de referentietechniek. Daarnaast lag de geregistreerde tijd die nodig was voor het verkrijgen van het meetresultaat vele malen hoger dan die van de referentie techniek.

De matige resultaten van de hierboven beschreven thermodilutietechniek gaven aanleiding tot het verrichten van een nieuwe studie: Een vergelijk tussen de hierboven genoemde gesuggereerde referentietechniek en een nog niet eerder beschreven techniek. Deze nieuwe techniek, de 'Temperature Gradient Method' (TGM), maakt gebruik van dezelfde geïntegreerde meetsensoren als de thermodilutietechniek. In tegenstelling tot de thermodilutietechniek en de referentie techniek, is genoemde techniek niet gebaseerd op dilutie. De TGM maakt alleen gebruik van de arteriële lijntemperatuurverandering na lijnwissel.

De eerste in vivo resultaten van de TGM worden beschreven in hoofdstuk vijf. Een hoge mate van correlatie werd waargenomen tussen de meetresultaten van de TGM en de referentie techniek. De reproduceerbaarheid van de meting was hoog voor ieder afzonderlijke techniek en onderling niet significant verschillend. Bovendien bleek dat het 
verkrijgen van de access flow door middel van de TGM weinig tijd kostte en makkelijk uitvoerbaar was. De TGM is daarmee een verbetering ten opzichte van de thermodilutiemethode en vergelijkbaar met referentietechniek.

Hoofdstuk zes reflecteert op de introductie van een nieuwe techniek om shuntrecirculatie te meten in vergelijking tot alle actuele technieken om shuntbewaking toe te passen.

In hoofdstuk zeven wordt de relatie tussen access flow, verschillende typen vaattoegang en systemische hemodynamische parameters onderzocht. Deze prospectieve observationele studie beschrijft een significante rechtevenredige relatie tussen access flow en de cardiac index. Daarnaast werd aangetoond dat de cardiac index significant hoger is bij patiënten met een bovenarmsshunt in vergelijking tot patiënten met een onderarmsshunt. Een beperkt aantal patiënten met een hoge access flow bevond zich in de risicozone voor het ontwikkelen van high-output hartfalen.

\section{Perspectieven}

De meeste problemen na aanleg van de vaattoegang zijn gerelateerd aan hemodynamische problemen die optreden door de ontstane onnatuurlijk hoge flow condities. Door snelle beschikbaarheid van de hoeveelheid access flow, kan tijdig geanticipeerd worden op toekomstige problemen.

De huidige literatuur levert geen doorslaggevend bewijs voor de rol van access flow evaluatie ten aanzien van het meest voorkomende en meest wezenlijke probleem, occlusie. De tot nu toe beschreven studies bevatten meerdere hiaten betreffende studie opzet, grootte van de studie en het volgen van de bestaande evidence-based richtlijnen. Belangrijke verschillen zijn geconstateerd in de implementatie en organisatie van zowel de access flow bewaking als de radiologische interventie.

Analyse van de beschikbare literatuur laat zien dat een mogelijke oorzaak zou kunnen zijn: de kwaliteit en het effect van de huidige interventie. Toekomstig onderzoek zal zich in belangrijke mate moeten richten op een effectieve en duurzame behandeling van het stenotisch vaattoegangsletsel. Daarnaast is het aannemelijk dat de huidige frequentie van access flow bepaling niet toereikend is. Nieuwe, in het dialyse-apparaat geïntegreerde technieken, zouden een belangrijke rol kunnen spelen bij het verhogen van de meetfrequentie.

Toekomstige studies en de huidige kennis in relatie tot de verwachte toename in bovenarmsfistels zullen hopelijk resulteren in richtlijnen voor tijdige detectie van problemen ten aanzien van hemodynamische verstoringen (zowel centraal als perifeer). Access flow is een belangrijke hemodynamische parameter en zal, naast stenose detectie, ook een belangrijk middel zijn voor tijdige signalering van distale ischemie en cardiale decompensatie. 
Dankwoord 



\section{Dankwoord}

Geen enkel onderzoek is mogelijk zonder de hulp en inspanning van velen. Bij deze wil ik dan ook allen bedanken die een rol hebben gehad in de totstandkoming van dit proefschrift. Maar er zijn enkele mensen die ik met name heel speciaal wil bedanken voor hun hulp.

Patiënten hemodialyse azM. Haast verbaasd was ik meestal over de getoonde bereidheid om mee te willen werken aan het onderzoek. Ook wanneer ik onbekende onderzoekers introduceerde die aan $\mathrm{u}$ kwamen meten. Ik dank $\mathrm{u}$ allen voor de medewerking en hoop dat de resultaten van dit onderzoek een kleine bijdrage kunnen leveren aan de kwaliteit van uw behandeling.

Dr. van der Sande. Ergens in de loop van 2004, locatie: koffiekamer afdeling hemodialyse azM. Dr. Frank van der Sande: 'Edwin, heb je even.', waarop ik mee ga naar de gang. 'Hoe zou je het vinden om te promoveren?'. Mijn antwoord: 'Mwoah, is misschien wel interessant'. Ik geloof dat we beiden niet wisten waar we aan begonnen, maar zo ongeveer begon ons gezamenlijk avontuur. Het was een avontuur met pieken en enkele dalen, maar toch ben jij altijd in mij blijven geloven; Frank, jouw vertrouwen, steun, kennis en internationale netwerk zijn van onschatbare waarde geweest bij de totstandkoming van dit proefschrift.

Dr. Tordoir. Beste Jan, jouw persoon, jouw vakidiotie en wereldfaam zijn zeer aanstekelijk en medebepalend geweest voor mijn aantrekking tot 'vascular access'. Je openheid voor nieuwe ideeën en het feit dat je altijd bereikbaar was voor praktische suggesties, maakten onze samenwerking een waar genoegen. Je bijdrage aan de slotfase van dit manuscript was bijzonder waardevol. Bedankt!

Professor dr. Leunissen. Beste Karel, ondanks je overvolle agenda gecombineerd met je lidmaatschap van de Eerste Kamer, heb ik altijd steun en vertrouwen ervaren, waarvoor dank.

Leden van de beoordelingscommissie. Onder aanvoering van Prof. dr. L. Hofstra hebben Prof. dr. A.C. van der Vusse, Prof. dr. P.M. Ter Wee en Dr. M.R. Scheltinga op kundige wijze het manuscript beoordeeld, waarvoor dank.

Dr. Kooman. Het eerste concrete fundament van dit proefschrift was er niet zonder jou, Jeroen. Ik zal jouw razendsnelle analyses en essentiële suggesties in de slotfase van een manuscript niet snel vergeten. 
Renee Senden. Je hebt me wegwijs gemaakt tijdens mijn eerste jaar op de dialyseafdeling. Mede daardoor deelde ik al gauw met jou een gezamenlijke interesse voor vaattoegang.

Magda van Loon. En toen was daar opeens Magda! Het o.a. door jou en de Nierstichting geïnitieerde nationale vaattoegangskwaliteitsproject bracht ons met elkaar in contact. Jouw enthousiasme werkte zeer aanstekelijk. Jij hebt me helpen grenzen durven te verleggen en daarmee competenties laten verwerven, die later onontbeerlijk bleken te zijn tijdens mijn promotietraject. Ook tijdens mijn promotietraject was je een belangrijke sparringpartner, steun en toeverlaat. Ik ben enorm blij en trots dat jij mij terzijde staat tot aan het einde; hora est. Succes met jouw promotie!

Ger van Meijel. Jij hebt me geholpen in het maken van een belangrijke keus, die later een belangrijke stap bleek te zijn richting het promoveren. Samen hebben we de propedeuse biometrie aan de hogeschool Zuyd doorlopen en onze gezamenlijke eindopdracht voor deze opleiding bleek 'zomaar' goed te zijn voor een wetenschappelijke publicatie.

Dr. Schneditz. Dear Danny, without you, no TGM! After intensive cooperation through mail it is regretful we have never met. You were always quick in response to my numerous questions and your answers were always thorough and meaningful. Thank you!

Stig en Thijs. Het was leuk om jullie wegwijs te maken in de verschillende manieren om flow te meten. Bedankt voor jullie toewijding, enthousiasme en gezellige momenten. Succes met jullie verdere carrière.

Mijn collega's dialyse verpleegkundigen. Beste collega's, jullie hebben wat doorstaan met mij. Als fulltime dialyseverpleegkundige hield ik me bezig met studie, allerlei wetenschappelijke neventaken en heb ik heel wat congressen bezocht binnen en buiten werktijd. Toch heb ik de nodige steun ervaren en ik dank jullie voor de negen jaren dat wij hebben samengewerkt.

Vaatlab en röntgen. Alle mensen van het vaatlab en de 'angiokamer', bedankt voor de samenwerking! Jacques, bedankt voor alle "data-voer" en Michiel de Haan voor het gebruik mogen maken van je expertise. 
Piet en Paul, bedankt voor jullie interesse, de technische ondersteuning en het kritisch meedenken.

Tiny Wouters. Beste Tiny, het was aangenaam kennis met iemand te maken die zomaar een smak werk van mij overnam. Ook was je kritisch en gaf je goede feedback. Bedankt hiervoor en voor alle werk aan de lay-out van het proefschrift.

Fons Kessels, bedankt voor je waardevolle consult inzake de ICC.

Gemma Has, bedankt voor het redigeren van de Nederlandse teksten.

Nils en Xavier, ik vond het erg fijn dat we e.e.a. hebben kunnen delen. Berlin was hot!

Tom Bijl. Lieve Tommie, jij hebt me begeleid tijdens mijn laatste HBO-V stage en mijn eerste half jaar als kersverse verpleegkundige. Onze carrièrepaden liepen vervolgens niet simultaan, maar onze vriendschap is gebleven. Ik ben enorm trots dat jij mij terzijde staat.

Professor de Wit. Beste Rianne, bedankt voor het meedenken over het opzetten van een systematische meta-analyse.

Vrienden, familie en bekenden. Bedankt voor alle interesse en schouderklopjes.

Lieve mama, papa en Marjolein. Wie had dat kunnen denken, een promovendus binnen de familie. Zonder jullie was dit boekje echter nooit geschreven. Bedankt voor die zeer belangrijke basis en alle steun tijdens de afgelopen periode.

Ook wil ik mijn grote en waardevolle schoonfamilie en in het bijzonder Rob en Ria bedanken voor alle vertrouwen, interesse, begrip en warmte. Fijn dat we er altijd voor elkaar zijn.

Lieve Lin, de eindstreep is in zicht. Het schrijven van een proefschrift doe je niet alleen en voor zo'n inspanning moet aan heel wat randvoorwaarden voldaan worden. Het was niet makkelijk, maar ongelooflijk wat jij met mij en onze twee lieve kinderen voor mekaar gekregen hebt... Hou van jou!

Simon en Sofie. Nog even en dan is 'moet je weer studeren papa?', eindelijk geen vraag meer die jullie vaak zullen moeten stellen. Als jullie eens wisten hoe vaak jullie mij hebben verblijd met jullie afleidingsmanoeuvres. Hou van jullie! 

Curriculum vitae 



\section{Curriculum vitae}

De auteur werd op 1 maart 1974 geboren te Heerlen. In 1993 behaalde hij het Atheneum diploma aan het Sint-Janscollege te Hoensbroek waarna gestart werd met de HBO opleiding Verpleegkunde aan de Hogeschool Limburg te Sittard. In 1997, het jaar van diplomering, startte hij als verpleegkundige binnen de afdeling algemene interne / neurologie van het voormalige St. Jozefziekenhuis te Kerkrade. Na eerst nog in het voormalige Maasland Ziekenhuis te Sittard gewerkt te hebben, zette hij in 1998 zijn verpleegkundige carrière voort in het academisch ziekenhuis Maastricht, waar hij tot april 2000 werkte binnen de verpleegafdeling neurologie en aansluitend tot september 2009 binnen de afdeling hemodialyse.

$\mathrm{Na}$ in 2001 zijn opleiding tot dialyse verpleegkundige afgerond te hebben, startte hij in 2003 met de duale HBO opleiding biometrie (propedeuse) aan de Hogeschool Zuyd, te Heerlen, welke hij afrondde in 2004. Aansluitend werd in 2005 gestart met onderzoek naar de rol en mogelijkheden van online flow bewaking bij de toegang tot de bloedbaan voor hemodialyse.

Hij heeft lezingen gegeven op verschillende nationale en internationale congressen, waarvan twee op uitnodiging (EDTNA/ERCA conference, Madrid, 2006. Gfn Kongress, Göttingen 2009). Twee maal zijn de door hem ingezonden originele abstracts verkozen tot 'best nursing abstract' van de Annual Dialysis Conference; Tampa, Florida 2005 en Denver, Colorado 2007.

Momenteel volgt hij de master 'advanced nursing practice' aan de Hogeschool Zuyd te Heerlen en is hij werkzaam als verpleegkundig specialist in opleiding binnen Cicero Zorggroep te Brunssum.

Hij is getrouwd met Linda Vreeke. Samen hebben ze een zoon en een dochter; Simon (2004) en Sofie (2007). 
